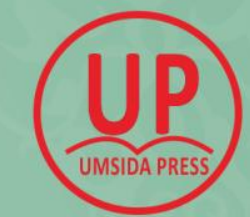

UMSIDA PRESS

Jl. Mojopahit 666 B Sidoarjo

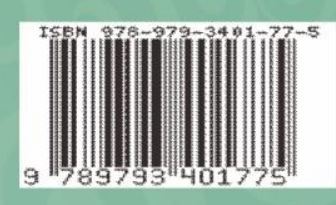

$\frac{\text { v }}{2}$

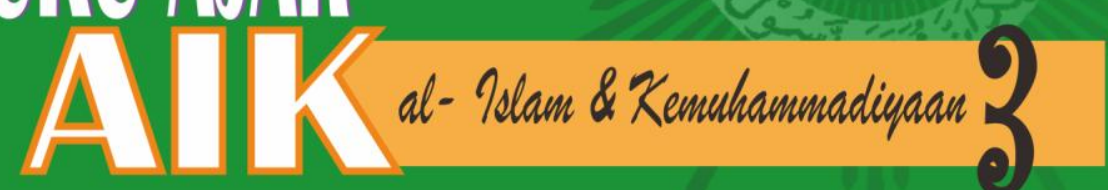
KEMUHAMMADIYAHAN
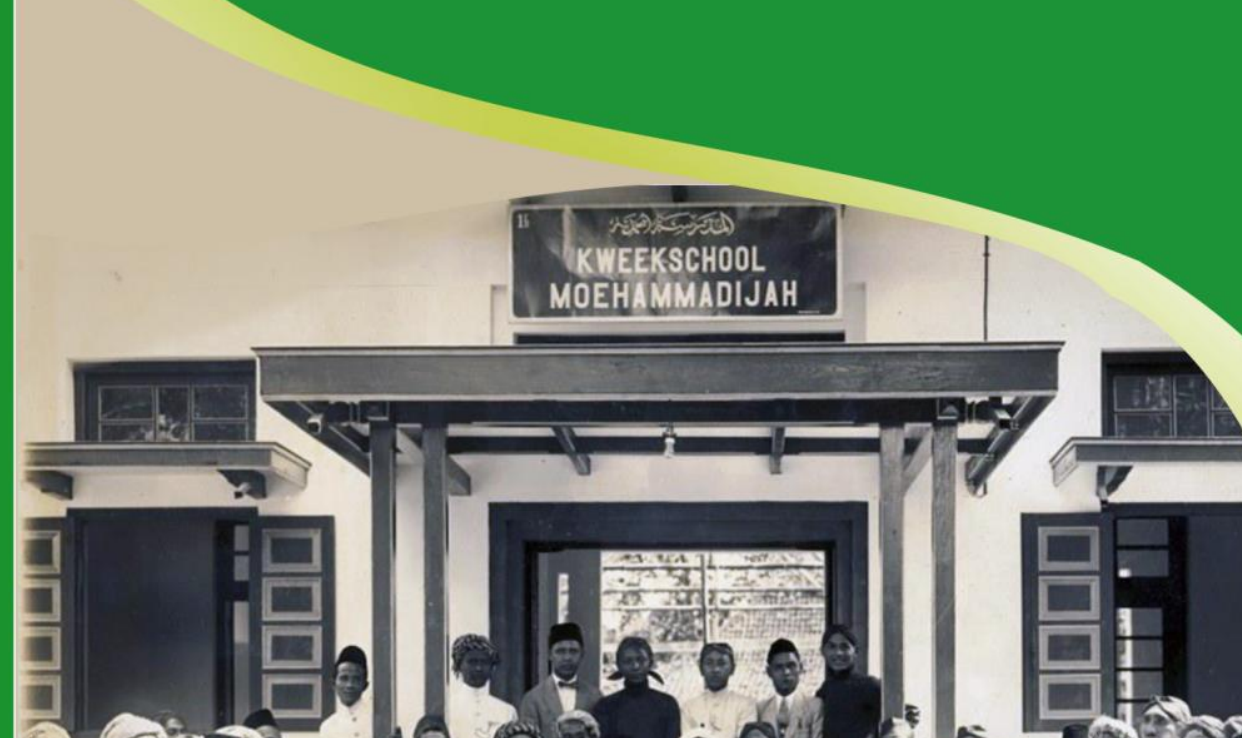

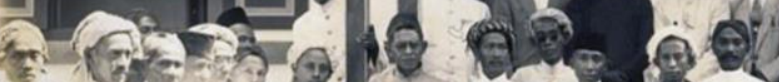
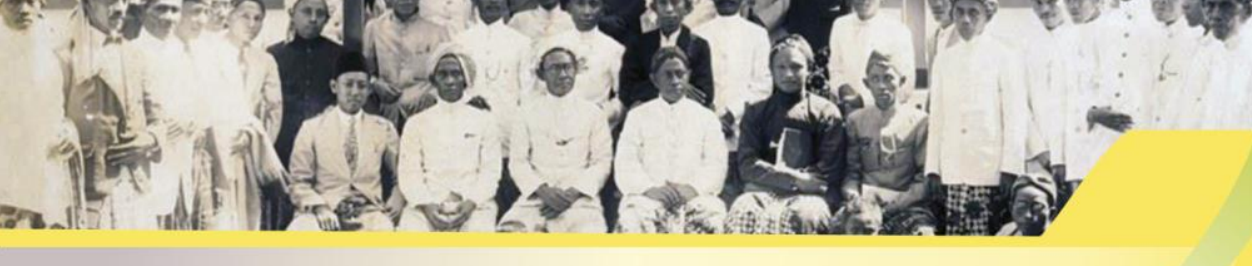

UNIVERSITAS MUHAMMADIYAH 2017 


\section{BUKU AJAR \\ AL-ISLAM DAN KEMUHAMMADIYAHAN - 3 \\ (AIK - 3)}

\section{Penulis}

Puspita Handayani, S.Ag., M.Pd.I

Ima Faizah, SP., M.Pd.I

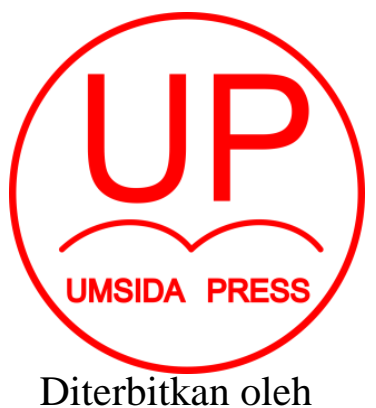

\section{UMSIDA PRESS}

J1. Mojopahit 666 B Sidoarjo

ISBN: 978-979-3401-77-5

Copyright@2017.

Authors

All rights reserved 
BUKU AJAR AL-ISLAM DAN KEMUHAMMADIYAHAN - 3

(AIK - 3)

Penulis :

Puspita Handayani, S.Ag., M.Pd.I

Ima Faizah, SP., M.Pd.I

\section{ISBN :}

978-979-3401-77-5

\section{Editor :}

Puspita Handayani, S.Ag., M.Pd.I

M. Tanzil Multazam, S.H., M.Kn.

Copy Editor :

Fika Megawati, S.Pd., M.Pd.

Design Sampul dan Tata Letak :

Mochamad Nashrullah, S.Pd

\section{Penerbit :}

UMSIDA Press

\section{Redaksi :}

Universitas Muhammadiyah Sidoarjo

J1. Mojopahit No 666B

Sidoarjo, Jawa TImur

\section{Cetakan pertama, Agustus 2017}

(C) Hak cipta dilindungi undang-undang

Dilarang memperbanyak karya tulis ini dengan suatu apapun tanpa ijin tertulis dari penerbit. 


\section{KATA PENGANTAR}

Alhamdulillah dengan memanjatkan rasa syukur kepada Allah SWT, yang atas izin dan pertolonganNya semata, akhirnya buku ajar Al-Islam dan Kemuhammadiyahan 3 bisa tersusun. Penyajian buku ajar AIK 3 ini disusun dalam rangka memberikan wawasan kepada mahasiswa tentang materi dasar kemuhammadiyahan, meliputi: sejarah, ideologi, , muhammadiyah sebagai gerakan Islam, sosial, pendidikan dan pemberdayaan perempuan, serta pedoman hidup Islami. Bagaimana Muhammadiyah dalam peran kebangsaan.

Sidoarjo, 10 Maret 2017

Penulis 


\section{DAFTAR ISI}

Kata Pengantar

Daftar Isi.

BAB I PEMURNIAN DAN PEMBAHARUAN DI DUNIA ISLAM
A. Pendahuluan
B. Menjelaskan kemajuan peradaban Islam ................................. 1
C. Menjelaskan sebab-sebab kemundurannya .............................. 13
D. Menjelaskan perlunya pemurnian dan pembaharuan.................... 16
E. Menjelaskan tokoh pembaharuan dalam dunia Islam .................. 21

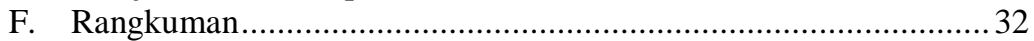
G. Soal latihan ................................................................... 33

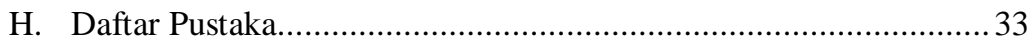

BAB II DAKWAH ISLAM NUSANTARA
A. Pendahuluan 34
B. Teori masuknya Islam Nusantara ...................................... 35
C. Corak Islam Nusantara .................................................. 40
D. Hubungan Kedatangan Penjajah dan penyebaran Islam Nusantara ............................................................. 42
E. Rangkuman................................................................... 45

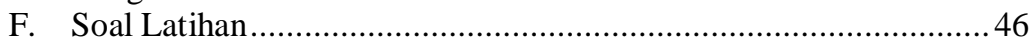
G. Daftar Pustaka................................................................ 47

BAB III SEJARAH BERDIRINYA MUHAMMADIYAH
A. Pendahuluan 48
B. Faktor Obyektif dan Subyektif berdirinya Muhammadiyah .......... 49
C. Profil K.H. Ahmad Dahlan..................................................... 55
D. Pemikiran K.H Ahmad Dahlan tentang Islam dan Umatnya ..........60 60

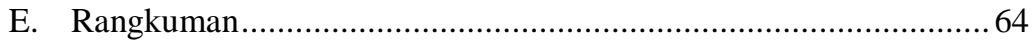

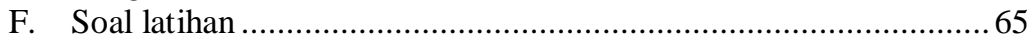
G. Daftar Pustaka................................................................ 65

\section{BAB IV KEPRIBADIAN MUHAMMADIYAH}

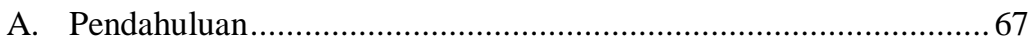

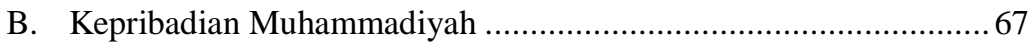
C. Sejarah Perumusan Kepribadian Muhammadiyah........................69 69
D. Matan (Teks) Kepribadian Muhammadiyah....................... 70
E. Pedoman amal usaha dan perjuangan Muhammadiyah ................ 72
F. Sifat-sifat Muhammadiyah ............................................. 72 


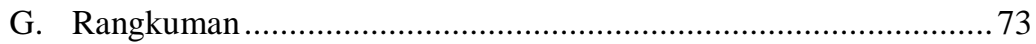

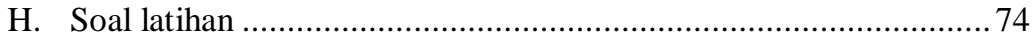

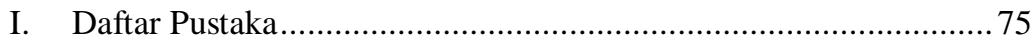

BAB V MATAN KEYAKINAN DAN CITA-CITA HIDUP MUHAMMADIYAH

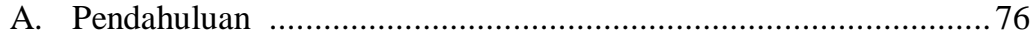

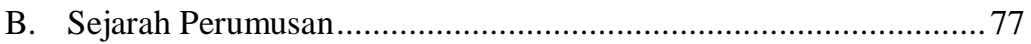

C. Identitas dan Asas Muhammadiyah ............................................... 81

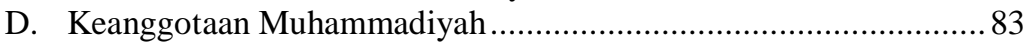

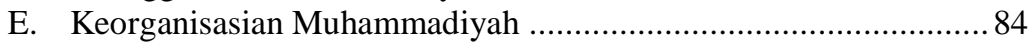

F. Pemikiran dan gerakan Muhammadiyah dalam bidang Akidah, Ibadah, Akhlak dan mu'amalah................................................. 86

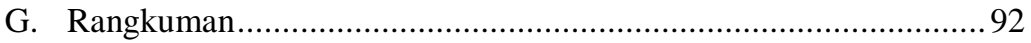

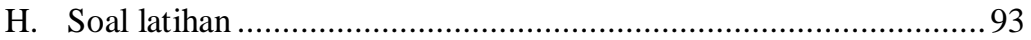

I. Daftar Pustaka.............................................................................. 94

\section{BAB VI MUHAMMADIYAH SEBAGAI GERAKAN}

\section{TAJRID DAN TAJDID}

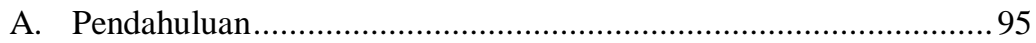

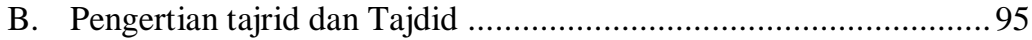

C. Model Tajrid dan tajdid Muhammadiyah......................................97

D. Model dan maknagerakan keagamaan

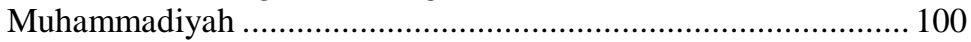

E. Gerakan tajdid pada 100 tahun pertama dan

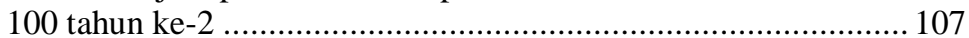

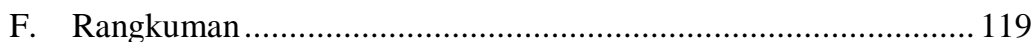

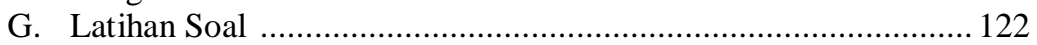

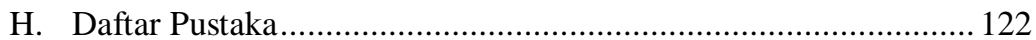

BAB VII MUHAMMADIYAH SEBAGAI GERAKAN SOSIAL

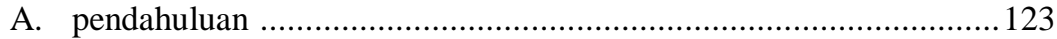

B. Teologi Al-Ma'un (ajaran sosial kemanusiaan Muhammadiyah) ....124

C. Bentuk dan gerakan kemanusiaan Muhammadiyah ........................ 127

D. Revitalisasi Gerakan Sosial Muhammadiyah ................................... 128

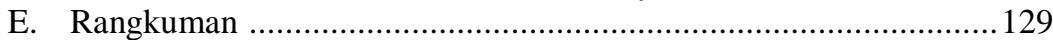

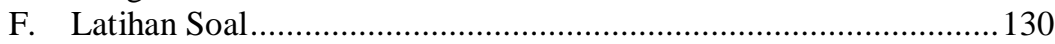

G. Daftar Pustaka............................................................................ 130

\section{BAB VIII MUHAMMADIYAH SEBAGAI GERAKAN PENDIDIKAN}

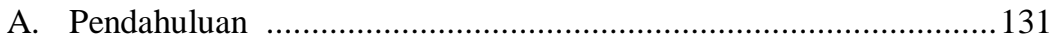

B. Faktor melatar belakangi Gerakan Muhammadiyah dalam Pendidikan 
C. Cita-Cita Pendidikan Muhammadiyah ......................................... 133

D. Menjelaskan Bentuk dan Model Pendidikan Muhammadiyah......... 136

E. Filsafat Praktis Gerakan Pendidikan Muhammadiyah.....................137

F. Tantangan dan Revitalisasi Gerakan Pendidikan Muhammadiyah

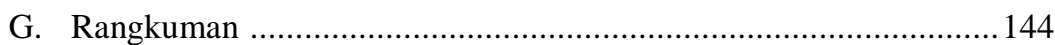

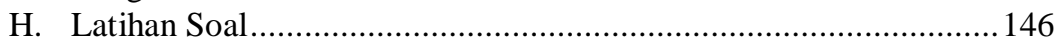

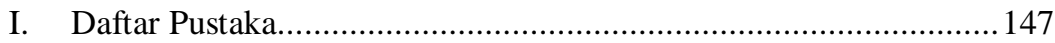

BAB IX MUHAMMADIYAH DAN GERAKAN PEMBERDAYAAN PEREMPUAN

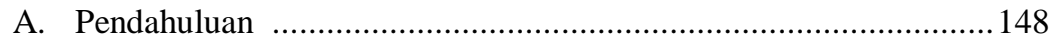

B. Cara KH. Ahmad Dahlan dalam Pemberdayaan Perempuan .......... 149

C. Kesetaraan Gender Dalam Muhammadiyah................................... 152

D. Peran Perempuan Muhammadiyah dalam Kehidupan Berbangsa

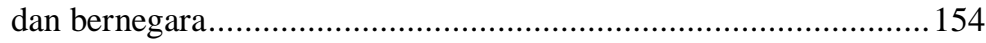

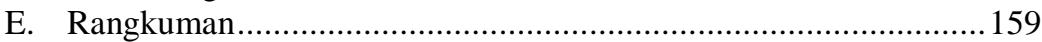

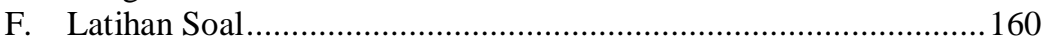

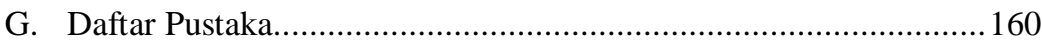

BAB X MUHAMMADIYAH SEBAGAI GERAKAN EKONOMI

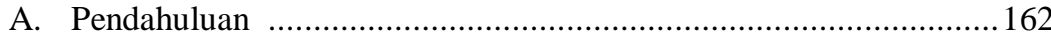

B. Prinsip Ekonomi dalam Muhammadiyah.................................... 162

C. Pasang surut Gerakan Ekonomi Muhammadiyah............................ 164

D. Bentuk dan Model gerakan Ekonomi Muhammadiyah ..................... 166

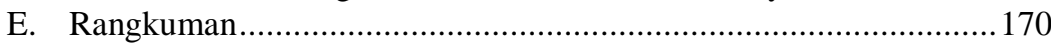

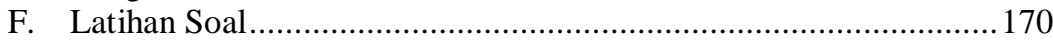

G. Daftar Pustaka............................................................................... 171

\section{BAB XI PERAN KEBANGSAAN MUHAMMADIYAH DI} INDONESIA

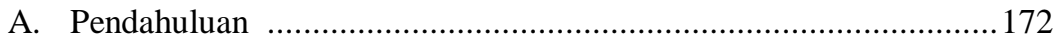

B. Khittah Muhammadiyah dalam Berbangsa dan bernegara ..............173

C. Muhammadiyah sebagai Pendiri NKRI ........................................ 179

D. Tanggungjawab Muhammadiyah terhadap bentuk dan model Peran kebangsaan Muhammadiyah ............................................. 181

E. Bentuk dan Model Peran Kebangsaan Muhammadiyah ................... 183

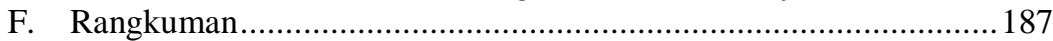

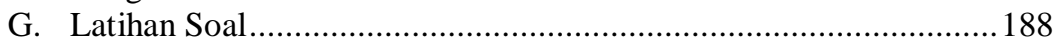

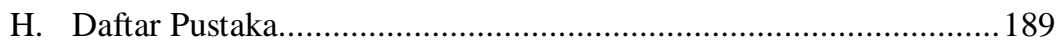

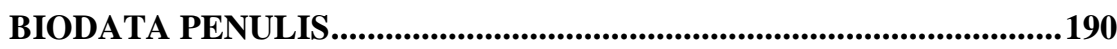




\section{BAB I}

\section{PEMURNIAN DAN PEMBAHARUAN DI DUNIA ISLAM}

Nama Mata Kuliah

Semester

SKS

Pertemuan ke-

Lama Jam pertemuan
: AIK 3 (KE-MUHAMMADIYAH-AN)

: III

: 2 sks

: 1 (satu)

: $2 \times 50$ menit

Kemampuan akhir yang diharapkan:

1.1. Memahami kemajuan peradaban Islam

1.2. Memahami sebab-sebab kemundurannya

1.3. Memahami perlunya pemurnian dan pembaharuan

1.4. Memahami tokoh pembaharu dalam dunia Islam

\section{A. PENDAhuluan}

Pada Bab ini akan dijelaskan tentang kemajuan peradaban islam, sebab-sebab kemunduran Islam, Pemurnian dan Pembaharuan, serta mengetahui tokohtokoh Pembaharuan di dulnia Islam.

\section{B. KEMAJUAN PERADABAN ISLAM}

Sekitar abad VII sampai dengan abad X Masehi, Islam berkembang dengan pesatnya, meliputi wilayah-wilayah yang sangat luas dengan penguasaan ilmu pengetahuan, peradaban, dan kebudayaan yang sangat maju dan tinggi. Kejayaan Islam ini merupakan hasil perjuangan yang tidak mengenal lelah, baik yang dirintis dan dipelopori oleh Rasulullah SAW beserta para 
sahabatnya, diteruskan pada zaman Khulafaur Rasyidin, dinasti Umaiyah, dinasti Abbasiyah, dinasti Umaiyah Andalusia, dan dinasti Fathimiyah.

a. Dinasti Umaiyah (661-750 M)

Kekhalifahan Umaiyah dimulai dengan naiknya Mu'awiyah sebagai khalifah yang pertama kali dari dinasti Umaiyah pada tahun $661 \mathrm{M}$. Pada periode ini wilayah kekuasaan Islam semakin bertambah luas. Dari Afrika Utara, sebagian India, Afganistan, Turkistan, Samarkan, dan sebagian besar Kerajaan Rumawi Timur. Sukses yang diraih oleh Islam dalam memperluas wilayah kekuasaannya seperti itu tidak lain karena Islam sangat menekankan etika hidup dalam segala hal, termasuk ketika melakukan ekspansi kekuasaannya. Gustav le Bon, seorang cendekiawan, sejarawan dan filosof Prancis menyatakan bahwa "sejarah tidak pernah mengenal sang penakluk yang lebih adil dan lebih santun, kecuali Islam". ${ }^{1}$

Dalam rentang sejarah kekhalifahan Umaiyah yang panjang, tercatat adanya upaya pengembangan ilmu pengetahuan yang pesat. Di antaranya didirikannya perguruan tinggi seperti Universitas Iskandariyyah dan Universitas Naisabur sebagai pusat penelitian dan pengembangan ilmu

\footnotetext{
${ }^{1}$ Musthafa Kamal Pasha \& Ahmad Adaby Darban, Muhammadiyah
} Sebagai Gerakan Islam,(Yogyakarta: Pustaka SM, 2009), 3 
pengetahuan. Di universitas ini dipelajari dan diterjemahkan berbagai bidang keilmuan yang berasal dari Yunani, seperti ilmu kedokteran, kimia, filsafat, astronomi, dan lain-lain. Pada masa ini pula muncul tokoh-tokoh mujtahid besar dalam bidang fikih, seperti Imam Abu Hanifah an-Nu'man $(80-150 \mathrm{H})$ yang terkenal sebagai penumbuh madzhab Hanafi, Imam Malik bin Anas (meninggal $179 \mathrm{H}$ ), dikenal sebagai penyusun Kitab Muwaththa' dan penumbuh madzhab Maliki, imam Muhammad Idris as-Syafi'i (105-204 $H$ ), penyusun Kitab al-Umm dan penumbuh madzhab Syafi'i, dan imam Ahmad bin Muhammad bin Hanbal (164-241 H), penumbuh madzhab Hanbali.

b. Dinasti Abbasiyah (750-1258 M)

Periode dinasti Abbasiyah ditandai dengan dikalahkannya kekuasaan Umaiyah yang berpusat di kota Damaskus (Syiria) oleh Abul 'Abbas as-Saffah, dari keturunan 'Abbas bin 'Abdul Muthalib (salah seorang dari paman Nabi Muhammad SAW). Kekuasaan dinasti Abbasiyah berlangsung sekitar 509 tahun dengan Baghdad, Irak sebagai pusat kekhalifahannya.

Di antara sekian khalifah dari bani Abbasiyah tercatat namanama khalifah yang besar sekali jasanya dalam pengembangan ilmu pengetahuan dan peradaban Islam. 
Mereka adalah Abu Ja'far al-Mansur dan Harun al-Rasyid. Pada masa khalifah Abu Ja'far al-Mansur (755-775 M), ia dengan kerasnya mendorong para cendekiawan di samping untuk menyusun buku-buku ilmiah, juga untuk menerjemahkan berbagai buku Yunani kuno, terutama buku filsafat yang hampir tidak lagi dikenal oleh masyarakat. Pemerintah menjanjikan bagi siapapun yang berhasil menyalin (menterjemahkan) buku-buku tersebut, baik yang disalin ke dalam bahsa Arab maupun bahasa Parsi, tanpa membeda-bedakan latar belakang agama dan kepercayaan yang dianutnya, kepada mereka diberikan imbalan (royalty) yang sangat menggiurkan, yaitu berupa emas murni seberat timbangan buku hasil terjemahan mereka.

Sebagai bukti yang menunjukkan betapa gairahnya Negara mendukung perkembangan ilmu pengetahuan adalah pada tahun $981 \mathrm{M}$ di sepanjang sungai Tigris yang membelah kota Baghdad telah terdapat sekitar 100 perpustakaan, yang terbesar adalah Darul Hikmah, yang berisi berbagai macam buku, baik asli maupun terjemahan, dilengkapi pula dengan ruangan khusus untuk berdiskusi. Demikian pula bangunan gedung pendidikan, baik untuk tingkat dasar, menengah, maupun perguruan tinggi ada di mana-mana. Di 
Baghdad juga terdapat gedung observatorium bintang guna mengamati benda-benda langit.

Dalam tempo kurang lebih 50 tahun setelah membangun dinasti Abbasiyah, sebagian besar sektor ilmu pengetahuan telah dibukukan, baik yang berkenaan dengan ilmu naqliyah, seperti ilmu-ilmu al-Qur'an, ilmu Hadits, ilmu Tauhid, Fiqh, maupun ilmu-ilmu aqliyah yang diambil dari peradaban kuno, seperti matematika, astronomi, logika, kedokteran, filsafat, fisika, kima, dan sebagainya. Perkembangan dinasti Abbasiyah mencapai titik puncaknya pada masa pemerintahan Khalifah Harun al-Rasyid (786809 M).

Dalam suasana semaraknya perkembangan ilmu pengetahuan dunia Islam, lahirlah ilmuwan muslim, diantaranya:

1. Al-Kindi, seorang filosof Islam pertama, sekaligus seorang dokter, ahli optika, astronomi, geometri, dan ahli musik. la telah menjadi penghafal al-Qur'an pada usia 10 tahun. Dalam "The Legacy of Islam" dikatakan bahwa buku tentang optika yang dikarangnya diterjemahkan dalam bahasa Latin, dan banyak mempengaruhi pemikiran Roger Bacon.

2. Al-Farabi, dijuluki sebagai seorang filosof Islam yang terbesar di abad X. Para ahli filsafat Islam memberikan 
gelar 'Guru Kedua' kepadanya karena jasa-jasanya dalam bidang logika. Dan karena ilmu logikanya itu pula ia dianggap sebagai filosof tulen, par excellence, atau murni.

3. Ibnu Sina (Avicenna), seorang filosof dan ahli kedokteran yang sangat terkenal. Karyanya di bidang kedokteran berupa buku 'al-Qanun fi al-Tib' atau lebih dikenal dengan 'The Canon'. Buku ini oleh dunia Barat disalin ke dalam bahasa Latin dan bahasa Eropa lainnya, serta dijadikan buku rujukan di berbagai perguruan tinggi Barat. Sedangkan sebagai filosof ia mengarang buku "AsSyifa'” yang juga diterjemahkan ke dalam bahasa Latin oleh Ibnu Daud di Toledo.

4. Abu Ali al-Hasan (al-Hazen) terkenal dengan banyak sumbangannya pada bidang ilmu kimia.

5. Ibnu Daud al-Khawarizmi adalah perintis ilmu matematika, yang kelak akan berkembang menjadi aljabar dan algoritma.

6. Jabir Abu Musa ibnu Haiyan yang dikenal sebagai pengembang ilmu Kimia, hingga ia dijuluki sebagai Bapak Ilmu Kimia.

7. Al-Biruni, seorang saintis muslim yang serba bisa. la dikenal sebagai ilmuwan bidang matematika, fisika, kedokteran, astronomi, filsafat, dan ahli sejarah yang 
luar biasa. Bukunya yang sangat terkenal adalah 'Tarikhul Hindi', yang oleh Seyyed Hossein Nasr dalam bukunya 'Science and Civilization in islam' (1968) dikatakannya buku yang paling lengkap uraiannya dan terbaik mengenai agama Hindu, sains dan adat istiadat India.

Selain itu ada pula beberapa tokoh di bidang tasawuf yang tidak dapat dipungkiri kemasyhuran dan perannya dalam perkembangan ilmu Islam seperti Zunnun al-Misriy yang terkenal dengan faham ma'rifah, Husein Ibnu Mansur al-Hallaj yang terkenal dengan aliran Hulul, Abdul Karim alJili, Abu Hamid Muhammad al-Ghazali dengan kitabnya 'Ihya' Ulum al-Din', serta Rabi'ah al-Adawiyah yang dikenal sebagai pelopor aliran Mahabbah.

Kota Baghdad benar-benar menjadi kota yang diterangi dengan berbagai ilmu pengetahuan dan peradaban yang sangat tinggi, yang kehangatan sinarnya memancar ke seluruh penjuru dunia belahan timur. Baghdad ketika itu identik dengan kota ilmu pengetahuan dan kota peradaban yang didatangi para pencari ilmu dari berbagai penjuru dunia.

Dari segi pengembangan ekonomi, pada masa ini terjadi perluasan perdagangan dan perniagaan Islam yang didominasi oleh perdagangan barang-barang mewah, seperti 
wangi-wangian, perhiasan, logam mulia, sutera. Di bidang industri yang paling utama adalah tekstil yang telah dimulai pada periode Umayyah dan kini meluas dengan pesatnya. Segala macam barang telah dapat dihasilkan seperti pakaian, karpet, permadani dinding, bahan pembungkus perabot, dan lain-lain. Pelabuhan di sekitar Baghdad ramai oleh hilir mudiknya berbagai macam kapal mancanegara yang datang silih berganti untuk membawa dagangannya, yang semua itu mencerminkan betapa tingginya kesejahteraan dan kemakmuran daulah Abbasiyah.

c. Dinasti Umaiyah di Andalusia-Spanyol (757-1492 M)

Kekhalifahan ini diawali dengan kedatangan pasukan Islam ke daratan Spanyol di bawah pimpinan Thariq bin Ziyad pada tahun $711 \mathrm{M}$, yang ditandai dengan ditaklukkannya kerajaan Visigoth yang diperintah oleh raja Roderick. Namun, kehalifahan ini baru berdiri pada tahun $757 \mathrm{M}$, ketika Abdur Rahman ad-Dakhil - satu-satunya orang dari dinasti Umaiyah yang berhasil melarikan diri dari pertempuran antara daulah Umaiyah dan Abbasiyah memegang kendali kekuasaannya dengan Cordova sebagai pusat pemerintahannya.

Dalam hubungannya dengan kehidupan masyarakat, kini di tengah-tengah masyarakat Spanyol setidaknya terdapat dua 
ras, yaitu Arab dan Spanyol. Setelah melewati adaptasi yang relatif singkat terjadilah proses asimilasi antara keduanya yang kemudian menghasilkan generasi campuran, yaitu bangsa Moor. Bangsa Moor inilah yang kemudian menguasai daulah Umaiyah di Andalusia selama tujuh setengah abad.

Seperti halnya dinasti Abbasiyah yang menaruh perhatian sangat besar terhadap perkembangan ilmu pengetahuan, peradaban, dan kebudayaan, pemerintahan Andalusia di bawah kekuasaan Khalifah al-Hakam II al-Mustanshir juga melakukan hal yang tidak kalah besar. Khalifah ini telah mengeluarkan biaya yang sangat besar untuk mendorong pertumbuhan ilmu pengetahuan, antara lain dengan cara membeli buku-buku ilmiah dari Baghdad. Dalam waktu yang tidak terlalu lama Cordova mulai dikenal oleh masyarakat Eropa sebagai pusat kebudayaan dan pusat ilmu pengetahuan, yang ditandai dengan banyaknya perpustakaan yang sarat oleh berbagai macam buku mengenai berbagai bidang keilmuan sehingga mampu menyaingi Baghdad sebagai pusat Ilmu Pengetahuan di dunia Islam.

Tidak hanya itu, perkembangan peradaban dan kebudayaannya pun dinilai sangat besar. Hal ini ditunjukkan dengan dibangunnya beberapa bangunan megah dengan 
arsitektur yang sangat tinggi dan mengagumkan. Seperti, Istana al-Hambra (al-Hamra' atau merah) di Granada, Masjid Cordova (al-Qurthubi), Kota az-Zahra, dan beberapa bangunan lainnya. Bahkan beberapa bangunan bekas kekuasaan daulah Umaiyah di Andalusia ini oleh pemerintah Spanyol saat ini masih tetap dipelihara dan dijadikan andalan pariwisata yang banyak mendatangkan devisa Negara.

Pada masa dinasti Umaiyah di Andalusia ini telah lahir sekian banyak intelektual muslim, seperti:

1. Ibn Bajjah, yang karyanya dikenal dengan sebutan magnum opus (a great work of art or literature) TADBIR AL-MUTAWAHHID

2. Ibn Tufail, dengan karyanya HAYY IBN YAQDZAN

3. Ibn Rushd (Averoes), yaitu seorang cendekiawan dan filosof Andalusia yang dikenal luas oleh masyarakat Barat. Pengaruhnya dalam filsafat Eropa lebih besar dari pengaruh Ibnu Sina. Tulisannya yang berisi komentarnya terhadap filsafat Aristoteles diterjemahkan dalam bahasa Latin. la juga dikenal sebagai seorang dokter dengan buku karyanya 'Kitabul Kulliyyat' atau 'Colliget'. Dan ia juga seorang ahli fiqh yang karyanya dikenal luas dalam masyarakat Islam, yaitu BIDAYAH AL-MUJTAHID. 
4. Ibnu Khaldun, seorang ahli dalam bidang ilmu Sosial, bahkan ada yang menyebutnya sebagai Bapak Sosiologi. Hasil karyanya yang terkenal hingga saat ini adalah 'Muqaddima' atau 'Introduction of Ibnu Khaldun.

Dalam masalah pengembangan ekonomi, daulah Umaiyah di Spanyol mencapai sukses yang sangat signifikan, demikian halnya dengan sektor industri, seperti pembuatan kapal, kerajinan kulit, tekstil, tambang tembaga dan bijih besi.

d. Dinasti Fathimiyah (919-1171 M)

Nama dinasti Fatimiyah disandarkan kepada tiang turusnya Fatimah binti Nabi Muhammad SAW, yang didirikan oleh kaum Syi'ah di Afrika Utara (Tunisia), kemudian meluas hingga Mesir dan Siria. Khilafah ini yang membangun kota Kairo (al-Qaahirah=perkasa) pada tahun $980 \mathrm{M}$ dengan ditandai dengan suatu monumen yang sangat masyhur, di dunia Islam khususnya, yaitu Universitas al-Azhar.

Dilihat dari pengembangan ilmu pengetahuan dan peradaban Islam, peran al-Azhar tidak diragukan lagi hingga saat ini dengan melahirkan ratusan ribu ulama' yang telah menyebarkan dakwah Islam di seluruh dunia. Di samping mendirikan al-Azhar, dinasti ini juga mengembangkan ilmu pengetahuan lewat penerbitan berbagai rujukan keilmuan. 
Di Kairo, yang menjadi ibukota kerajaan Fathimiyah, terdapat sebuah perpustakaan yang berisi sekitar satu juta enam ratus buku dari berbagai disiplin ilmu. Namun pada tahun $1171 \mathrm{M}$ dinasti Fathimiyah runtuh akibat dikalahkan oleh Shalahuddin al-Ayyubi, seorang raja Turki yang namanya sangat legendaris dalam perang Salib III.

Singkat kata, peradaban Islam pada masa-masa kejayaannya telah memenuhi dunia Islam dengan cahaya ilmu yang menyelubungi rumah-rumah, masjid-masjid, sekolah-sekolah, forum-forum, majelis-majelis, dan tokotoko sehingga benarlah apa yang dikatakan oleh Gustave Lebon. Katanya, Kecintaan bangsa Arab terhadap ilmu besar sekali. Mereka telah mencapai derajat kebudayaan yang tinggi setelah mereka menyelesaikan penaklukanpenaklukan dalam waktu yang sangat singkat. Karena itulah mereka mampu menciptakan sebuah peradaban yang membuat ilmu-ilmu, sastra-sastra dan seni-seni menjadi matang dan mencapai puncaknya. ${ }^{2}$

Kejayaan dunia Islam seperti di atas merupakan hal yang sangat kontras dengan dunia Barat, yang tengah tenggelam dalam melawan kegelapan zaman -masa itu lebih dikenal dengan sebutan the darkness ages-. Pada saat

\footnotetext{
${ }^{2}$ Musthafa As Siba'i, 2011, Peradaban Islam, versi digital,www.referensimuslim.com, 180
} 
para cendekiawan muslim sedang tekun mengkaji bermacam kitab ilmu pengetahuan di berbagai perpustakaan besar yang tersebar di seluruh wilayah Islam, pada waktu yang bersamaan keluarga raja Eropa tengah berusaha menuliskan nama-nama mereka dengan cara dieja.

\section{KEMUNDURAN DUNIA ISLAM}

Masa-masa kejayaan Islam yang telah berjalan beberapa abad lamanya, yang pengaruhnya telah merebak dan merambah jauh ke beberapa belahan dunia non muslim pada akhirnya juga mengalami masa-masa kemundurannya. Berbagai macam krisis yang sangat kompleks telah menerpa dunia Islam, di antaranya adalah:

1. Krisis dalam bidang sosial politik

Krisis ini bermula dari kerapuhan dalam penghayatan ajaran Islam, terutama yang terjadi di kalangan para penguasa. Ajaran Islam hanya sekedar diamalkan dari segi formalitasnya saja, bukan lagi dihayati dan diamalkan sampai pada hakikat dan ruhnya sebagaimana yang dicontohkan Rasulullah SAW. Akibatnya, para penguasa pemerintahan mulai dijangkiti penyakit rohani, seperti keserakahan terhadap kekuasaan dan kehidupan dunia yang sifatnya materi, iri dan dengki terhadap kehidupan 
orang lain yang lebih sukses. Sehingga mulailah muncul nafsu untuk saling berebut kekuasaan antar keluarga.

Keadaan pemerintahan Andalusia yang berada pada kondisi konflik intern ini dimanfaatkan oleh berbagai kerajaan Kristen di Spanyol, Seperti Navara, Castilia, dan Aragon untuk merebut kembali Spanyol dari kakuasaan Islam.

Demikian pula kekuasaan Abbasiyah di Baghdad yang diserbu oleh bangsa Turki pada tahun $1055 \mathrm{M}$, kemudian direbut oleh pasukan Mongol yang dipimpin oleh Hulagu Khan pada tahun 1258 M.

Akibat dari pertikaian dan perebutan kekuasaan itu, kota Andalusia dan Baghdad yang telah berabad-abad menjadi pusat pengembangan ilmu pengetahuan dan peradaban dunia berubah menjadi kota yang suram.

2. Krisis dalam bidang keagamaan

Krisis ini berpangkal dari lahirnya madzhabmadzhab dan aliran pemikiran dalam Islam. Aliran-aliran yang menonjolkan penggunaan akal seperti Mu'tazilah, Syiah, dan pemikiran para filosof Islam(Ibnu Sina, Ibn Rush dan lain-lain ) mulai dikalahkan oleh ajaran-ajaran yang mendasarkan pada "predeterminasi Tuhan"(takdir), serta pembakuan dasar-dasar hukum (fikih) Islam. Sehingga tidak banyak lagi kegiatan melakukan "ijtihad" (kreatifitas 
meninjau kembali qaidah-qaidah agama), dan kegiatan pengembangan ilmu pengetahuan.

Menjelang abad ke 14, para ulama "konservatif" berada dalam posisi dominan, berkat pengaruh Al-Ghazali yang unggul dalam polemiknya dengan para filosof seperti Ibn Rushd dan lain-lain. Para ulama tersebut mempunyai dua kekawatiran. Pertama, bahwa Alquran akan ditafsirkan seenaknya oleh para penulis yang tidak memenuhi syarat secara teologis. Yang kedua, tulisantulisan yang dihasilkan oleh para intelektual telah mulai mengambil alih otoritas dan kendali para ulama. Kelompok ulama "konservatif" kemudian mengadakan reaksi yang cukup keras. Mereka mengambil tindakan yang di kemudian hari sangat berpengaruh terhadap menurunnya dinamika masyarakat, yaitu: pertama, Mereka mempersempit konsep ilmu dari "yang meliputi semua jenis pengetahuan" menjadi hanya "ilmu pengetahuan agama".

Kedua, Mereka mengubah konsep ijma' dari 'konsensus masyarakat' menjadi 'konsensus orang berilmu', yang dimaksud orang berilmu adalah para ulama itu sendiri. Ketiga Mereka menutup pintu ijtihad: pemikiran bebas terhadap masalah agama menjadi tidak sah. 
Masyarakat berpegang pada taqlid (percaya secara membuta) terhadap agama dan hal-hal lainnya. Masyarakat Islam menjadi masyarakat yang tertutup. Para ulama 'konservatif' misalnya berusaha menghambat pengenalan mesin cetak ke negara-negara muslim selama tiga abad, dengan alasan pencetakan buku-buku oleh para penulis yang bukan ulama akan menimbulkan salah penafsiran terhadap ajaran agama.

3. Krisis dalam bidang pendidikan dan ilmu pengetahuan Krisis yang ketiga ini sesungguhnya hanya sekedar akibat dari krisis dalam politik sosial dan keagamaan. Dengan jatuhnya pusat kekuasaan Islam di Cordova dan Baghdad, maka pusat ilmu pengetahuan, baik yang berupa perpustakaan ataupun lembaga pendidikan turut punah tak berbekas. Sehingga berakibat pada makin menyempitnya ruang gerak para ilmuwan untuk mengembangkan keilmuan mereka. Cordova dan Baghdad yang semula menjadi lambang pusat peradaban dan ilmu pengetahuan beralih ke kota-kota besar Eropa.

\section{PERLUNYA PEMURNIAN DAN PEMBAHARUAN}

Masa kemunduran dunia Islam sebagaimana digambarkan sebelumnya, terus berlangsung sampai akhir abad ke-18. Pada awal abad ke-19, mulailah bermunculan usaha-usaha dari para 
ulama Islam yang berfikiran maju untuk membangun kemuliaan Islam dan kejayaan kaum muslimin. Gagasan seperti ini kemudian terkristal dalam suatu gerakan yang terkenal dengan Gerakan Pembaharuan atau Gerakan Reformasi yang lantang bersemboyan "Kembali kepada alQur'an dan al-Hadits".

Upaya pemurnian dan pembaharuan sangatlah penting jika kita menilik lagi fakta mengenai masa kejayaan Islam yang mengungguli seluruh bangsa di dunia pada saat itu. Kalau umat Islam menghendaki masa keemasan itu kembali lagi ke tangan mereka maka sudah sepatutnyalah untuk melihat faktor apa saja yang mendorong terwujudnya kegemilangan itu. Faktor-faktor tersebut dirangkum sebagai berikut: ${ }^{3}$

a. Berasas tauhid

Peradaban kita berpijak pada asas wahdaniah (ketunggalan) yang mutlak dalam aqidah. Peradaban kita adalah peradaban pertama yang menyerukan bahwa Tuhan itu satu dan tidak mempunyai sekutu dalam kekuasaan dan kerajaanNya. Hanya Dia yang disembah dan hanya Dia yang dituju oleh kalimat Hanya kepada-Mu kami menyembah dan hanya kepada-Mu kami memohon pertolongan (lyyaaka na`budu wa iyyaaka nas ta`iin). Hanya Dia yang memuliakan dan menghinakan, yang

${ }^{3}$ Mustafa as-Siba'I, op. cit., 24-31 
memberi dan mengaruniai. Tiada sesuatupun di langit dan di bumi kecuali berada kekuasaan dan pengaturan-Nya. Ketinggian dalam memahami wahdaniah ini mempunyai pengaruh besar dalam mengangkat martabat manusia, dalam membebaskan rakyat jelata dari kezaliman raja, pejabat, bangsawan dan tokoh agama.

Tidak itu saja, tapi wahdaniah ini juga berpengaruh besar dalam meluruskan hubungan antara penguasa dan rakyat, dalam mengarahkan pandangan hanya kepada Allah semata sebagai pencipta mahkluk dan Robb adalah Islam yang hampir membedakannya dari seluruh peradaban baik yang telah berlalu maupun yang akan datang, yakni kebebasannya dari setiap fenomena paganism (paham keberhalaan) dalam aqidah, hukum, seni, puisi dan sastra.

b. Kosmopolitanisme

Peradaban Islam bervisi kosmopolitan. Al-Qur`an telah menyatakan kesatuan jenis manusia meskipun berbeda-beda asal-usul keturunan, tempat tinggal dan tanah airnya. Hal ini sebagaimana dijelaskan dalam firman Allah Ta`ala:

‘Hai manusia, sesungguhnya Kami menciptakan kamu dari seorang laki-laki dan seorang perempuan dan menjadikan kamu berbangsa-bangsa dan bersuku-suku supaya kamu 
saling mengenal. Sesungguhnya orang yang paing mulia di antara kamu di sisi Allah ialah orang yang paling bertaqwa di antara kamu. Sesungguhnya Allah Maha Mengetahui lagi MahaMengenal.'(Al Hujurat 13)

Peradaban Islam tidak mengenal nation yang kecil dan terpecah-pecah. Sebaliknya, peradaban Islam menyatukan umat manusia dari beragam latar belakang ras, bangsa, wilayah geografis, keturunan dan beragam bahasa. Tanpa menghilangkan jati diri dan identitas masing-masing. Berasas pada moral yang agung, peradaban kita menjadikan tempat pertama bagi prinsipprinsip moral dalam setiap sistem dan berbagai bidang kegiatannya. Peradaban kita tidak pernah lepas dari prinsip-prinsip moral ini. Bahkan moral menjadi ciri khas peradaban Islam.

Islam tidak mengenal penjajahan dan eksploitasi kekayaan suatu negeri, apalagi menghina dan memperkosa wanita-wanita. Para penyebar Islam ke berbagai negeri justru menjadi guru dalam bidang moral buat setiap negeri yang dimasukinya. Peradaban Islam sungguh kontras peradaban Barat hari ini yang gencar mengekspor free sex, lesbianisme, homoseksual, hedonisme dan dekadensi moral. 
c. Menyatukan Agama dan Negara

Umumnya peradaban yang dikenal manusia memisahkan antara agama dengan negara. Seakan keduanya adalah dua sisi yang tidak bisa bertemu. Namun peradaban Islam mampu menciptakan tatanan negara dengan berpijak pada prinsip-prinsip kebenaran dan keadilan, bersandar pada agama dan aqidah tanpa menghambat kemajuan negara dan kesinambungan peradaban. Dalam peradaban Islam bahkan agama merupakan salah satu faktor terbesar kemajuan dalam bernegara. Maka, dari dinding masjid di Baghdad, Damaskus, Kairo, Cordoba, dan Granada memancarlah sinar-sinar ilmu ke segenap penjuru dunia.

d. Toleransi Yang Mulia

Peradaban kita mempunyai toleransi keagamaan yang mengagumkan, yang tidak pernah dikenal oleh peradaban lain yang juga berpijak kepada agama. Orang yang tidak percaya kepada semua agama atau Tuhan tidak tampak aneh jika ia memandang semua agama berdasarkan pengertian yang sama serta memperlakukan pemeluk-pemeluknya dengan ukuran yang sejajar. Cukuplah bagi kita untuk mengetahui bahwa peradaban kita menjadi unik dalam sejarah karena 
mendirikannya adalah berlandaskan satu agama tetapi keberadaannya untuk agama-agama lain seluruhnya.

Itulah beberapa karakteristik dan keistimewaan peradaban kita dalam sejarah peradaban. Semua karakteristik dan keistimewaan itu menjadikan peradaban kita sebagai objek kekaguman dunia dan menjadi pusat perhatian orang-orang merdeka dan cendekia dari setiap ras dan agama.

Maka menjadi kewajiban kita ketika melihat kemunduran Islam agar melakukan koreksi terhadap kesalahan-kesalahan yang menyebabkannya serta mencari cara untuk kembali bangkit menjadi umat yang utama.

\section{E. TOKOH PEMBAHARU DALAM DUNIA ISLAM}

a. Taqiyuddin Ibnu Taimiyyah

Ibnu Taimiyah dikenal sebagai seorang mujtahid dari Siria, yang lantang menyeru dan mengajak umat Islam di seluruh dunia untuk kembali berpegang teguh kepada ajaran alQur'an dan as-Sunnah yang murni dan penuh tanggung jawab dalam menata seluruh aspek kehidupan baik secara individu, keluarga, masyarakat maupun kehidupan bernegara. ${ }^{4}$ Bersamaan dengan itu ia juga mengajak umat Islam untuk

\footnotetext{
${ }^{4}$ Musthafa Kamal Pasha \& Ahmad Adaby Darban, Muhammadiyah Sebagai Gerakan Islam,(Yogyakarta: Pustaka SM, 2009), 31
} 
membuang jauh-jauh berbagai praktek penyimpangan nilai ajaran Islam yang mengarah pada perbuatan syirik, bid'ah, tahayul, taqlid, dan sebagainya.

Dialah seorang mujtahid yang pertama kali menyerukan bahwa pintu ijtihad tetap terbuka. Pernyataan semacam ini menghapus pemahaman di kalangan umat yang telah sekian lama meyakini bahwa pintu ijtihad sudah tertutup rapat. Keyakinan ini mengandung implikasi bahwa umat Islam tidak perlu lagi berijtihad, melainkan mencukupkan seluruh pemecahan masalah yang berkenaan dengan ajaran Islam kepada pendapat para imam madzhab yaitu Imam Malik, Imam Syafi'i, Imam Abu Hanifah, Imam Ahmad bin Hanbal.

b. Muhammad bin Abdul Wahab

Muhammad bin Abdul Wahab adalah pendiri gerakan Muwahidin. Ia dilahirkan di Najed, bagian timur dari Saudi Arabia. la dibesarkan dalam lingkungan kehidupan beragama yang ketat di bawah pengaruh madzhab Hanbali, yaitu suatu madzhab yang memperkenalkan dirinya sebagai aliran Salafiyah. Latar belakang aliran keagamaan Muhammad bin Abdul Wahab ternyata memiliki kesamaan dengan pendahulunya yaitu Ibnu Taimiyah yang juga dibesarkan dalam pengaruh madzhab Hanbali. Meskipun demikian, di 
kemudian hari keduanya akhirnya mampu melepaskan diri dari berbagai keterikatan formal dengan madzhab tersebut.

Gerakan Muhammad bin Abdul Wahab dalam melakukan ajaran Islam dilakukan dengan cara yang lugas, keras, dan tidak mengenal kompromi, terlebih jika menyangkut tauhid dan berbagai penyakit yang berhubungan dengannya seperti syirik, bid'ah, khurafat, dan tawashul. Model gerakannya yang seperti ini tak pelak menimbulkan rasa tidak senang dari pihak-pihak tertentu, khususnya para penguasa setempat, hingga pada puncaknya ia diusir dari negerinya sendiri. Di kemudian hari, para lawan perjuangannya menyebut gerakan Muhammad bin Abdul Wahab dengan Gerakan Wahabi.

Pokok ajaran Gerakan Wahabi adalah menyeru umat Islam untuk kembali kepada al-Qur'an dan as-Sunnah secara murni dan konsekuen, membuang segala bentuk kemusyrikan, serta menumbuhkan sikap berani berijtihad. Karena kesamaan pokok ajaran inilah, maka gerakan ini disebut sebagai mata rantai yang kedua dalam jajaran gerakan pembaharuan dalam Islam setelah gerakan kebangkitan Islam yang dipelopori oleh Ibnu Taimiyah. 


\section{c. Gerakan Salafiyah}

Gerakan Salafiyah lahir di Mesir pada abad ke-19, dan dipelopori oleh tiga pemikir Islam yaitu Jamaluddin alAfghany, Muhammad Abduh, dan Rasyid Ridha. Penamaan gerakan dengan nama gerakan Salafiyah karena pada hakekatnya gerakan ini meneruskan dan melestarikan gerakan yang dikobarkan oleh Ibnu Taimiyah beberapa abad sebelumnya.

Ibnu Taimiyah menamakan gerakan pemikiran yang didengungkannya dengan nama "Muhyi Atsaris Salaf", yaitu membangkitkan kembali ajaran orang terdahulu (Nabi SAW, sahabat, dan tabi'in). Kesamaan pemikiran ketiga tokoh ini dengan para pembaharu terdahulu adalah pada semangat untuk kembali kepada al-Qur'an dan as-Sunnah secara murni, membersihkan segala penyakit tauhid, dan mendorong semangat untuk berijtihad.

a) Jamaluddin al-Afghany

Dalam dunia Islam, Jamaluddin al-Afghany dikenal sebagai seorang mujaddid (reformer) sekaligus seorang mujahid (pejuang) yang terus menerus mengobarkan api semangat menegakkan "Kalimatulhaq" kepada siapapun, bahkan kepada penguasa yang zalim. la sangat menonjol sekali 
sebagai tokoh pejuang Islam dalam dunia politik, namun ia juga dikenal sebagai seorang pemikir dan filosof.

Dalam upayanya menyebarkan dan meluruskan ajaran Islam, Jamaluddin al-Afghany melakukan pengembaraan tidak hanya ke negeri-negeri Islam seperti India, Arab Saudi, Iran, Mesir, Turki, dan lainlain, namun juga sampai ke negeri-negeri non muslim di daratan Eropa seperti Inggris, Perancis, Jerman, serta Rusia.

Guna menyebarkan ide-ide pembaharuannya ke seluruh dunia Islam, ketika dia berada di Kota Paris, dia mengajak murid dan sahabat setianya, Muhammad Abduh, untuk menerbitkan majalah "alUrwatul Wutsqa". Majalah tersebut juga digunakan sebagai media pembinaan umat Islam dalam kesatuan ideologi, politik, serta strategi perjuangan mencapai cita-cita. Ide dan cita-cita untuk menggalang persatuan dan kesatuan umat Islam di seluruh dunia dengan semangat dan tali Islam inilah yang dinamakan Pan Islamisme. 
b) Muhammad Abduh

Muhammad Abduh dikenal sebagai sosok yang luar biasa karena kepandaiannya meliputi hampir seluruh bidang kehidupan. Dia tidak hanya dikenal sebagai seorang tokoh ahli tafsir, hukum Islam, bahasa Arab dan kesusasteraan, logika, ilmu kalam, filsafat, dan sosial, namun ia juga seorang ulama besar, penulis kenamaan, pendidik yang berhasil, pembaharu Mesir yang modern, pembela Islam yang gigih, wartawan yang tajam penanya, hakim dan politikus ulung, juga seorang mufti, suatu jabatan keagamaan tertinggi di Mesir.

Pada awal kiprahnya, dia mengikuti gurunya, Jamaluddin al-Afghany, yang bersama-sama menggunakan politik sebagai sarana dan strategi untuk mencapai cita-cita terwujudnya 'izzul Islam wal muslimin', yaitu kejayaan Islam dan kemuliaan umat Islam di belahan dunia manapun. Namun kemudian keduanya berbeda pandangan, sehingga Jamaluddin al-Afghany tetap menitikberatkan perjuangannya melalui jalur politik, yaitu dengan jalan revolusi. Sedangkan Muhammad Abduh menfokuskan perjuangannya pada bidang sosial pendidikan. Karena menurutnya revolusi dalam bidang politik tidak akan 
ada artinya sebelum ada perubahan mental sumber daya manusianya.

c) Rasyid Ridha

Rasyid Ridha dilahirkan di sebuah desa di Libanon. Dia adalah salah satu murid Muhammad Abduh yang paling disayangi dan paling dekat dengan gurunya. Pokok pemikirannya dalam pembaharuan Islam banyak memiliki kesamaan dengan pendahulunya, Jamaluddin al-Afghany dan Muhammad Abduh.

Pokok-pokok pikiran pembaharuan Rasyid Ridha antara lain sebagai berikut:

1. Pemahaman umat Islam tentang agamanya serta tingkah laku mereka banyak yang menyimpang dari ajaran Islam yang murni. Unutk itu umat Islam harus dibimbing kembali ke jalan Islam yang murni dan bersih dari segala bentuk bid'ah, khurafat, dan syirik

2. Agar segera terwujud kesatuan dan persatuan umat Islam maka dianjurkan untuk menjaga kerukunan atas dasar penuh toleransi dan tenggang rasa sekalipun berbeda madhzab

3. Kaum wanita harus diikutsertakan dalam berbagai kegiatan kemasyarakatan 
4. Sebagaian paham dan ajaran kaum sufi dianggapnya memperlemah ajaran Islam karena mereka melalaikan tugas dan kewajibannya di dunia. Mereka menanamkan paham yang pasif, pasrah kepada keadaan tanpa berusaha dan berikhtiar. Padahal yang benar adalah bahwa ajaran Islam adalah ajaran yang penuh dinamika dan optimisme, yang mendorong umatnya agar aktif mengolah bumi untuk mendapatkan kenikmatan Allah dan mensyukurinya.

Untuk mewujudkan segala paham dan cita-cita kesatuan dan persatuan umat Islam perlu mempunyai suatu Negara. Karena hanya dengan memiliki Negara seperti itu umat Islam akan dapat menerapkan undang-undang dan hukum Allah secara kongkret.

d. Gerakan Pembaharuan Islam di India dan Pakistan

India termasuk salah satu negeri yang memiliki kebudayaan kuno, sejajar dengan negeri Cina, Mesir, Babilonia, dan Yunani. la termasuk negeri di Asia yang di masa lampau sangat besar memberikan pengaruh peradaban dan kebudayaan yang bercirikan Hindu-Budha pada bangsa-bangsa Asia lainnya. Dan ketika Islam masuk pada abad ke-11 Masehi dan berkuasa selama 8 abad 
lebih, segala kebudayaan India yang telah tinggi ini semakin diperkaya dengan datangnya Islam yang selalu mendorong umatnya untuk menciptakan dan memajukan dunia dengan karya-karya kemanusiaan. Kemudian kekuasaan Islam mengalami kehancuran ketika Inggris menjarah dan menguasai negeri India. Tokoh Pembaharuan india yang dikenal sebagai pelopor, yaitu:

a) Syah Waliyullah

Di celah-celah masa suram kekuasaan Islam dari Dinasti Mughal, lahirlah seorang tokoh ulama dan pemikir besar bangsa India, Syah Waliyullah, yang sebagian orang menganggapnya lebih besar dari alGhazali dan Ibnu Rushd. Dia meninggalkan kesan yang abadi dalam perkembangan pemikiran Islam. Dan dari tokoh inilahuntuk pertama kalinya terpancar pikiranpikiran baru dalam usaha membangun kembali kejayaan Islam, baik dalam bidang politik, sosial, maupun intelektual.

Dalam ide pembaharuannya, dia menegaskan bahwa Islam adalah ajaran yang universal, yang selalu selaras dengan tuntutan segala zaman. 
b) Sir Sayed Ahmad Khan

Sir Sayed Ahmad Khan dikenal sebagai tokoh yang mengembangkan danmenyempurnakan ide-ide Syah Waliyullah. Dia memulai geraknya dengan mendirikan perkumpulan, menyebarkan kitab dan surat-surat edaran. Dan akhirnya pada tahun 1875 dia mendirikan sebuah lembaga pendidikan Mohammadan Anglo Oriental College (MAOC) di Aligarh. Seperti halnya tokoh pembaharu Islam lainnya, Ahmad Khan juga mencita-citakan bangunnya kembali kejayaan dan kemuliaan Islam di anak benua Asia.

Ahmad Khan mengajak umat Islam India untuk belajar menuntut ilmu di mana pun juga sampai pun mempelajari karya-karya dari Barat. Dia juga mengajak kaum muslimin untuk menekuni dan mendalami ilmu dialektika dan ilmu bahasa untuk menangkis berbagai paham hidup, terutama paham ketuhanan yang dihasilkan dari peradaban Barat. Upaya ini secara kongkrit diwujudkannya dengan membangun pusat pendidikan Islam di Aligarh. Dari sinilah digembleng kader-kader Islam India yang kelak meneruskan cita-cita perjuangan tokoh pembaharu Syah Waliyullah dan Ahmad Khan. 
Selain dua nama tokoh pembaharu di atas, ada lagi tokoh lain yang namanya tidak dapat ditinggalkan begitu saja dari deretan nama tokoh pembaharu di India, seperti:

a. Sayed Ameer Ali yang mengaku sebagai penganut paham Rasionalisme Islam dan memperjuangkan kebangkitan umat Islam melalui jalur pendidikan

b. DR. Muhammad lqbal yang menyatakan dirinya sebagai pendukung ide Pan Islamisme serta menyerukan kepada umat Islam agar kembali kepada etika agama dan politik model Islam Madinah, yaitu politik yang mengatur masyarakat dengan tatanan demokratis sebagaimana yang pernah terwujud pada jaman Rasulullah SAW.

c. Sayed Abul A'la Maududi, seorang tokoh yang memiliki ketajaman pikiran, lisan, dan tulisan, sehingga selama 60 tahun hidupnya dia telah menghasilkan 120 buku dengan topik yang sangat luas dalam berbagai bidang keilmuan. Bahkan buku-bukunya telah banyak yang disalin dalam berbagai bahasa dunia dan menjadi literatur di berbagai perguruan tinggi Islam di sekian banyak negeri Islam. 


\section{F. RANGKUMAN}

1. Kemajuan Peradaban Islam terjadi pada abad VII sampai X Masehi pada masa pemerintahan dinasti Umaiyah, Abbasiyah, dan Fathimiyah.

2. Jejak masa keemasan umat Islam dapat dilihat pada beberapa aspek yaitu perluasan wilayah kekuasaan Islam sampai Eropa, kemajuan bidang iptek, industri, ekonomi, serta lahirnya para ilmuwan Islam yang karyanya mendunia.

3. Kemunduran umat Islam disebabkan berbagai macam krisis yang sangat kompleks diantaranya krisis sosial politik, krisis keagamaan, krisis pendidikan dan iptek.Masa ini terus berlangsung sampai akhir abad ke-18.

4. Pada awal abad ke-19, mulai bermunculan usahausaha dari para ulama Islam untuk membangun kemuliaan Islam dan kejayaan kaum muslimin melalui Gerakan Pembaharuan atau Gerakan Reformasi dengan semboyan "Kembali kepada alQur'an dan al-Hadits".

5. Beberapa tokoh pembaharu yang muncul di beberapa Negara adalah Jamaluddin al-Afghany, Muhammad Abduh, Rasyid Ridha, Syah Waliyullah, Sir Sayed Ahmad Khan, 
G. LATIHAN SOAL

Jawablah soal-soal berikut ini:

1. Jelaskan mengenai sejarah terjadinya masa keemasan peradaban Islam.

2. Berikan contoh kemajuan peradaban Islam dalam bidang ilmu pengetahuan.

3. Jelaskan faktor-faktor yang menyebabkan kemunduran umat Islam

4. Sebutkan beberapa tokoh pembaharuan di dunia Islam beserta ide-ide pembaharuan yang mereka bawa

\section{H. REFERENSI}

As Siba'i, Musthafa. Peradaban Islam. versi digital. www.referensimuslim.com. 2011

Pasha, Musthafa Kamal \& Ahmad Adaby Darban. Muhammadiyah Sebagai Gerakan Islam. Yogyakarta: Pustaka SM. 2009

Yatim, Badri. Sejarah Peradaban Islam. Jakarta: PT. Raja Grafindo Persada, 2005

Hitti, Philip K.. History of the Arabs: From the Earliest Times to the Present. Terj. Cecep Lukman Yasin dan Dedi Slamet Riyadi. Jakarta: PT. Serambi Ilmu Semesta, 2005 


\section{BAB II}

\section{DAKWAH ISLAM NUSANTARA}

Mata Kuliah

: Al-Islam dan Kemuhammadiyahan 3

Capaian Pembelajaran

: Mahasiswa Mampu menganalisis teori

masuknya

Islam,

perkembangan, corak Islam di

Nusantara, serta hubungan kedatangan

Penjajah dan penyebaran Islam di Nusantara.

Alokasi Waktu

: $2 \times 50$ menit

Pertemuan ke

$: 3$

Kemampuan akhir yang diharapkan:

1. Menganalisis teori masuknya Islam di Nusantara

2. Menganalisis Proses perkembangan Islam Nusantara

3. Menganalisis Corak Islam Nusantara

4. Mengkorelasikan kedatangan Penjajah dengan penyebaran Islam Nusantara.

\section{PENDAHULUAN}

Dakwah Islam Islam Nusantara, pada bab ini menjelaskan tentang bagaimana teori masuknya Islam di Nusantara, proses masuknya Islam di Nusantara, sehingga memberikan corak pada perkembangannya serta hubungan kedatangan penjajah dengan penyebaran Islam di Nusantara. Dengan kajian ini diharapkan mahasiswa memiliki kemampuan sesuai indikator yang diharapkan. 


\section{A. TEORI MASUKNYA ISLAM DI NUSANTARA}

Secara garis besar teori masuknya Islam di Nusantara dibagi menjadi tiga, yakni:

1. Pendapat sarjana Orientalis Belanda, Snouck Hurgronje, "Islam datang ke Indonesia pada abad ke-13 M dari Gujarat (bukan dari Arab langsung) dengan bukti ditemukannya makam Sultan Malik as-Sholeh, raja pertama Kerajaan Samudra Pasai (berasal dari Gujarat).

2. Pendapat Sarjana Muslim, Prof HAMKA dan cendikiawan Muslim pada seminar Sejarah Masukknya Islam di Indonesia tahun 1963, Islam datang di Indonesia pada abad pertama Hijriah (abad ke 7- 8M) langsung dari Arab, dengan bukti jalur pelayaran yang bersifat internasional di selat Malaka yang menghubungkan Dinasti Tang di Cina (Asia Timur), Sriwijaya di Asia Tenggara dan Bani Umayyah di Asia Barat, sebelum abad $13 \mathrm{M}^{5}$

3. Pendapat Sarjana Muslim Kontemporer, Taufik Abdullah. la menggabungkan dua pendapat diatas, memang benar Islam sudah datang ke Indonesia sejak abad ke-7 atau $8 \mathrm{M}$, tetapi baru dianut oleh pedagang Timur Tengah di Pelabuhanpelabuhan. Barulah Islam masuk besar-besaran dan memiliki kekuatan politik pada abad $13 \mathrm{M}$ ditandai

${ }^{5}$ A.Hasymy, Sejarah Masuk dan Berkembangnya Islam di Indonesia, (Badung: Al-Maarif, 1981).hlm. 358 
berdirinya Kerajaan Samudra Pasai. Dengan didukung kehancuran Baghdad yang saat itu pusat kekuasaan Ismam Bani Abbasyiyyah.

Ketika para pedagang datang di Indonesia bersamaan itu datang pula da'i - da'i dan musafir - musafir sufi melalui jalur yang sama mereka melakukan interaksi tersebut terbentuklah pemukiman muslim. Pertumbuhan pemukiman muslim ini makin luas sehingga terbentuk tatanan ekonomi dan struktur pemerintahan di Gampung Samudra ${ }^{6}$ dengan menetapkan Meurah Silu sebagai kepala suku dengan gelar Sultan Malik as-Sholeh. ${ }^{7}$

\section{PERKEMBANGAN ISLAM DI NUSANTARA}

Islam di Indonesia merupakan salah satu cabang peradaban Islam di Asia Tenggara setelah hancurnya Peradaban Islam di Bagdad (1258 M). Tersebarnya Islam di Indonesia melalui jalur - jalur sebagai berikut: pertama, perdagangan, menggunakan sarana pelayaran. Kedua, Dakwah, yang dilakukan oleh pedagang, ada juga mubaligh dari para sufi. Ketiga, Perkawinan, perkawinan antara pedagang muslim dengan penduduk pribumi yang

${ }^{6}$ Nama salah satu provinsi di Aceh Utara

${ }^{7}$ Uka Tjandrasasmita, (E)., Sejarah Nasional III, (Jakarta:

Departemen Pendidikan dan Kebudayaan, 1979), hlm.86 
berasal dari putri raja, sehingga ulama memiliki keluasan untuk berdakwah dengan menggunakan kekuasaan. Keempat, Pendidikan. Ketika kedudukan pedagang mulai menguasai perekonomian, maka mereka mulai bergerak dibidang pendidikan, karena pusat perekonomian itu menjadi tempat pengembangan pendidikan dan dakwah Islam. Kelima, Tasawuf dan Tarekat. Bersamaan datangnya pedagang muslim datang pula para ulama, da'i dan sufi pengembara. 8 Yang selanjutnya para sufi diangkat menjadi penasehat raja atau pejabat agama kerajaan. Di Aceh ada Syaikh Hamzah Fansuri, Syamsuddin Sumatrani, Nuruddin ar Raniri, Abd. Rauf Singkel. Juga di Jawa yang dikenal dengan Wali Songo. ${ }^{9}$ Yang menyebarkan Islam melalui seni seperti: seni arsitektur, wayang, gamelan, musik, dan seni busana.

Melalui jalur - jalur tersebut Islam secara berangsur - angsur menyebar. Penyebaran Islam di Indonesia bisa dikategorikan dalam tiga tahap, yakni: Pertama, runtuhnya Kerajaan Majapahit pada abad ke-14 sampai ke-15. Masa ini penyebaran Islam masih sebatas di daerah pelabuhan. Kemudian masuk di pesisir dan pedesaan, pada saat ini pedagang, ulama-ulama guru

\footnotetext{
${ }^{8}$ Musyrifah Susanto, Sejarah Peradaban Islam Indonesia. (Jakarta. PT.Grafindo Persada, 2012), hlm.11

${ }^{9}$ Ibid, hlm.11
} 
tarekat (Wali di Jawa) serta murid-muridnya memiliki peranan penting. Penyebaran Islam masa ini diwarnai aspek tasawuf, hal ini terkorelasi dengan penafsiran mistik terhadap Islam dengan latar belakang kepercayaan masyarakat yakni Hindu, Budha dan sinkritisme kepercayaan lokal. Kedua, masa kekuasaan Kolonial Belanda sampai abad ke-19. Masa ini terjadi ketika VOC menguasai Nusantara khususnya wilayah dagang dan politik pada awal abad ke-18 di Jawa. Ketiga, berawal pada abad ke-20 terjadinya "liberalisasi" kebijakan pemerintah kolinial Belanda di Indonesia. Masa ini mulailah awal Islamisasi di Nusantara. ${ }^{10}$ Kondisi ini dampak dari defisit tinggi yang dialami akibat tiga perang besar (perang Paderi, Perang Diponegoro, dan Perang Aceh). Belanda memakai kebijakan cultuur stelses (tanam paksa) yang mengharuskan petani membayar pajak hasil pertanian yang dipaksakan, digagas oleh Gubernur Van den Bosch bertujuan untuk menambah kas pemerintah kolonial Belanda. Pada masa ini dibangun juga sarana non-fisik berupa sarana pendidikan untuk memenuhi kebutuhan perekonomian Belanda. Hal ini menimbulkan orientasi politik etis tahun 1901 dengan slogan kaum

${ }^{10}$ Azyumardi Azra, Renaisans Islam Asia Tenggara, Sejarah Wacana dan Kekuasaan, (Bandung: PT Remaja Rosda Karya, 1999), hlm. 8 
liberal: meningkatkan kemakmuran dan kemajuan rakyat tanah jajahan. ${ }^{11}$

Dalam perkembangannya, sistem pendidikan yang awalnya untuk memenuhi birokrasi kolonial akhirnya memunculkan elit baru intelektual modern akhirnya mengancam kekuasaan Kolonialisme sendiri. Dominasi politik dan ekonomi kolonial menghancurkan tatanan struktur tradisional, apalagi pajak yang dibebankan kepada rakyat dirasa memberatkan, sehingga rakyat lebih memilih pimpinan non formal dari sosok Kiai dan ulama. Kiai mau menjadi pemimpin gerakan melawan Belanda dan Birokrat tradisional disebabkan kekhawatirannya akan pengaruh budaya asing. Peran ulama dengan Pesantren - pesantrennya, pemukiman - pemukiman muslim, dan pengiriman murid-murid untuk belajar di Timur Tengah. Sepulangnya mereka memiliki pemikiranpemikiran baru, yang mendorong mereka mendirikan organisasi- organisasi di wilayah perkotaan.

Penyebaran Islam yang awalnya bersifat religio magis telah berubah menjadi organisasi - organisasi yang memiliki ideologi yang sudah terstruktur sebagai pengusung aspirasi keislaman, sehingga di Nusantara

${ }^{11}$ Taufik Abdullah, (Ed), Sejarah Umat Islam Indonesia, (Majelis Ulama Indonesia, 1991), hlm.39. 
Islam merupakan peletak dasar bagi nasionalisme Indonesia.

\section{B. CORAK ISLAM NUSANTARA}

Islam di Nusantara memiliki kekhasan yang dengan mudah dapat dikenali oleh masyarakat umum, mulai dari keragaman organisasi dan kelompok - kelompok yang mengatas namakan agama Islam. Dari sisi ideologi Islam di Indonesia lebih dikenal dengan Islam Tradisionalis. Hal ini didukung bukti sejarah bahwa penyebaran Islam yang dilakukan pedagang dan ulama tidak menolak sosial kultural masyarakat sekitar bahkan mereka melakukan integrasi budaya dan ajaran agama dalam proses penyebarannya.

Islam yang datang di Indonesia bercorak Islam Tasawuf, yakni pemahaman agama yang lebih condong pada olah rohani daripada masalah duniawi. Hubungan antara Nusantara dan Timur Tengah (sebagai pusat Islam) merupakan hubungan yang berkesinambungandari generasi kegenerasi. Awalnya bermula dari hubungan perdagangan, kemudian jaringan ulama, selanjutnya jaaringan tasawuf/tarekat, akhirnya berpengaruh pada perubahan yang terjadi di timur Tengah juga berpengaruh pada Islam di Indonesia. 
Islam di Indonesia menurut Ibn Batutah masih berorientasi pada Mazhab Syafi'i yang bercorak ortodok. Di Malaku dalam tulisan orang Belanda Jacob Van Neik (1596) menggambarkan penduduk di Banda (Maluku), merupakan orang-orang yang melaksanakan shalat dengan khusu', lengkap dengan Masjid, azan, dan do'a - do'a yang sesuai dengan Syari'at. ${ }^{12}$ Begitu pula di Jawa, dibuktikan dengan adanya naskah Islam Jawa kuno pada abad ke-16, yakni Primbon Jawa dari Banyu Mas dan Wejangan Seh Bari, keduanya menyebutkan peguron Karang di bawah bimbingan seorang guru bernama She Bari yang menyebarkan ajaran para Wali Jawa. Wali sendiri di Jawa lebih dikenal ulama yang tidak hanya mengajarkan kelslaman tetapi juga mengajarkan ilmu kesaktian dan kekebalan. Ilmu ini diajarakan oleh Sunan Kalijaga dan Sunan Kudus. ${ }^{13}$ Dari naskah Wejangan Seh Bari yang dikenal dengan Kitab Sunan Bonang, rujukannya hanya dari Kitab Al-Ghazali, yakni Ihya Ulumuddin dan Kitab Tamhid fi Bayan al-Tauhid karya Abu Syukkur al-Kasyi al-Salimi. Catatan tersebut menunjukkan penekanan ajaran Islam pada akidah dan Tasawuf.

${ }^{12}$ Musyarifah Sunanto, Op.Cit., hlm.226

${ }^{13}$ Martin Van Bruinessen, Kitab Kuning, Pesantren dan Tarekat, Bandung: Mizan, 1995. Hlm. 26 


\section{HUBUNGAN KEDATANGAN PENJAJAH DENGAN PENYEBARAN ISLAM DI NUSANTARA}

Kehidupan umat Islam di Indonesia dalam melaksanakan keagamaan dan dakwahnya selama kurang lebih tiga abad (sekitar awal abad ke-16) berlangsung secara damai, tiba - tiba datang bangsa - bangsa Eropa menjajah diawali dari Bangsa Spanyol, Portugis, Inggris dan Belanda. Semua Bangsa - bangsa tersebut menjajah dengan motif pertama, ekonomi (Gold), dengan motif ini penjajah melakukan berbagai cara untuk memiskinkan negara jajahannya. Kedua, politik (Glory). Motif ini dilakukan oleh bangsa penjajah untuk pembodohan negara jajahannya agar mereka tetap buta huruf sehingga mudah dikuasi dan dibohongi. Ketiga, agama (Gospel). Motif ini merupakan misi yang utama bagi mereka, dalam prakteiknya bangsa penjajah melakukan pemurtadan/Kristenisasi misi inilah sebenarnya yang lebih utama. Karena mereka menganggap ini adalah tugas suci (mission sacre), menyelamatkan domba-domba yang hilang.

Brain Horison dalam buku Muhammadiyah sebagai Gerakan Islam yang ditulis Musthafa Kamal Pasha dan Ahmad Adaby menjelaskan, orang - orang Spanyol dan Portugis sengaja datang ke pelosok dunia untuk memerangi Islam dan menggantikannya dengan Kristen. Begitu pula ketika bangsa 
Portugis masuk ke Asia Tenggara yang di dalamnya ada Indonesia, mereka memaksa penduduk pribumi untuk memeluk agama Kristen dan melaksanakan Pembaptisan besar-besaran serta menghapuskan monopoli Islam dalam perdagangan rempah - rempah setelah penakhlukan Konstatinopel oleh Turki (Ottoman 1453) orang Barat tidak mendapatkan kesempatan tersebut, sehingga bangsa Portugis berhasil mendirikan pos-pos perdagangan yang dipersenjatai di India dan China, sambil melanjutkan peperangan di perairan Asia. ${ }^{14}$

Bukti - bukti sejarah bahwa Belanda datang ke Indonesia adalah dalam rangka misi tugas suci adalah, pada abad 19 orang Belanda yang berada di negerinya sendiri maupun di hindia Belanda menghilangkan pengaruh besar penyebaran Islam di Indonesia dengan program Kristenisasi secara cepat. Pada saat pemerintahan Hindia Belanda dipimpin oleh Gubernur Jendral A.W.F. Indenburg (19091916) memiliki program Kritening Politiek dan dibantu dengan dana-dana dari negara.

Menghadapi kehadiran bangsa penjajah yang membawa misi Glory membuat komunitas Muslim terusik khususnya di wilayah pesantren. Komunitas ini merasa

${ }^{14}$ Mustthafa Kamal Pasha, Ahmad Adaby Darban.

Muhammadiyah Sebagai Gerakan Islam. Yogyakarta: Citra Karsa Mandiri, 2005. Hlm.72. 
terancam terhadap eksistensinya sebagai komunitas Islam yang diincar untuk dimurtadkan oleh penjajah, maka pndok pesantren mulai mengubah "kurikulumnya" kalau semula pendidikan pesantren diarahkan untuk membentuk santri yang benar-benar memahami, menghayati dan mengamalkan ajaran Islam sesuai dengan al-Qur'an dan As-sunnah, sehingga terbentuk manusia yang mukhsin dan muslih mulai sejak itu ditanamkan sikap benci terhadap kaum kafir penjajah. Pesantren secara intensif menanamkan sikap fanatisme terhadap Islam juga membentuk jiwa nasionalisme dan patriotisme dengan menggunakan idiom-idiom Islam, seperti: haram bekerja sama dengan Belanda, haram bekerja di kantor Belanda, haram berpakaian meniru Belanda (kafir), dan sebagainya. Akhirnya pada masa ini muncullah gelombang ortodoksi di pesantren dengan memunculkan pusat sentimen terhadap Belanda. Sebab setiap aspirasi muslim diejek dan difitnah oleh Barat, di negrinya sikap nasionalis dan patriotisme di Timur disebut fanatisme, Barat memiliki harga diri, kehormatan dan kemuliaan Bangsa di Timur dikatakan "Chauvinisme". Di Barat nilai sentimen ke Bangsaan di Timur dikatakan sebagai "Penyakit benci kepada orang asing".

Inilah awal pergerakkan Islam di Nusantara ini dalam kegiatan politik yang mencita-citakan kemerdekaan dan 
menyebarkan benih-benih persatuan Indonesia, dan kelompok ini pula yang pertama kali memerang penjajah. Diantaranya: Perang Paderi (1821-1837), Perang Aceh (18731904) perang Diponegoro (1825-1830) tercatat sebagai perang termahal dan paling banyak menelan korban. Ketiga perang ini mengusung bendera Islam dalam perjuangannya.

\section{RANGKUMAN}

1. Secara garis besar teori masuknya Islam di Nusantara dibagi menjadi tiga, pertama: Islam datang ke Indonesia pada abad ke-13 M dari Gujarat (bukan dari Arab langsung). Kedua: Islam datang di Indonesia pada abad pertama Hijriah (abad ke 7- 8M) langsung dari Arab. Ketiga: menggabungkan dua pendapat diatas, memang benar Islam sudah datang ke Indonesia sejak abad ke-7 atau $8 \mathrm{M}$, tetapi baru dianut oleh pedagang Timur Tengah di Pelabuhan-pelabuhan. Barulah Islam masuk besar-besaran dan memiliki kekuatan politik pada abad $13 \mathrm{M}$.

2. Penyebaran Islam di Indonesia bisa dikategorikan dalam tiga tahap, yakni: Pertama, runtuhnya Kerajaan Majapahit pada abad ke-14 sampai ke-15. Kedua, masa kekuasaan Kolonial Belanda sampai abad ke-19. Ketiga, 
berawal pada abad ke-20 terjadinya "liberalisasi" kebijakan pemerintah kolinial Belanda di Indonesia.

3. Islam yang datang di Indonesia bercorak Islam Tasawuf, yakni pemahaman agama yang lebih condong pada olah rohani daripada masalah duniawi.

4. Bangsa penjajah datang dengan motif: pertama, ekonomi (Gold), dengan motif ini penjajah melakukan berbagai cara untuk memiskinkan negara jajahannya. Kedua, politik (Glory). Motif ini dilakukan oleh bangsa penjajah untuk pembodohan negara jajahannya agar mereka tetap buta huruf sehingga mudah dikuasi dan dibohongi. Ketiga, agama (Gospel). Motif ini merupakan misi yang utama bagi mereka, dalam prakteiknya bangsa penjajah melakukan pemurtadan/Kristenisasi misi inilah sebenarnya yang lebih utama. Karena mereka menganggap ini adalah tugas suci (mission sacre).

\section{E. LATIHAN}

1. Sebutkan teori - teori masuknya Islam di Indonesia!

2. Jelaskan faktor - faktor yang mempengaruhi penyebaran Islam di Nusantara!

3. Jelaskan corak Islam yang berkembang di Nusantara!

4. Apakah hubungan pesantren dengan penyebaran Islam di Nusantara? 
5. Jelaskan pengertian Gold, Glory dan Gospel yang diusung penjajah di negara jajahan!

6. Mengapa Islam masa penjajahan terlihat sangat rendah dan terpojokkan? Jelaskan!

\section{F. DAFTAR PUSTAKA}

Mustthafa Kamal Pasha, Ahmad Adaby Darban. Muhammadiyah Sebagai Gerakan Islam. Yogyakarta: Citra Karsa Mandiri, 2005.

Azyumardi Azra, Renaisans Islam Asia Tenggara, Sejarah Wacana dan Kekuasaan, (Bandung: PT Remaja Rosda Karya, 1999).

Taufik Abdullah, (Ed), Sejarah Umat Islam Indonesia, (Majelis Ulama Indonesia, 1991).

A.Hasymy, Sejarah Masuk dan Berkembangnya Islam di Indonesia, (Badung: Al-Maarif, 1981). 
BAB III

\section{SEJARAH MUHAMMADIYAH}

Nama Mata Kuliah

Semester

SKS

Pertemuan ke-

Lama Jam pertemuan
: AIK 3 (KE-MUHAMMADIYAH-AN)

: III

: 2 sks

$: 3$

$: 2 \times 50$ menit

Kemampuan akhir yang diharapkan:

1. Memahami faktor obyektif dan subyektif didirikannya Muhammadiyah

2. Memahami profil K.H. Ahmad Dahlan

3. Memahami pemikiran K.H. Ahmad Dahlan tentang Islam dan Umatnya

A. PENDAHULUAN

Pada bab ini akan dijelaskan sejarah berdirinya Muhammadiyah secara Obyektif maupun subyektif. memahami profil KH. Ahmad Dahlan serta memahami Pemikiran KH. Ahmad Dahlan tentang Islam dan Umatnya.

B. FAKTOR OBYEKTIF DAN SUBYEKTIF DIDIRIKANNYA MUHAMMADIYAH 
Secara lebih konsepsional berdirinya Muhammadiyah dilatar belakangi oleh dua faktor, yaitu faktor subyektif dan faktor obyektif. Yang dimaksud dengan faktor subyektif adalah faktor dari subyek pendirinya, yaitu KH. Ahmad Dahlan sendiri. la adalah orang yang sangat tekun mempelajari ilmu agama dengan mendalami isi yang terkandung dalam al-Quran dan alHadits. Ahmad Dahlan percaya bahwa dalam al-Quran dan alHadits terdapat nilai-nilai yang dapat dijadikan sebagai landasan untuk mengubah situasi dan kondisi umat Islam yang mengalami keterbelakangan. Setiap hari ia berusaha keras untuk menemukan nilai-nilai fundamental yang ada dalam Al al-Quran dan al-Hadits untuk kemudian diterapkan dalam kehidupan riil. la selalu melakukan tadabbur atau memperhatikan dan mencermati dengan penuh ketelitian terhadap apa yang tersirat dalam Al-Quran. Dari sini kemudian Ahmad Dahlan menemukan beberapa ayat - di antaranya adalah Surat Ali Imran ayat $104^{15}$ dan Surat al-Ma'un - yang memberinya spirit untuk melakukan perubahan terhadap situasi dan kondisi masyarakat, bangsa dan agama yang terjadi pada saat itu. Setelah pulang dari Makkah, ia

${ }^{15}$ Artinya: dan hendaklah ada di antara kamu sekalian segolongan umat yang menyeru kepada kebajikan, menyuruh yang ma'ruf dan mencegah yang mungkar, merekalah orang-orang yang beruntung 
kemudian mendirikan organisasi yang bernama Muhammadiyah untuk melakukan perubahan. ${ }^{16}$

Selain faktor subyektif, berdirinya Muhammadiyah juga dilatarbelakangi oleh faktor obyektif. Yang dimaksud dengan faktor obyektif adalah situasi kondisi dan kenyataan yang berkembang pada masa itu. Apa yang ada dalam pikiran dan hati sanubari Ahmad Dahlan disulut oleh situasi dan kondisi yang berkembang pada masyarakat saat itu. Ada beberapa hal yang menjadi penyebab obyektif didirikannya Muhammadiyah sebagai lembaga sosial keagamaan. Faktor obyektif dibagi menjadi dua, yaitu faktor obyektif internal umat Islam dan eksternal umat Islam.

Di antara faktor internal umat Islam adalah:

1. Di kalangan umat Islam Indonesia, terdapat berbagai amalan yang tidak murni dan tidak ada tuntunannya dalam al-Quran dan al-Hadits. Ketidakmurnian amalan umat Islam Indonesia disebabkan karena al-Quran dan al-Hadits tidak dijadikan sebagai satu-satunya rujukan dalam beragama Islam. $^{17}$

Sebelum datangnya Islam, masyarakat Indonesia sudah mengenal berbagai macam agama dan kepercayaan seperti Hindu,

\footnotetext{
${ }^{16}$ Slamet Abdullah dan M. Muslich KS, Seabad Muhammadiyah dalam Pergumulan Budaya Nusantara, Yogyakarta: Global Pustaka Utama, 2010, hal. 49

${ }^{17}$ Ibid., hal. 50
} 
Budha dan kejawen. Kedatangan Islam ke Indonesia juga telah bercampur dengan berbagai macam kebudayaan maupun tradisi lokal Indonesia sebagai konsekuensi dari agama yang datang paling akhir. Akibatnya banyak sekali ritual keagamaan yang tidak ada tuntunannya dalam syariat, yang oleh kaum puritan dikategorisasikan sebagai bid'ah, khurafat, takhayul bahkan syirik.

2. Lembaga pendidikan milik umat Islam belum mampu menyiapkan generasi yang siap mengemban misi selaku "Khalifah Allah diatas bumi". ${ }^{18}$

Sebagai tokoh pembaharu, Ahmad Dahlan sangat gelisah melihat sistem pendidikan yang dijalankan oleh pesantrenpesantren tradisional di Indonesia yang hanya mengutamakan hafalan. Banyak sekali pondok pesantren di Indonesia yang hanya menggunakan sistem pendidikan klasik dalam mendidik para santrinya sehingga para santri tidak mempunyai daya kritis, kurang peka terhadap realitas sosial serta tidak mampu mengantisipasi perubahan zaman yang sangat dinamis. Sebagai salah satu lembaga pendidikan, pesantren memang telah mengabdi kepada masyarakat, tetapi sistem yang dipakai kadang terlalu monolitik sehingga tidak mampu mengantisipasi perubahan zaman dan dinamika peradaban manusia.

${ }^{18}$ Ibid., hal. 60 
Ahmad Dahlan merasa bahwa pesantren pada masanya belum mampu memproduksi mujtahid handal, karena hanya mempelajari ilmu-ilmu agama yang bersifat ukhrawiyah oriented seperti ilmu fiqhuddin yang meliputi ilmu bahasa arab, tafsir, hadis, tasawuf, akhlak, akidah, ilmu mantiq dan ilmu falak, sedangkan ilmu yang terkait dengan ilmu-ilmu keduniawian yang sering disebut dengan ilmu pengetahuan umum jarang atau bahkan mungkin tidak pernah diajarkan oleh pesantren tradisional. Padahal menurut pemahaman Ahmad Dahlan, hanya dengan menguasai ilmu-ilmu pengetahuan umum, maka manusia akan mampu mengemban misinya sebagai Khalifatullah fi al-ardli.

Selain faktor obyektif internal, berdirinya Muhammadiyah juga dilatarbelakangi oleh faktor obyektif eksternal di antaranya:

1. Semakin meningkatnya gerakan Kristenisasi di tengah-tengah masyarakat Indonesia. ${ }^{19}$

Setiap penjajah yang datang ke negara-negara jajahannya pasti mempunyai misi tertentu dan salah satunya adalah mempengaruhi budaya, agama, serta gaya hidup masyarakat. Begitu juga dengan Belanda yang menjajah Indonesia, juga mempunyai tujuan untuk mengibarkan tiga G, yaitu Glory, Gold dan Gospel. Ketiga motif ini seakan telah menjadi bagian dari bangsa penjajah untuk menaklukan negara-negara jajahannya. Glory adalah motif dari penjajahan untuk menjadi pemenang atau

${ }^{19}$ Ibid., hal. 64 
menjadi penguasa di negara-negara jajahannya. Belanda datang ke Indonesia salah satu tujuannya adalah untuk menguasai daerah jajahannya agar daerah jajahan menjadi budak. Setiap langkah yang diambil oleh penduduk pribumi yang bertujuan merdeka pasti mendapat ancaman dari bangsa penjajah.

Motif yang kedua adalah untuk mendapatkan emas atau kekayaan. Tidak ada bangsa penjajah yang tidak mempunyai tujuan untuk mengeruk kekayaan alam negara jajahannya, termasuk Belanda yang mengusung sumber daya alam Indonesia ke negeri kincir angin tersebut. Akibatnya tuan rumah tidak dapat menikmati tanahnya sendiri karena mau tidak mau harus diserahkan kepada Belanda. Selama kurang lebih 350 tahun Belanda menjajah bumi pertiwi yang kaya sumber daya alam ini sehingga banyak kekayaan sumber daya alam kita dimakan oleh rakyat Belanda.

Sebagai negara yang dijajah maka Indonesia semakin lama bukan semakin maju tetapi semakin miskin. Kemiskinan, ketidakadilan serta penderitaan yang diderita oleh masyarakat Indonesia inilah yang kemudian menggerakkan orang-orang seperti Ahmad Dahlan untuk membentuk lembaga pendidikan yang dapat meningkatkan kualitas sumber daya manusia Indonesia sehingga mereka mempunyai kepekaan sosial yang tinggi terhadap kondisi masyarakat bangsa dan negara. 
Motif yang ketiga adalah gospel yaitu motif untuk menyebarkan ajaran agama kristen kepada rakyat Indonesia atau dalam bahasa yang lebih ekstrem ingin mengubah agama anak negeri jajahan menjadi Kristen. Sebagai tuan di negara orang lain tentunya mereka mempunyai kekuatan untuk mengambil hati budak dinegeri ini secara ekonomi sangat lemah. Ketika perut dalam kondisi lapar maka tidak ada pilihan lain untuk mempertahankan hidup kecuali menjual kepercayaan. Oleh karena itu dalam bahasa agama, "Islam tidak menyukai kemiskinan karena kemiskinan dapat mendekatkan seseorang kepada kekufuran". Penduduk pribumi yang sudah tertindas semakin sengsara karena harus menjual kepercayaan untuk menyelamatkan jiwa mereka.

2. Penetrasi Bangsa Eropa, terutama Bangsa Belanda ke Indonesia.

Kedatangan bangsa Belanda ke Indonesia membawa dampak buruk terhadap kebudayaan Indonesia serta mengancam eksistensi nilai-nilai moral Islam karena bangsa Barat mengajarkan sekularisme. Parahnya lagi, model pendidikan Barat mengajarkan kepada masyarakat sifat intelektualistik, individualistik, elitis serta diskriminatif. Karakter ini jelas bertentangan dengan budaya bangsa Indonesia yang masih menonjolkan kebersamaan dan bersendikan etika moral keagamaan. Kedatangan bangsa Belanda 
juga berpengaruh terhadap pemikiran masyarakat dari yang bercorak spiritualisme menjadi rasionalisme dan menonjolkan individualisme. Kenyataan ini membuat geram umat Islam terutama lembaga/organisasi keislaman karena mereka mempunyai tanggung jawab moral untuk membentengi moralitas masyarakat Indonesia.

Berdirinya lembaga pendidikan Muhammadiyah selain bertujuan untuk mencerahkan kehidupan bangsa juga sebagai wahana untuk menghambat penetrasi budaya Barat yang sudah sangat menggurita. Dengan memiliki lembaga pendidikan sendiri, maka Muhammadiyah dapat mendidik murid-muridnya untuk mempelajari syariat secara independen.

\section{PROFIL K.H. AHMAD DAHLAN}

Berdirinya Muhammadiyah tidak terlepas dari jasa besar Kyai Haji Ahmad Dahlan sebagai tokoh sentral. Berkat pemikiran, ijtihad serta kemauan kerasnya, maka Muhammadiyah dapat berdiri tegak serta mampu mengabdikan dirinya pada umat Islam Indonesia pada khususnya dan seluruh rakyat Indonesia pada umumnya.

Ahmad Dahlan dilahirkan di kampung Kauman, Daerah Istimewa Yogyakarta pada tahun $1868 \mathrm{M}$ dengan nama kecil Muhammad Darwis. Ia terlahir dari pasangan suami istri Siti Aminah dan KH. Abu Bakar. Ayahnya adalah seorang khatib Masjid 
Besar Kesultanan Yogyakarta, yang jika dilacak silsilahnya sampai kepada Maulana Malik Ibrahim. Sedangkan ibunya adalah putri dari $\mathrm{KH}$. Ibrahim seorang penghulu dari Kesultanan Yogyakarta. Dengan demikian maka dalam diri Muhammad Darwis mengalir darah ulama yang sangat kental karena bapak ibunya berasal dari keturunan ulama. ${ }^{20}$

Ketika menginjak usia sekolah, Muhammad Darwis tidak disekolahkan di Sekolah gubernemen, karena ada anggapan di masyarakat bahwa barang siapa yang memasuki sekolahan tersebut dianggap kafir atau Kristen. Oleh karenanya, ia diajari ilmu agama oleh bapaknya sendiri di rumah dengan dasar-dasar ilmu agama dan mengaji Al-Quran. Muhammad Darwis kecil termasuk anak yang cerdas, karena pada umur delapan tahun, ia sudah lancar membaca Al-Quran bahkan telah mengkhatamkannya dengan fasih. Setelah fasih membaca AlQuran maka ia belajar ilmu fiqih kepada KH. Muhammad Shaleh dan belajar nahwu KH. Muhsin. Keduanya adalah kakak ipar dari Muhammad Darwis sendiri. Setelah ia menguasai ilmu pokok ajaran Islam kemudian ia belajar dengan KH. Muhammad Nur dan KH. Abdul Hamid dalam berbagai ilmu agama. Jadi, Muhammad Darwis kecil adalah orang yang tidak mengenyam pendidikan formal, karena pendidikan pada waktu itu adalah barang mahal

\footnotetext{
${ }^{20}$ Musthafa Kamal Pasha \& Ahmad Adaby Darban, Muhammadiyah Sebagai Gerakan Islam,(Yogyakarta: Pustaka SM, 2009), 91
} 
yang tidak bisa dijangkau oleh semua orang. Kenyataannya ketidakbisaan sekolah formal ini membakar semangat $\mathrm{KH}$. Ahmad Dahlan untuk mendirikan sekolah sendiri agar semua orang -tidak melihat status sosial, ekonomi, maupun agama- dapat sekolah karena pendidikan adalah hak semua orang. Lembaga pendidikan yang didirikan ini juga menjadi embrio berdirinya organisasi Muhammadiyah.

Setelah menginjak usia dewasa Muhammad Darwis dinikahkan dengan Siti Walidah, putri dari Muhammad Fadil, kepala penghulu Kesultanan Yogyakarta pada tahun 1889. Jadi, Siti Walidah tersebut masih saudara sepupu Muhammad Darwis. Setelah menikah, Muhammad Darwis, atas saran ibundanya kemudian menunaikan ibadah haji. la sampai di Makkah pada bulan Rajab tahun $1308 \mathrm{H}$ atau tahun 1890 M. Selain menunaikan ibadah haji, kepergian Muhammad Darwis ke Makkah juga mempunyai misi untuk memperdalam ilmu agama, karena Makkah pada waktu itu adalah sumber pengetahuan Islam. Setelah selesai menunaikan haji dan umrah, ia kemudian bersilaturahim, dengan beberapa ulama, baik ulama Indonesia maupun Arab seperti yang telah dipesankan oleh ayahnya. Kehausannya dalam mencari ilmu pengetahuan, mengantarkan Muhammad Darwis ke gerbang para alim seperti KH. Mahfud Termas, KH. Nahrowi Banyumas dan KH. Muhammad Nawawi Banten. Selain belajar ilmu agama dengan ulama Indonesia, 
Darwis juga belajar dengan ulama Arab Saudi di Masjidil Haram, bahkan sempat mendatangi ulama madzhab Syafi'i Bakri Syata'. Selain menuntut ilmu Darwis juga mendapat ijazah nama Ahmad Dahlan untuk menggantikan nama kecilnya.

Setelah memperdalam ilmunya, Muhammad Darwis kemudian pulang ke Yogyakarta pada minggu pertama bulan Shafar $1309 \mathrm{H}$ atau tahun 1891 M. Bekal ilmu yang ia dapatkan dari Makkah kemudian ditularkan pada para santri ayahnya, terutama santri remaja. Karena kecerdasan serta penguasaan ilmu agamanya yang tinggi, maka oleh ayahnya kemudian ia serahi mengajar para santri, baik remaja maupun dewasa. Bahkan setelah kematian ayahnya pada tahun 1896, KH. Ahmad Dahlan kemudian menggantikan jabatan ayahnya sebagai khatib Masjid Kauman dengan nama khatib Amin.

Jabatannya sebagai khatib ini memunculkan ketegangan antara Ahmad Dahlan dengan kaum tradisionalis dikarenakan beberapa pandangan Ahmad Dahlan yang berseberangan dengan mereka. Untuk menghilangkan ketegangan antara kaum tradisionalis dengan Ahmad Dahlan tersebut, maka pihak kesultanan kemudian meminta agar Ahmad Dahlan disingkirkan. Alhasil, Ahmad Dahlan kemudian dibiayai oleh pemerintah kesultanan untuk berangkat ke Makkah selama dua tahun untuk menetralisir keadaan. Di balik berkecamuknya keadaan Ahmad Dahlan kemudian menunaikan ibadah haji yang kedua serta 
menetap selama dua tahun di jazirah Arab tersebut. Pengasingan tersebut digunakan oleh Ahmad Dahlan untuk lebih memperdalam ilmu agamanya di Arab Saudi. Selain menunaikan ibadah haji, Ahmad Dahlan mempergunakan pengasingannya di Makkah untuk memperdalam ilmu pengetahuan agamanya dengan belajar pada beberapa Syeikh yang dianggap mumpuni dalam keilmuannya.

Setelah mempunyai bekal ilmu agama yang memadai, maka Ahmad Dahlan kemudian memutuskan pulang Yogyakarta untuk menyebarkan ajaran Islam yang benar sesuai dengan keyakinannya. Setelah sampai di tanah air, Ahmad Dahlan kemudian sibuk untuk mengajarkan ilmu agama yang telah ia peroleh dari Makkah pada para santrinya. Agar dakwah Islamiyahnya lebih fokus maka ia kemudian mendirikan pondok pesantren untuk menampung murid-muridnya yang berasal dari luar kota Yogyakarta. Di pondok pesantren sederhana inilah Ahmad Dahlan menggembleng santrinya dengan pengajianpengajian ilmu falak, tafsir dan tauhid yang asli dari Arab. Berbagai macam kitab yang diajarkan adalah kitab-kitab karya pembaharu Islam seperti karya Muhammad Abduh, Ibnu Taimiyah, Rasyid Ridla, Rahmatullah al hindi, Atha'illah, majalah al urwatul wutsqa dan kitab-kitab hadis madzhab Hambali.

Berbagai macam kitab tersebut dikaji secara kritis agar nilainilainya dapat diambil untuk mengangkat harkat dan martabat 
umat Islam Indonesia yang baru mengalami penjajahan dan penindasan. Metode pembelajaran yang menggunakan logika serta memungkinkan adanya tanya jawab inilah yang kemudian menarik simpati para santrinya sehingga semakin lama santri Ahmad Dahlan semakin banyak. Pondok pesantren inilah yang nantinya menginspirasi Ahmad Dahlan untuk mendirikan sekolah Islam yang kemudian menjadi embrio berdirinya Muhammadiyah.

\section{PEMIKIRAN K.H. AHMAD DAHLAN TENTANG ISLAM DAN UMATNYA}

\section{Pemikiran Pendidikan}

Pendidikan adalah sebuah kegiatan yang menekankan pada aspek proses sehingga persoalan-persoalan pendidikan termasuk persoalan ijtihadiyyah yang banyak membuka peluang bagi umat Islam untuk dapat mencermati dan mengkritisi prosesnya. Ajaran Islam hanya memberi garis pokoknya, sedangkan detailnya diserahkan kepada akal sehat.

Untuk itulah, K.H. Ahmad Dahlan merasa perlu memberikan sumbangsih pemikirannya terhadap kemajuan pendidikan Islam sekembalinya ia dari Mekkah. Ia memulainya dengan dakwah menyebarkan ajaran Islam melalui khutbah, terutama ketika ia dipercaya sebagai khatib tetap di Masjid Agung. Usahanya untuk memperbaiki sistem pendidikan Islam 
mulai menampakkan hasilnya ketika ia, atas dorongan Budi Utomo, mendirikan sekolah di Yogyakarta pada tahun 1911. Sekolah yang didirikannya menggunakan sistem modern, di mana ia memadukan pelajaran agama dan pelajaran umum, serta menggunakan kelas yang terdapat meja dan papan tulis sebagai sarana belajar seperti di sekolah Belanda pada saat itu.

Usaha K.H. Ahmad Dahlan mendirikan sekolah yang demikian adalah sebagai jawaban atas keprihatinannya terhadap kualitas umat Islam. Banyak umat Islam yang tenggelam dalam kebodohan, keterbelakangan, dan kejumudan. Kondisi ini diperparah dengan adanya tekanan politik kolonial Belanda yang sangat merugikan bangsa Indonesia. System pendidikan Islam yang digagas Ahmad Dahlan meskipun pada awalnya banyak ditentang oleh tokohtokoh masyarakat, di kemudian hari nyatanya banyak didirikan sekolah Islam dengan model demikian.

\section{E. PEMIKIRAN KEAGAMAAN}

Selain menggagas sistem pendidikan modern, K.H. Ahmad Dahlan juga berupaya memperbaiki kualitas umat Islam pada sisi yang lain. Misalnya, ide pemikirannya mengenai pembenahan arah kiblat. Berdasarkan Ilmu Hisab yang ia pelajari, arah kiblat umat Islam Indonesia tidaklah lurus ke barat sebagaimana yang telah diterapkan di masjid-masjid 
Jawa, melainkan miring $241 / 2$ derajat ke arah utara. Pemikiranini dikemukakannya kepada para ulama dari Yogyakarta dan sekitarnya melalui dialog terbuka, namun usahanya tidak menuai dukungan. Hingga akhirnya iabersama murid-muridnya meluruskan arah kiblat dengan memberi garis putih pada lantai Masjid Besar sesuai arah yang ia yakini kebenarannya. Usaha ini berbuah pemecatannya sebagai Khatib di Masjid Agung Yogyakarta. Namun KH Ahmad Dahlan tidak berputus asa. la lalu mendirikan langgar dengan kiblat mengarah ke barat laut, namun langgar ini kemudian juga dirobohkan oleh masyarakat.

Selain masalah keterbelakangan pendidikan yang menjadi titik awal pemikiran $\mathrm{KH}$ Ahmad Dahlan untuk mendirikan Muhammadiyah, masalah aqidah juga menjadi masalah utama yang menimbulkan keresahan pada diri beliau. Praktek keberagamaan masyarakat banyak diwarnai unsur takhayul, bid'ah, dan khurafat karena dipengaruhi oleh agama dan kepercayaan hindu budha sebagai agama yang dianut masyarakat sebelum Islam datang. Oleh karena itu, KH Ahmad Dahlan memprioritaskan upaya pembaharuan dan pemurnian ajaran Islam dari ritual-ritual yang berbau syirik dan merusak kemurnian tauhid. 
2. Pemikiran Sosial Kemasyarakatan

Pemikiran Ahmad Dahlan dalam hal ini didasari oleh pemahamannya terhadap surat al-Ma'un. Menurutnya, seseorang tidak hanya cukup menjadi pribadi yang baik bagi dirinya, melainkan ia juga harus baik untuk masyarakat sekitarnya. Ahmad Dahlan bahkan dikenal sebagai man of action, yaitu manusia amal, ${ }^{21}$ yang menekankan pada pentingnya amaliah dalam menjalani kewajiban sebagai Hamba dan Khalifatullah. Bagi Ahmad Dahlan, melayani kaum miskin, anak yatim, dan kaum dhu'afa lainnya merupakan panggilan keagamaan sebagai wujud dari konsistensi menjalani agama, sebaliknya menelantarkan dan tidak peduli dengan kaum lemah itu merupakan bentuk dari pendustaan terhadap agama Islam.

Hal ini dibuktikannya dengan mendirikan dan menyediakan layanansosial dan kesehatan yang dilembagakan melalui Penolong Kesengsaraan Oemoem (PKO). Melalui Al-Ma'un dan PKO, Muhammadiyah menghadirkan Islam sebagai gerakan pembebasan pemberdayaan masyarakat.Buah pemikiran dan tindak nyatanya tersebut menjadikan Muhammadiyah sebagai

\footnotetext{
${ }^{21}$ Haedar Nashir, Muhammadiyah Abad Kedua, (Yogyakarta: Suara Muhammadiyah, 2011), 74
} 
organisasi yang menonjol dalam gerakan pelayanan sosial dan kesehatan, bahkan boleh disebut sebagai pelopor.

F. RANGKUMAN

1. Faktor-faktor yang mendorong didirikannya Muhammadiyah adalah :

Faktor subyektif yaitu keinginan Ahmad Dahlan untuk mengimplementasikan al-Qur'an dan as-Sunnah untuk mengubah kondisi masyarakat. Faktor obyektif diantaranya:

- Ketidakmurnian praktek ajaran Islam

- Dualisme sistem pendidikan antarasistem pendidikan barat dan sistem pendidikan pesantren

- Kolonialisme

- Kristenisasi

2. Ahmad Dahlan lahir di Kauman Yogyakarta pada tahun 1869 dan wafat 1923 dalam usia muda, 54 tahun. Dua kali bermukim di Mekkah dan pulang menjadi mujaddid melawan pikiran-pikiran yang jumud. Karya pembaruan terbesarnya adalah Muhammadiyah yang dia dirikan pada 8 Dzulhijjah 1330 H bertepatan 18 November 1912 M. 
3. Pemikiran-pemikiran Ahmad Dahlan yang menjadi landasan bagi berdirinya Muhammadiyah adalah

- Sistem pendidikan modern yang menggabungkan antara pelajaran agama dan pelajaran umum

- Perbaikan praktek beragama yang mencakup pembenahan arah kiblat, pemurnian aqidah, dan

- Kepedulian sosial

\section{G. LATIHAN SOAL}

1. Jelaskan faktor subyektif dan obyektif didirikannya Muhammadiyah

2. Hal-hal apa saja yang mempengaruhi pemikiran Ahmad Dahlan

3. Jelaskan pemikiran Ahmad Dahlan yang dijadikan landasan bagi berdirinya Muhammadiya

H. REFERENSI

Abdullah, Slamet dan M. Muslich KS. Seabad Muhammadiyah dalam Pergumulan Budaya Nusantara. Yogyakarta: Global Pustaka Utama. 2010

Nashir, Haedar. Muhammadiyah Abad Kedua. Yogyakarta: Suara Muhammadiyah. 2011 
Pasha, Musthafa Kamal \& Ahmad Adaby Darban.

Muhammadiyah Sebagai Gerakan Islam. Yogyakarta:

Pustaka SM. 2009 


\section{BAB IV}

\section{KEPRIBADIAN MUHAMMADIYAH}

Nama Mata Kuliah

Semester

SKS

Pertemuan ke-

Lama Jam pertemuan
: AIK 3 (KE-MUHAMMADIYAH-AN)

: III

: 2 sks

$: 4$

$: 2 \times 50$ menit

Kemampuan akhir yang diharapkan :

1. Memahami hakikat Muhammadiyah

2. Memahami dasar amal usaha Muhammadiyah

3. Memahami pedoman amal usaha dan perjuangan Muhammadiyah

4. Memahami sifat Muhammadiyah

\section{A. PENDAHULUAN}

Pada bab ini akan dibahas tentang memahami hakikat, dasasr amal usaha, pedoman amal usaha dan perjuangan serta sifat Muhammadiyah.

B. KEPRIBADIAN MUHAMMADIYAH

Kepribadian Muhammadiyah adalah rumusan yang menggambarkan hakekat Muhammadiyah, serta apa yang menjadi dasar dan pedoman amal usaha dan perjuangan Muhammadiyah, serta sifat-sifat yang dimilikinya. Kepribadian 
Muhammadiyah ini berfungsi sebagai landasan, pedoman, dan pegangan bagi gerak Muhammadiyah menuju cita-cita terwujudnya masyarakat utama, adil makmur yang diridhai Allah Subhaanahu wa Ta'ala. ${ }^{22}$

Latar belakang dirumuskannya Kepribadian Muhammadiyah didasarkan pada beberapa masalah, yaitu:

1. Adanya kekaburan terhadap pemahaman Agama Islam di kalangan Muhammadiyah, termasuk di kalangan para aktifis Muhammadiyah, khususnya para penerus perjuangan Muhammadiyah, lebih-lebih di kalangan pengelola amal usaha.

2. Memudarnya semangat perjuangan terjadinya penyimpangan gerak langkah Muhammdiyah disebabkan ketidakjelasan arah, tujuan terhadap cita-cita perjuangan Muhammadiyah di kalangan anggota khususnya pada generasi penerus Muhammadiyah.

3. Adanya ketidakfahaman akan kepribadian Muhammadiyah pada para penerus perjuangan Muhammadiyah, menyebabkan mereka terombangambing oleh gerakan-gerakan dan paham agama yang berkembang dalam masyarakat.

${ }^{22}$ Hamdan Hambali, Ideologi dan Strategi Muhammadiyah,(Yogyakarta: Suara Muhammadiyah, 2011), 39 
4. Masuknya pengaruh luar yang tidak sesuai denganruh,cita-cita semangat perjuangan Muhammadiyah yang menyebabkan kelesuan / melemahnya dedikasi, hilangnya loyalitas terhadap citacita perjuangan Muhammadiyah, sikap mental yang materialistik, penyimpangan arah perjuangan Muhammadiyah.

\section{SEJARAH PERUMUSAN KEPRIBADIAN MUHAMMADIYAH}

Kepribadian Muhammadiyah dirumuskan pada saat Muhammadiyah dipimpin oleh Kolonel H.M. Yunus Anis pada periode 1959-1962. Idenya berasal dari uraian K.H. Faqih Usman mengenai "Apa sih Muhammadiyah itu?" pada saat memberikan pelatihan yang diadakan oleh Pimpinan Pusat Muhammadiyah di Madrasah Mu'allimin Muhammadiyah Yogyakarta. ${ }^{23}$

Rumusan Kepribadian Muhammadiyah itu kemudian disempurnakan dan disahkan pada Muktamar Muhammadiyah ke-35 pada tahun 1962 di Jakarta yang juga dikenal dengan Muktamar Setengah Abad.

Sesungguhnya, Kepribadian Muhammadiyah itu merupakan ungkapan dari kepribadian yang memang sudah ada pada Muhammadiyah sejak lama berdiri. K.H. Faqih Usman pada saat

${ }^{23}$ Haedar Nashir, Memahami Ideologi Muhammadiyah, (Yogyakarta: Suara Muhammadiyah, 2016), 130 
itu hanyalah memunculkan dan menegaskan kembali apa yang sudah ada sebagai nilai-nilai yang dipegang Muhammadiyah ke dalam sebuah rumusan tertulis, jadi bukan merupakan hal baru dalam Muhammadiyah. Adapun mereka yang menganggap Kepribadian Muhammadiyah sebagai hal baru, hanyalah karena mereka mendapati Muhammadiyah sudah tidak dalam keadaan yang sebenarnya. ${ }^{24}$

\section{MATAN (TEKS) KEPRIBADIAN MUHAMMADIYAH ${ }^{25}$}

1. Hakikat Muhammadiyah

Muhammadiyah adalah persyarikatan yang merupakan gerakan Islam. Maksud geraknya ialah dakwah Islam amar ma'ruf nahi munkar yang ditujukan pada dua bidang; perseorangan dan masyarakat. Dakwah dan amar ma'ruf nahi munkar pada bidang yang pertama terbagi menjadi dua golongan:

a. Kepada yang Islam, bersifat pembaharuan (tajdid) yaitu mengembalikan kepada ajaran-ajaran Islam yang murni.

b. Kepada yang belum Islam, bersifat seruan dan ajakan untuk memeluk agama Islam.

Adapun dakwah dan amar ma'ruf nahi munkar yang kedua, ialah kepada masyarakat, bersifat perbaikan dan bimbingan

${ }^{24}$ Haedar Nashir (peng.), Manhaj Gerakan Muhammadiyah Ideologi, Khittah, dan Langkah, (Yogyakarta: Suara Muhammadiyah, 2013), 46-47

${ }^{25}$ Haedar Nashir, Memahami Ideologi Muhammadiyah, 132-134 
serta peringatan. Kesemuanya itu dilaksanakan bersama dengan bermusyawarah atas dasar takwa dan mengharap keridhaan Allah semata-mata.

Dengan melaksanakan dakwah dan amar ma'ruf nahi munkar dengan caranya masing-masing yang sesuai, Muhammadiyah menggerakkan masyarakat menuju tujuannya, yaitu terwujudnya masyarakat Islam yang sebenar-benarnya.

2. Dasar Amal Usaha Muhammadiyah

Dalam perjuangan melaksanakan usaha menuju tujuan terwujudnya masyarakat Islam yang sebenar-benarnya di mana kesejahteraan, kebaikan, dan kebahagiaan luas merata, Muhammadiyah mendasarkan segala gerak dan amal usahanya atas prinsip-prinsip yang tersimpul dalam Muqaddimah Anggaran Dasar, yaitu:

a. Hidup manusia harus berdasarkan tauhid, ibadah, dan taat kepada Allah

b. Hidup manusia bermasyarakat

c. Mematuhi ajaran-ajaran agama Islam dengan keyakinan bahwa ajaran Islam itu satu-satunya landasan kepribadian dan ketertiban bersama untuk kebahagiaan dunia dan akhirat

d. Menegakkan dan menjunjung tinggi agama islam dalam masyarakat adalah kewajiban sebagai ibadah kepada Allah dan ihsan kepada manusia 
e. Ittiba' kepada langkah dan perjuangan Nabi Muhammad SAW

f. Melancarkan amal usaha dan perjuangan dengan ketertiban organisasi

3. Pedoman Amal Usaha Dan Perjuangan Muhammadiyah

Menilik dasar prinsip tersebut di atas maka apapun yang diusahakan dan bagaimanapun cara perjuangan Muhammadiyah untuk mencapai tujuan tunggalnya harus berpedoman "Berpegang teguh akan ajaran Allah dan rasulNya, bergerak membangun di segala bidangdan lapangan dengan menggunakan cara serta menempuh jalan yang diridhai Allah"

4. Sifat Muhammadiyah

Memperhatikan uraian tentang a. Apakah Muhammadiyah itu? b. Dasar dan amal usaha Muhammadiyah, dan c. Pedoman amal usaha dan perjuangan Muhammadiyah, maka Muhammadiyah memiliki dan wajib memelihara sifat-sifatnya, terutama yang tersebut di bawah ini:

a. Beramal dan berjuang untuk perdamaian dan kesejahteraan.

b. Memperbanyak kawan dan mengamalkan ukhuwah Islamiyah. 
c. Lapang dada, luas pandangan dengan memegang teguh ajaran Islam.

d. Bersifat keagamaan dan kemasyarakatan.

e. Mengindahkan segala hukum, undang-undang, peraturan serta Dasar dan Falsafah Negara yang sah.

f. Amar ma'ruf nahi mungkar dalam segala lapangan serta menjadi contoh tauladan yang baik.

g. Aktif dalam perkembangan masyarakat dengan maksud islah dan pembangunan sesuai dengan ajaran islam.

h. Bekerja sama dengan golongan Islam manapun juga dalam usaha menyiarkan dan mengamalkan agama Islam serta membela kepentingannya.

i. Membantu pemerintah serta bekerja sama dengan golongan lain dalam memelihara dan membangun Negara untuk mencapai masyarakat adil dan makmur yang diridhai Allah.

j. Bersifat adil serta korektif kedalam dan keluar dengan bijaksana.

I. RANGKUMAN

1. Kepribadian Muhammadiyah adalah rumusan yang menggambarkan hakekat Muhammadiyah, serta apa yang menjadi dasar dan pedoman amal usaha dan perjuangan Muhammadiyah, serta sifat-sifat yang dimilikinya. 
2. Kepribadian Muhammadiyah berfungsi sebagai landasan, pedoman, dan pegangan bagi gerak Muhammadiyah menuju cita-cita terwujudnya masyarakat utama, adil makmur yang diridhai Allah Subhaanahu wa Ta'ala.

3. Muhammadiyah adalah persyarikatan yang merupakan gerakan Islam amar ma'ruf nahi munkar yang ditujukan pada perseorangan dan masyarakat

4. Muhammadiyah mendasarkan segala gerak dan amal usahanya atas prinsip-prinsip yang tersimpul dalam Muqaddimah Anggaran Dasar

5. Perjuangan Muhammadiyah untuk mencapai tujuan tunggalnya harus berpedoman "Berpegang teguh akan ajaran Allah dan rasulNya, bergerak membangun di segala bidang dan lapangan dengan menggunakan cara serta menempuh jalan yang diridhai Allah"

\section{J. LATIHAN SOAL}

1. Apakah Kepribadian itu?

2. Jelaskan latar belakang disahkannya Kepribadian Muhammadiyah

3. Apakah fungsi Kepribadian Muhammadiyah?

4. Apakah hakekat Muhammadiyah itu?

5. Jelaskan prinsip-prinsip yang dijadikan landasan Muhammadiyah dalam gerak dakwah dan amal usahanya 
K. REFERENSI

Hambali, Hamdan. Ideologi dan Strategi

Muhammadiyah. Yogyakarta: Suara Muhammadiyah. 2011

Nashir, Haedar (peng.). Manhaj Gerakan

Muhammadiyah Ideologi Khittah, dan Langkah. Yogyakarta:

Suara Muhammadiyah. 2013

Nashir,Haedar.Memahami Ideologi Muhammadiyah.

Yogyakarta: Suara Muhammadiyah. 2016 


\section{BAB V}

MATAN KEYAKINAN DAN CITA-CITA HIDUP MUHAMMADIYAH

Matakuliah : Al-Islam dan Kemuhammadiyahan 3

Capaian Pembelajaran : Mahasiswa Mampu menganalisis teori

masuknya Islam, perkembangan, corak

Islam di Nusantara, serta hubungan kedatangan Penjajah dan penyebaran Islam di Nusantara.

Alokasi Waktu $\quad: 2 \times 50$ menit

Pertemuan ke $\quad: 5$

Indikator

2.1 Menelaah Sejarah Perumusan MKCH

2.2 Identifikasi Identitas dan Asas Muhammadiyah

2.3 Menjelaskan Keanggotaan Muhammadiyah

2.4 Menjelaskan keorganisasian Muhammadiyah

2.5 Memetakan pemikiran dan gerakan Muhammadiyah dalam bidang Aqidah, Ibadah, Akhlak dan Mu'amalah

\section{A. PENDAHULUAN}

Dalam bab ini akan dijelaskan tentang Matan Keyakinan dan Cita-cita Hidup Muhammadiyah, yang meliputi; sejarah perumusannya, identitas dan asas Muhammadiyah, keanggotaan, keorganisasian serta Pemikiran dan Gerakan 
Muhammadiyah dalam bidang Aqidah, Ibadah, akhlak dan mu'amalah.

\section{B. Sejarah Perumusan}

Matan Keyakinan dan Cita-cita Hidup Muhammadiyah yang lebih dikenal dengan istilah $\mathrm{MKCH}$, merupakan hasil dari putusan Sidang Tanwir Muhammadiyah tahun 1969 di Ponorogo Jawa Timur, sebagai bentuk pelaksanaan keputusan Muktamar Muhammadiyah ke-37 Tahun 1968 di Yogyakarta.

Hasil Sidang Tanwir Ponorogo terdiri 9 ayat, kemudian disempurnakan pada tahun 1970 dalam Sidang Tanwir Muhammadiyah di Yogyakarta menjadi 5 ayat yang menjadi tema Tajdid (Pembaharuan) dalam 5 bidang:

1. Ideologi

2. Khittah Perjuangan

3. Gerak dan Amal Usaha

4. Organisasi

5. Sasaran

Beberapa nama tokoh Muhammadiyah tercatat sebagai penggagas dalam perumusan $\mathrm{MKCH}$, yaitu:

1. Buya KH. Malik Ahmad

2. Buya AR. Sutan Mansur

3. Prof.Dr.H.M.Rasyidi

4. KH. M. Djindar Tamimy 
5. KH. Djarnawi Hadikusuma

6. KH. AR Fachruddin

7. Drs. Mohammad Djazman al-Kindi ${ }^{26}$

Berikut ini, Matan "Keyakinan dan Cita-cita Hidup Muhammadiyah" Keputusan Tanwir tahun 1969 di Ponorogo, yaitu:

1. Muhammadiyah adalah gerakan berasas Islam, bercita-cita dan bekerja untuk terwujudnya masyarakat Islam yang sebenar-benarnya, untuk melaksanakan fungsi dan missi manusia sebagai hamba dan khalifah Allah di muka bumi.

2. Muhammadiyah berkeyakinan bahwa Islam adalah Agama Allah yang diwahyukan kepada rasul-Nya, sejak Nabi Adam as, Ibrahim as, Isa as, dan seterusnya sampai kepada Nabi Muhammad saw., sebagai hidayah dan rahmat Allah kepada umat manusia sepanjang masa dan menjamin kesejahteraan hidup matriil dan spirituil, duniawi dan ukhrawi.

3. Muhammadiyah dalam mengamalkan Islam berdasarkan:

a. Al-Qur'an : Kitab Allahyang diwahyukan kepada Nabi Muhammad saw.

${ }^{26}$ Tim AIK UMM, 2005. Al-Islam dan Kemuhammadiyahan 3 (Kemuhammadiyahan). Malang, UMM Press. Hlm.80 
b. Sunnah Rasul : Penjelasan dan Pelaksanaan ajaran - ajaran Al-Qur'an yang diberikan oleh Nabi Muhammad saw. Dengan menggunakan akal pikiran sesuai dengan jiwa ajaran Islam.

4. Muhammadiyah bekerja untuk terlaksananya ajaran ajaran Islam yang meliputi bidang - bidang:
a. Aqidah
b. Akhlak
c. Ibadah
d. Muamalah Duniawiyah

4.1. Muhammadiyah bekerja untuk tegaknya aqidah Islam yang murni, bersih dari gejalagejala kemusyrikan, bid'ah dan khurafat, tanpa mengabaikan prinsip toleransi menurut ajaran Islam.

4.2. Muhammadiyah bekerja untuk tegakkan nilainilai akhlak mulia dengan berpedoman kepada ajaran-ajaran Al-Qur'an dan AsSunnah, tidak bersendi pada nilai - nilai ciptaan manusia.

4.3. Muhammadiyah bekerja untuk tegaknya ibadah yang dituntunkan oleh Rasulullah saw tanpa tambahan dan perubahan dari manusia. 
4.4. Muhammadiyah bekerja untuk tegaknya muamalat duniawiyat (pengolahan dunia dan pembinaan masyarakat) dengan berdasarkan ajaran agama serta menjadikan semua kegiatan dalam bidang ini sebagai ibadah kepada Allah SWT.

5. Muhammadiyah mengajak segenap lapisan bangsa Indonesia yang telah mendapat karunia Allah berupa tanah air yang mempunyai sumber - sumber kekayaan, kemerdekaan bangsa dan negara Republik Indonesia yang bersifat Pancasila, untuk berusaha bersama-sama menjadikan suatu negara yang adil, makmur dan diridlai Allah SWT. Baldatun thayyibatun wa rabun ghafur. ${ }^{27}$

Dari uraian Matan Keyakinan dan Cita-cita Hidup Muhammadiyah tersebut dapat disederhanakan sebagai berikut, untuk memudahkan warga Muhammadiyah memahaminya. Lima ayat tersebut dibagi menjadi tiga kelompok, yakni:

Kelompok kesatu : Mengandung pokok - pokok persoalan yang bersifat idologis (ada di

nomor 1 dan 2).

${ }^{27}$ Musthafa Kamal Pasha dan Ahmad Adaby. Muhammadiyah Sebagai Gerakan Islam. 2005. Yogyakarta, Citra Karsa Mandiri. hlm265 
Kelompok kedua : mengandung pokok-pokok persoalan mengenai faham agama

menurut Muhammadiyah (ada di

nomor 3 dan 4).

Kelompok ketiga : Mengandung persoalan mengenai fungsi dan missi Muhammadiyah dalam masyarakat negara Republik Indonesia (ada dinomor 5).

\section{IDENTITAS DAN ASAS MUHAMMADIYAH}

Identitas (hakekat) Muhammadiyah merupakan gerakan Islam, Dakwah Amar Ma'ruf Nahi Mungkar dan Tajdid, bersumber pada Al-Qur'an dan As-sunnah. ${ }^{28}$ Sedangkan Asas Muhammadiyah adalah Islam. Tujuannya adalah menegakkan dan menjunjung tinggi agama Islam sehingga terwujudnya masyarakat Islam yang sebenar-benarnya. ${ }^{29}$ Untuk mewujudkan maksud dan tujuan Muhammadiyah tersebut maka, dibentuklah program - program kerja dan kegiatan yang menghasilkan amal usaha - amal usaha sebagai bentuk mewujudkan masyarakat Islam yang sebenar-benarnya. Qur'an Surat Ali-Imran:104 merupakan salah satu identitas Muhammadiyah. Kata "waltakum minkum ummatun"

${ }^{28}$ Anggaran Dasar Muhammadiyah Bab II, Pasal 4.hlm.9

${ }^{29}$ Ibid,hlm.9 
merupakan penafsiran dari pentingnya gerakan Islam melalui organisasi atau persyarikatan.

Disamping itu Muhammadiyah juga dikenal dengan gerakan tajdid dakwah tajdid Muhammadiyah tercermin sebagai pelopor pendiri sekolah Islam modern, pelayanan kesehatan dan kesejahteraan (mendirikan majelis PKU, kepanjangan dari Penolong Kesengsaraan Oemoem yang sekarang menjadi Pembina Kesejahteraan Ummat), penyantunan anak yatim dan miskin melalui gerakan alMa'un, dan mendobrak pemikiran Islam yang jumud (statis). Maka tidak elak Muhammadiyah di masyarakat dikenal sebagai gerkan reformis dan modernis.

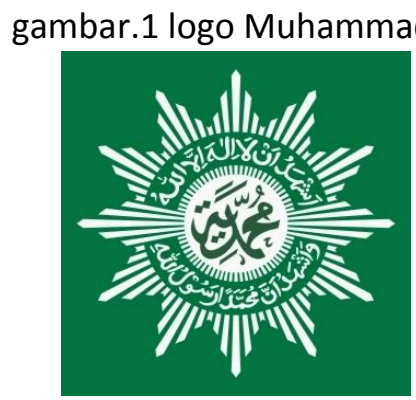

http://logogambar.blogspot.co.id/2015

Arti lambang Muhammadiyah, Matahari merupakan pusat tata surya sekaligus sumber dari kehidupan di muka bumi, sehingga Muhammadiyah diharapkan sebagai sumber kekuatan spiritual dan nilai-nilai Islam yang bertumpu pada 
dua kalimat syahadat. 12 Sinar Matahari memancar, merupakan wujud gerakan Muhammadiyah dalam memperjuangkan ajaran Islam sesuai tahun didirakannya (1912). Warna putih pada lambang Muhammadiyah memiliki arti kesucian dan keihlasan. Warna hijau sebagai warna dasar lambang Muhammadiyah memiliki arti kedamaian dan kesejahteraan. (hppt: http://logogambar.blogspot.co.id)

Muhammadiyah merupakan persyarikatan yang menampakan Islam otentik dan berkemajuan. Maka pahamilah Muhammadiyah dengan pengetahuan yang luas seperti halnya KH.Ahmad Dahlan Mendirikan Muhammadiyah, jangan sebagian-sebagian.

\section{E. Keanggotaan Muhammadiyah.}

Keanggotaan Muhammadiyah diatur dalam Anggaran Dasar (AD) Muhammadiyah Bab IV pasal 8 ayat 1: anggota Muhammadiyah terdiri atas, anggota biasa, anggota luar biasa, dan anggota kehormatan.

1. Anggota biasa adalah warga negara Indonesia beragama Islam.

2. Anggota Luar Biasa ialah orang Islam bukan warga negara Indonesia.

3. Anggota Kehormatan ialah perorangan beragama Islam yang bersaja terhadap Muhammadiyah dan 
atau karena kewibawaan dan keahliannya bersedia membentu Muhammadiyah. ${ }^{30}$

\section{F. KEORGANISASIAN MUHAMMADIYAH}

Struktur persyarikatan Muhammadiyah diatur dalam AD Muhammadiyah Bab V pasal 9, yakni: Ranting, Cabang, Daerah, Wilayah dan Pusat.

1. Ranting adalah suatu kesatuan anggota pada kawasan dimana anggotanya pengajian anggota secara berkala sekurang-kurangnya satu bulan sekali. Memiliki Mushallah atau surau sebagai pusat kegiatan dan yang terpenting ada jama'ah.

Pengesahan pendirian Ranting ditetapkan oleh Pimpinan Daerah atas usul anggota setelah mendapat persetujuan dari Cabang. (ART pasal 5)

2. Cabang adalah kesatuan Ranting disuatu tempat, yang terdiri sekurang-kurangnya tiga ranting. Cabang memiliki fungsi sebagai:

a. Pembinaan, pemberdayaan, dan koordinasi ranting.

b. Penyelenggara Pengelolaan Muhammadiyah.

c. Penyelenggara Amal Usaha.

${ }^{30}$ Ibid,hlm.10 
Pengesahan pendirian Cabang ditentukan oleh pimpinan wilayah atas usul ranting setelah memperoleh persetujuan pimpinan Daerah. (ART Pasal 6)

3. Daerah adalah kesatuan Cabang dalam satu Kota atau Kabupaten yang terdiri sekurang-kurangnya tiga Cabang (ART Pasal 7). Yang memiliki fungsi, sebagai berikut:

a. Pembinaan, pemberdayaan, dan koordinasi Cabang.

b. Penyelenggaraan, pembinaan dan pengawasan pengelolaan Muhammadiyah.

c. Penyelenggaraan, pembinaan dan pengawasan amal usaha.

d. Perencanaan Program dan kegiatan.

Pengesahan pendirian Daerah ditetapkan oleh Pimpinan Pusat atas usulan Cabang setelah memperhatiakan pertimbangan Pimpinan Wilayah.

4. Wilayah adalah kesatuan daerah di Propinsi yang terdiri atas sekurang-kurangnya tiga daerah yang berfungsi. (ART Pasal 8), yang memiliki fungsi:

a. Pembinaan, pemberdayaan, dan koordinasi Daerah. 
b. Penyelenggaraan, pembinaan dan pengawasan pengelolaan Muhammadiyah.

c. Penyelenggaraan, pembinaan dan pengawasan amal usaha.

d. Perencanaan Program dan kegiatan.

5. Pusat (ART pasal 9), adalah kessatuan Wilayah dalam Negara Republik Indonesia, yang memiliki fungsi:

a. Melakukan pembinaan, pemberdayaan, dan koordinasi wilayah.

b. Penyelenggaraan, pembinaan, dan pengawasan. Pengelolahan Muhammadiyah.

c. Penyelenggaraan, pembinaan dan pengawasan amal usaha.

d. Perencanaan Program dan kegiatan.

F. PEMIKIRAN DAN GERAKAN MUHAMMADIYAH DALAM BIDANG AKIDAH, IBADAH, AKHLAK DAN MU'AMALAH.

Pemikiran dan gerakan Muhammadiyah dalam bidang Akidah dan Tauhid, Ibadah, Akhlak serta Mu'amalah. Terdapat dalam Kandungan Muqaddimah Anggaran Dasar Muhammadiyah.

Muqaddimah Anggaran Dasar Muhammadiyah mengandung 7 (tujuh) pokok pikiran, yaitu: 
1. Pokok Pertama: "Hidup manusia harus berdasar Tauhid (mengEsakan) Allah; ber-Tuhan, beribadah serta tunduk dan taat hanya kepada Allah." Dalam Muqaddimah Anggaran Dasar berbunyi: “Amma ba'du, bahwa sesungguhnya ke-Tuhanan itu adalah hak Allah semata-mata, ber-Tuhan dan berlbadah serta tnduk dan taat kepada Allah adalah satu-satunya ketentuan yang wajib atas tiap-tiap makhluk, terutama manusia."

a. Ajaran Tauhid adalah inti ajaran Islam yang tetap, tidak berubah-ubah, sejak agama Islam yang pertama sampai akhir. (QS. Al-Anbiya':25) seluruh ajaran Islam bertumpu dan memanifestasikan kepercayaan Tauhid. Kepercayaan Tauhid memliki 3 aspek:

1) Kepercayaan dan keyakinan bahwa Allahlah yang kuasa mencipta, memelihara, mengatur, dan menguasai alam semesta.

2) Kepercayaan dan keyakinan bahwa hanya Allah Tuhan yang Haq.

3) Kepercayaan dan keyakinan bahwa hanya Allahlah yang berhak dan wajib disembah (dihambai). Qs.Al-A'raf:54; Muhammad:19; Al-Isra':23

Kepercayaan Tauhid membentuk 2 kesadaran, yaitu: 
1) Kepercayaan terhadap hari akhir, dimana manusia akan mempertanggungjawabkan hidupnya di dunia.

2) Sadar bahwa hidup manusia di dunia ini semata-mata untuk amal sholeh.

Ibadah, artinya taqarrub (mendekatkan diri) kepada Allah dengan mentaati segala perintahnya, menjauhi larangan-Nya dan mengamalkan yang diijinkan. ${ }^{31}$ Ibadah dibagi menjadi dua:

a. Ibadah Umum, yaitu segala amal yang diizinkan Allah.

b. Ibadah Khusus, yaitu apa yang telah ditetapkan Allah perinciannya, tingkah dan tata caranya yang tertentu. (Putusan Majlis Tarjih)

Jadi hidup beribadah ialah hidup untuk mendekatkan diri kepada Allah YMH, dengan melaksanakan ketentuan - ketentuan yang menjadi peraturan-Nya, guna mendapatkan keridlaan-Nya. Wujud hidup merupakan Ibadah yakni taqarrub kepada Allah dengan menunaikan

${ }^{31}$ Hamdan hambali, Ideologi dan Strategi Muhammadiyah.

Yogyakarta.PT. Surya Sarana Utama. 2006.,hlm.13 
amanah-Nya sebagai Khalifah di bumi, membangun dan mengatur dunia serta menciptakan serta memelihara keamanan, ketertiban guna memakmurkan dan mematuhi ketentuan - ketentuan yang menjadi peraturanNya. (QS.Al-An'am:165; QS. Al-Baqara:30; QS.Hud: 61).

Dalam Muhammadiyah, amal ibadah yang bersifat kemasyarakatan, berjuang untuk kebaikan, kebahagiaan dan kesejahteraan masyarakat. Hal inilah amalan ibadah pribadi yang langsung hubungannya kepada Allah SWT.

2. Pokok pikiran kedua, Hidup manusia itu bermasyarakat. Dalam Muqaddimah $A D$ Muhammadiyah berbunyi: " Hidup bermasyarakat itu adalah sunnah (hukum qudrat iradah) Allah atas hidup manusia di dunia ini."

Dalam Muhammadiyah, manusia dengan kehidupannya adalah objek pokok bentuk pengabdiannya kepada Allah Tuhan YME. Sehingga Manusia hidup di dunia tiada artinya bila hidup secara pribadi harus berkelompok (berorganisasi).

3. Pokok pikiran ketiga, dalam Muqoddimah $A D$ Muhammadiyah: " Masyarakat sejahtera, aman, 
damai makmur dan bahagia hanyalah dapat diwujudkan di atas keadilan, kejujuran, persaudaraan dan gotong royong, bertolong menolong dengan bersendi hukum Allah yang sebenar-benarnya, lepas dari pengaruh syaitan dan hawa nafsu."

Jadi Hukum Allah yang satu-satunya dapat dijadikan sendi untuk membentuk pribadi utama dan mengatur kehidupan bermasyarakat menuju hidup bahagia dunia dan akhirat. (QS. Ali-Imaran: 19 dan 85; al-Maidah: 3; Al-Anbiya:107)

4. Pokok Pikiran keempat, dalam Muqaddimah AD Muhammadiyah berbunyi: " menjunjung tinggi hukum Allah lebih dari pada hukum manapun juga adalah kewajiban mutlak bagi tiap-tiap orang yang mengaku berTuhan kepada Allah. Agama Islam adalah Agama Allah yang dibawa oleh sekalian Nabi, sejak Nabi Adam sampai Nabi Muhammad SAW dan diajarkan kepada umatnya masing-masing untuk mendapatkan hidup bahagia dunia dan akhirat, (Qs. Al Hujurat:15, Qs. An-Nur:55).

5. Pokok Pikiran kelima: Perjuangan menegakkan dan menjunjung tinggi agama Islam sehingga terwujud masyarakat Islam yang sebenar-benarnya, hanyalah 
akan dapat berhasil bila dengan mengikuti perjuangan para Nabi.(QS. Al Ahzab: 21)

6. Pokok Pikiran keenam: perjuangan mewujudkan pokok pikiran hanya akan dapat dilaksanakan dengan sebaik-baiknya dan berhasil, bila dengan cara berorganisasi. Organisasi merupakan alat atau cara perjuangan yang sebaik-baiknya. Firman Allah Qs. Ali Imran: 104, berdasarkan surat tersebut uhammadiyah merupakan organisasi yang bersifat gerakan sehingga, memiliki ciri-ciri sebagai berikut:

a. Muhammadiyah sebagai subjek/pimpinan dan masyarakat sebagai objek (yang dipimpin)

b. Dinamis (lincah), maju (progresif), selalu dimuka dan militan.

c. Revolusioner

d. Mempunyai pimpinan yang kuat, cakap, tegas dan berwibawa.

e. Memiliki organisasi yang susunannya lengkap dan selalu up to date.

Sehingga dalam mengambil keputusan dan menentukan tindakan Muhammadiyah berdasarkan pada QS. Syura: 38 
7. Pokok Pikiran Ketujuh: (merupakan kewajiban) pokok pikiran ini menyangkut tujuan dan cita-cita untuk mewujudkan masyarakat adil dan makmur lahir batin yang diridhai Allah, ialah masyarakat Islam yang sebenar-benarnya. Maka diharapkan keberadaan Muhammadiyah bisa menjadi rujukan masyarakat menuju pintu surga dengan ridho Allah.

\section{F. RANGKUMAN}

1. Hakekat Muhammadiyah merupakan gerakan Islam, Dakwah Amar Ma'ruf Nahi Mungkar dan Tajdid, bersumber pada Al-Qur'an dan As-sunnah. Sedangkan Asas Muhammadiyah adalah Islam. Tujuannya adalah menegakkan dan menjunjung tinggi agama Islam sehingga terwujudnya masyarakat Islam yang sebenar-benarnya. Untuk mewujudkan maksud dan tujuan Muhammadiyah tersebut maka, dibentuklah program - program kerja dan kegiatan yang menghasilkan amal usaha - amal usaha sebagai bentuk mewujudkan masyarakat Islam yang sebenarbenarnya.

2. Struktur persyarikatan Muhammadiyah diatur dalam AD Muhammadiyah Bab V pasal 9, yakni: Ranting, Cabang, Daerah, Wilayah dan Pusat. 
3. Keanggotaan Muhammadiyah diatur dalam Anggaran Dasar (AD) Muhammadiyah Bab IV pasal 8 ayat 1: anggota Muhammadiyah terdiri atas, anggota biasa, anggota luar biasa, dan anggota kehormatan.

4. Pemikiran dan gerakan Muhammadiyah dalam bidang Akidah dan Tauhid, Ibadah, Akhlak serta Mu'amalah. Terdapat dalam Kandungan Muqaddimah Anggaran Dasar Muhammadiyah.

\section{G. SOAL LATIHAN}

1. Apakah kepanjangan $\mathrm{MKCH}$ dan apakah maksudnya? Jelaskan!

2. Apakah yang masuk dalam ruang lingkup Identitas Muhammadiyah? Jelaskan!

3. Siapakah yang dimaksud dengan anggota Muhammadiyah? Jelaskan!

4. Bagaimanakah gerakan keagamaan Muhammadiyah?

5. Sebutkan bagaimanakah matan (isi) Muqodimah Anggaran Dasar Muhammadiyah? 


\section{H. DAFTAR PUSTAKA}

Hambali, Hamdan. Ideologi dan strategi

Muhammadiyah. Yogyakarta: Suara Muhammadiyah, 2008.

Mustthafa Kamal Pasha, Ahmad Adaby Darban.

Muhammadiyah Sebagai Gerakan Islam. Yogyakarta: Citra Karsa Mandiri, 2005.

Pimpinan Pusat Muhammadiyah, Anggaran Dasar dan Anggaran Rumah Tangga Muhammadiyah. Yogyakarta: Suara Muhammadiyah, 2005. 


\section{BAB.VI}

\section{MUHAMMADIYAH SEBAGAI GERAKAN ISLAM YANG BERWATAK TAJRID DAN TAJDID}

Nama Mata Kuliah

Semester

SKS

Pertemuan ke-

Lama Jam pertemuan
: AIK 3 (KE-MUHAMMADIYAH-AN)

: III

: 2 sks

$: 6$

$: 2 \times 50$ menit

Kemampuan akhir yang diharapkan:

1. Memahami pengertian tajrid dan Tajdid

2. Memahami model Tajrid dan tajdid Muhammadiyah

3. Memahami model gerakan keagamaan Muhammadiyah

4. Memahami makna gerakan keagamaan Muhammadiyah

5. Memahami gerakan tajdid pada 100 tahun pertama dan 100 tahun ke-2

\section{A. PENDAHULUAN}

\section{B. PENGERTIAN TAJRID DAN TAJDID}

Selain dikenal sebagai gerakan Islam dan gerakan dakwah amar makruf nahi munkar, Muhammadiyah juga dikenal sebagai gerakan tajdid. Istilah tajdid berasal dari bahasa Arab yaitu jaddada, yang berarti memperbaharui atau menjadikan baru. Kata ini pula bentukan dari kata jadda, yajiddu, 
jiddan/jiddatan, artinya sesuatu yang ternama, yang besar, nasib baik dan baru. Bisa juga berarti membangkitkan, menjadikan, (muda, tangkas, kuat) dan dapat pula berarti memperbaharui, memperpanjang izin, dispensasi, kontrak.Dalam kamus Bahasa Indonesia tajdid berarti pembaruan, modernisasi atau restorasi. Orang yang melakukan pembaruan disebut mujaddid.

Sedangkan dari segi istilah, tajdid memiliki dua arti, yaitu (a) pemurnian, dan (b) peningkatan, pengembangan, modernisasi, dan yang semakna dengannya.Tajdid dengan arti pemurnian dimaksudkan sebagai pemeliharaan matan ajaran islam yang berdasarkan dan bersumber pada al-Qur'an dan as-Sunnah as-Shahihah. Sedangkan tajdid dengan arti peningkatan, pengembangan, modernisasi, dan yang semakna dengannya, dimaksudkan sebagai penafsiran, pengamalan, dan perwujudan ajaran Islam dengan tetap berpegang teguh pada al-Qur'an dan as-Sunnah as-Shahihah.

Sifat tajdid yang dikenakan pada gerakan Muhammadiyah di samping berupaya memurnikan ajaran Islam dari berbagai kotoran yang menempel pada tubuhnya, meliputi kotoran tahayul, bid'ah, dan khurafat, juga termasuk upaya Muhammadiyah melakukan berbagai pembaharuan cara-cara pelaksanaan ajaran Islam dalam kehidupan bermasyarakat. 
Istilah tajrid berasal dari bahasa Arab berarti pengosongan, pengungsian, pengupasan, pelepasan atau pengambil alihan. Sedangkan tajrid dalam bahasa Indonesia berarti pemurnian. Istilah ini, tidak se populer ketika menyebut istilah tajdid, sekalipun yang dimaksudkan adalah memurnikan hal-hal yang bersifat khusus. Dari dua istilah tersebut (tajrid dan tajdid), maka dapat diambil suatu kesimpulan yaitu bahwa dalam hal ibadah kita mengambil sikap tajrid, hanya ikut Nabi saw. dan tidakada pembaruan. Sedang dalam muamalah kita dapat melakukan tajdid, yakni melakukan modernisasi dan pembaruan.

\subsection{Model Tajrid Dan Tajdid Muhammadiyah}

Jika kita melihat kembali dokumen awal berdirinya Muhammadiyah, tak satupun yang menjelaskan bahwa Muhammadiyah adalah gerakan tajdid. Dalam Anggaran Dasar pertama disebutkan bahwa maksud dan tujuan Muhammadiyah adalah "menyebarkan pengajaran Kanjeng Nabi Muhammad kepada penduduk Bumiputra, di dalam residensi Yogyakarta. Memajukan hal agama Islam kepada anggota-anggotanya." Rumusan ini menegaskan tentang identitas diri Muhammadiyah sebagai gerakan dakwah amar ma'ruf nahi munkar. Penegasan identitas diri inilah yang membedakan Muhammadiyah dengan gerakan Islam 
semasanya yang umumnya mengikatkan diri pada orientasi ideologi keagamaan tertentu sebagai gerakan reformis (AlIrshad), memberantas bid'ah, khurafat, dan takhayul secara radikal (Persis), dan ahlus sunnah wal jamaah (NU). ${ }^{32}$ Identitas diri Muhammadiyah sebagai gerakan tajdid baru dirumuskan akhir-akhir ini.

Tajdid, yang muncul dalam berbagai ragam gerakan pembaharuan dalam sejarah Islam, merupakan salah satu bentuk implementasi nilai ajaran Islam setelah meninggalnya Nabi. Gerakan tajdid muncul sebagai jawaban terhadap tantangan kemunduran yang dialami dan, atau jawaban terhadap tantangan kemajuan yang dicapai oleh kaum Muslimin. Rekonstruksi tajdid Muhammadiyah dilakukan tidak hanya untuk menjawab kedua tantangan seperti yang disebutkan di atas, tetapi juga didasarkan pada landasan teologis yang menyebutkan perlunya pembaharuan pada setiap seratus tahun. Kedua tantangan di atas bisa dilihat dalam diri Muhammadiyah dan akibat pembaharuan yang telah dilakukannya.

Gerakan tajrid Muhammadiyah didasarkan pada ketidakmurnian ajaran Islam yang berkembang dan dipraktekkan umat Islam. Hal ini terjadi karena bercampurnya

${ }^{32}$ Achmad Jainuri, Ideologi Kaum Reformis Melacak Pandangan Keagamaan Muhammadiyah Periode Awal, (Surabaya: Lembaga Pengkajian Agama dan Masyarakat, 2002), 50-51 
ajaran Islam dengan budaya di masyarakat yang diwarnai oleh tradisi Hindu Budha. Gerakan Tajrid dilaksanakan melalui startegi dakwah. Dakwah merupakan suatu upaya untuk mendorong manusia agar memperbuat kebaikan dan mengikuti petunjuk, menyeru berbuat makruf dan mencegah perbuatan mungkar. Dakwah juga dimaknai sebagai aktifitas mengubah suatu kondisi kepada kondisi lain yang lebih baik lagi, yang dilakukan dengan sadar, sengaja, dan terencana. ${ }^{33}$ TajridMuhammadiyah dilaksanakan dengan semangat kembali pada Al-Quran dan Sunnah Nabi (al-ruju' ila al Qur'an wal alSunnah) guna meluruskan pemahaman agama yang bersifat serba taklid dan bermuatan kemusyrikan, tahayul, dan bid'ah ke paham Islam yang otentik atau murni bersumber pada AlQuran dan Sunnah Nabi yang sahiha/maqbulah. Bagi Muhammadiyah, Islam tidak ada sumber ajarannya yang otentik kecuali pada Al-Quran dan Sunnah Nabi yang sahih atau yang dapat diterima. Adapun pandangan madzhab, ulama, dan sejenisnya bersifat paham yang dasar dan subtansi kebenarannya harus dirujuk dan diuji oleh Al-Quran dan Sunnah Nabi, bukan sebaliknya. Qaul atau pendapat ulama jangan sampai menguburkan dan mengaburkan pandangan Al-Quran dan Sunnah Nabi yang maqbulah, apalagi

${ }^{33}$ Rosyad Sholeh, Manajemen Dakwah Muhammadiyah, (Yogyakarta: Suara Muhammadiyah, 2010), 47 
menempatkannya sebagai kebenaran mutlak yang harus diikuti secara taklid atau tanpa kritis.

\section{MODEL DAN MAKNA GERAKAN KEAGAMAAN}

\section{MUHAMMADIYAH}

Pergerakan Muhammadiyah pada hakikatnya merupakan perwujudan dari spirit dan pesan Islam yang berkemajuan. Muhammadiyah mengajarkan Islam berkemajuan yang menjadi motor pembaruan pemahaman agama yang rasional dan terbuka pada kemajuan ilmu pengetahuan, dengan tetap kokoh dalam pondasi Islam yang auntetik, Muhammadiyah mengembangkan lembaga pendidikan, kesehatan, dan sosial sebagai pranata baru untuk pemenuhan kebutuhan dan pemecahan masalah kemasyarakatan berbasis nilai-nilai Islam yang mencerahkan. Metode dakwah yang dikembangkan Muhammadiyah juga menjadi cetak biru bagi pengembangan dakwah Islam modern di Indonesia. Islam yang dihadirkan Muhammadiyah berkarakter tengahan atau moderat (mutawasithah) dan menyejarah sehingga melahirkan Indonesia yang Islamis atau menjadi bangsa Muslim. ${ }^{34}$

${ }^{34}$ Achmad Jainuri, Ideologi Kaum Reformis Melacak Pandangan Keagamaan Muhammadiyah Periode Awal, (Surabaya: Lembaga Pengkajian Agama dan Masyarakat, 2002), hal. 60 
Gerakan dakwah dan tajdid yang telah dilakukan Muhammadiyah dalam kurun satu abad dapat dirinci sebagai berikut: ${ }^{35}$

Pertama, memperbarui paham Islam. Muhammadiyah dengan semangat kembali pada Al-Quran dan Sunnah Nabi (al-ruju' ila al Qur'an wal al-Sunnah) telah berhasil meluruskan pemahaman agama yang bersifat serba taklid dan bermuatan kemusyrikan, tahayul, dan bid'ah ke paham Islam yang otentik atau murni bersumber pada Al-Quran dan Sunnah Nabi yang sahiha/maqbulah. Bagi Muhammadiyah, Islam tidak ada sumber ajarannya yang otentik kecuali pada Al-Quran dan Sunnah Nabi yang sahih atau yang dapat diterima. Adapun pandangan madzhab, ulama, dan sejenisnya bersifat paham yang dasar dan subtansi kebenarannya harus dirujuk dan diuji oleh Al-Quran dan Sunnah Nabi, bukan sebaliknya. Qaul atau pendapat ulama jangan sampai menguburkan dan mengaburkan pandangan Al-Quran dan Sunnah Nabi yang maqbulah, apalagi menempatkannya sebagai kebenaran mutlak yang harus diikuti secara taklid atau tanpa kritis.

Kedua, memperbarui alam pikiran kearah kemajuan atau kemodernan. Ketika Muhammadiyah lahir umat Islam

${ }^{35}$ Haedar Nashir, Muhammadiyah Abad Kedua, (Yogyakarta: Suara Muhammadiyah, 2011), 74 
khususnya dan masyarakat Indonesia berada dalam keadaan tradisional, yakni terkungkung oleh tradisi yang menunjukkan keadaan dan sikap yang tertinggal, terbelakang, dan jauh dari kemajuan. Umat Islam saat itu identik dengan kemiskinan, kolot, dan anti kemajuan. Muhammadiyah hadir melakukan modernisasi alam pikiran, memperbarui cara berpikir, bersikap, dan bertindak yang mengarah pada kemajuan hidup. Bahwa menjadi muslim itu harus terbuka, maju, gagah dan sejajar dengan bangsa lain yang telah maju. Hidup menjadi modern dengan tetap berkepribadian muslim merupakan hal positif dan bukanlah meniru orang kafir hanya karena yang modern itu Barat dan Barat itu dianggap kafir. Muhammadiyah mendobrak tradisonalitas yang membuat umat Islam dan masyarakat terkungkung dalam serba keterbelakangan. Tidak tepat anggapan yang menuding Muhammadiyah membabat hal-hal tradisional seolah-olah tanpa visi dan tujuan.

Ketiga, membangun sistem pendidikan Islam modern. Muhammadiyah diakui sebagai organisasi Islam yang paling menonjol dalam amal usaha pendidikan. Pendidikan bahkan menjadi ciri penting bahkan melekat dengan gerakan Muhammadiyah. Lembaga pendidikan dari tingkat dasar hingga perguruan tinggi dimiliki Muhammadiyah, termasuk Taman Kanak-Kanak Aisyiyah Busthanul Athfal yang tersebar 
di seluruh tanah air. Ciri penting dan merupakan kepeloporan Muhammadiyah dari lembaga pendidikan yang dirintis dan dikembangkan adalah sistem pendidikan Islam yang diperkenalkan Muhammadiyah memadukan pendidikan agama dan pendidikan umum dalam satu kesatuan sistem, baik dalam bentuk sekolah atau perguruan umum maupun madrasah dan pondok pesantren.

Lembaga pendidikan Islam modern yang dipelopori Muhammadiyah sejak awal kelahirannya merupakan alternatif dari sistem pendidikan Islam tradisional yang waktu itu hanya memperkenalkan pendidikan agama secara khusus, yang tidak responsif terhadap tantangan dan perkembangan zaman. Apa yang dirintis Muhammadiyah tersebut pada awalnya ditanggapi negatif oleh kalangan Islam tradisional karena memakai sistem sekolah model Barat, tetapi lama kelamaan diterima secara luas bahkan di belakang hari ditiru dan menjadi sistem pendidikan yang berlaku umum di lingkungan umat Islam. dalam memperbarui sistem dan pandangan pendidikan Islam ke arah yang modern.

Keempat, gerakan Al-Ma'un dan Penolong Kesengsaraan Umum. Muhammadiyah termasuk organisasi yang menonjol dalam gerakan pelayanan sosial dan kesehatan, bahkan boleh disebut sebagai pelopor. Tidak ada gerakan pembaruan Islam di dunia muslim yang merintis dan mengembangkan gerakan 
pelayanan sosial dan kesehatan secara melembaga yang hingga kini terus berkembang kecuali Muhammadiyah. Bagi Muhammadiyah amal usaha di bidang pelayanan sosial dan kesehatan itu bukan sekadar karitatif atau kedermawan, tetapi merupakan gerakan pemberdayaan sebagai perwujudan dari semangat teologi Al-Ma'un yang dilembagakan melalui Penolong Kesengsaraan Oemoem (PKO). Bahkan melayani kaum miskin, anak yatim, dan kaum dhu'afa lainnya merupakan panggilan keagamaan sebagai wujud dari konsistensi menjalani agama, sebaliknya menelantarkan dan tidak peduli dengan kaum lemah itu merupakan bentuk dari pendustaan terhadap agama Islam. Melalui Al-Ma'un dan PKO, Muhammadiyah menghadirkan Islam sebagai gerakan pembebasan pemberdayaan masyarakat.

Gerakan PKO merujuk pada peristiwa Muhammadiyah generasi awal ketika Kyai Haji Ahmad Dahlan mengajarkan surat Al-Ma'un kepada murid-muridnya hingga berulang-ulang dalam tempo yang lama sampai membuat jenuh dan bosan. Ketika muridnya bertanya setengah protes kenapa Al-Ma'un terus diajarkan padahal mereka merasa sudah hafal dan mengerti. Kyai Dahlan justru bertanya apakah kalian sudah mengerti? Jika sudah mengerti, ambillah anak yatim dan miskin untuk diasuh dan dipelihara di keluarga masing- 
masing. Sejak itu lahirlah gerakan Al-Ma'un untuk memelihara anak yatim dan miskin, yang kemudian dikenal dengan gerakan Al-Ma'un. Gerakan Al-Ma'un itu kemudian hari, pada tahun 1922, dilembagakan menjadi pendirian rumah sakit, panti asuhan, rumah miskin, penanggulangan bencana, dan lembaga pelayanan sosial di bawah Bahagian Penolong Kesengsaraan Oemoem (PKO) Muhammadiyah.

Kelima, membentengi umat Islam dari berbagai ancaman luar. Muhammadiyah tanpa menggembor-gemborkan diri melalui berbagai gerakan amal usaha dan pemberdayaannya secara langsung maupun tidak langsung sebenarnya telah memagari atau membentengi umat dari segala bentuk ancaman dari luar, termasuk ancaman pemurtadan atau perpindahan agama. Namun langkah yang dilakukan Muhammadiyah bersifat elegan, yakni tidak dengan cara konfrontasi dengan pihak lain. Muhammadiyah melakukannya dengan pendekatan kultural dan karya nyata, sehingga tampil secara kompetitif dan objektif. Kyai Dahlan bahkan mengajak pendeta untuk berdialog dan berdebat soal kebenaran agama, dengan tetap santun dan cerdas.

Keenam, memelopori kemajuan perempuan Islam ke ruang publik. Muhammadiyah melalui gerakan Aisyiyah yang dilahirkannya pada tahun 1917 merupakan satu-satunya gerakan pembaruan Islam di dunia muslim yang berani 
melakukan terobosan dengan menghadirkan gerakan perempuan Islam ke ruang publik. Langkah terobosan tersebut dikatakan berani karena seakan melawan dua arus, yaitu paham keagamaan yang masih bias jender terhadap perempuan dan budaya masyarakat yang menganut sistem patriarkhi, yang melahirkan diskriminasi dan dominasi terhadap perempuan. Muhammadiyah tanpa terjebak pada paham emansipasi yang sekuler-liberal, telah menghadirkan pembaruan tatanan yang berkeadilan antara laki-laki dan perempuan dalam sistem sosial muslim yang demokratis dan berakhlak utama.

Muhammadiyah melalui gerakan Aisyiyah sejak tahun 1917 juga telah berkiprah dalam pemberdayaan perempuan sekaligus melakukan pembaruan Islam dengan menjadikan perempuan sebagaimana halnya laki-laki memiliki martabat dan peran yang sama mulianya dalam kehidupan. Aisyiyah sebagai organisasi otonom Muhammadiyah dan gerakan perempuan Indonesia tertua yang berdiri tahun 1917 memiliki peran sentral dalam Kongres Wanita I tahun 1928 yang bersejarah itu. Sebelas tahun sebelum Kongres itu lahir, Aisyiyah bahkan telah melakukan kepeloporan dan peran historis yang monumental dalam memprakarsai kebangunan perempuan Islam pada khususnya dan perempuan Indonesia pada umumnya. Aisyiyah bersama Muhammadiyah dengan 
misi dakwah Islam yang diyakininya, melakukan gerakan melawan kolonialisme, diskriminasi pendidikan, membebaskan rakyat dari kebodohan dan kejumudan, dan membangun kehidupan baru yang makmur dan martabat.

\section{GERAKAN TAJDID PADA 100 TAHUN PERTAMA DAN 100}

\section{TAHUN KE-2}

Muhammadiyah dalam perjalanan usianya satu abad dapat dikatakan telah melewati dinamika zaman yang penuh perjuangan suka maupun duka dalam rentang tiga zaman yaitu era perjuangan kemerdekaan di masa kolonial, era setelah kemerdakaan di masa Orde Lama dan Orde Baru, dan era baru Reformasi yang masih akan berlangsung penuh pertaruhan.

Ketika lahir, Muhammadiyah dihadapkan dengan kondisi masyarakat yang sangat memprihatinkan akibat kolonialisasi Belanda. Ketimpangan praktik dualisme pendidikan, yaitu antara pendidikan Belanda yang sekuler untuk anak-anak dari kalangan Priyayi dan Belanda saja dan pendidikan pesantren yang sangat tradisional untuk penduduk pribumi dan rakyat jelata. Tantangan lain yang dihadapi Muhammadiyah adalah kemiskinan, kristenisasi, serta tradisionalisme dan penyimpangan praktek beragama. Kondisi umat Islam pada 
saat itu menjadi sasaran bagi K.H. Ahmad Dahlan dan Muhammadiyah untuk melakukan gerak dakwahnya.

Upaya yang ditempuh Muhammadiyah untuk mengatasi masalah tersebut diwujudkan dalam gerakan pembaharuan pemahaman agama, reformasi sistem pendidikan Islam, pengembangan pranata pelayanan-pelayanan sosial dan pemberdayaan masyarakat berbasis Penolong Kesengsaraan Oemoem (PKO), memajukan peran perempuan muslim (Aisyiyah) di ruang publik, pengorganisasian zakat dan haji, merintis taman pustaka dan publikasi, tabligh yang mencerdaskan, dan mengembangkan amaliah Islami yang memajukan kehidupan. Dalam kehidupan nasional Muhammadiyah telah berkiprah untuk pergerakan kebangkitan kebangsaan, meletakkan pondasi negara-bangsa yang berlandaskan Pancasila dan UUD 1945, menegakkan Negara Republik Indonesia agar tetap berada dalam koridor konstitusi dan cita-cita kemerdekaan, melakukan kerja-kerja kemasyarakatan dan usaha-usaha modernisasi sosial untuk mencerdaskan kehidupan bangsa. Muhammadiyah juga menjadi pilar penting kekuatan masyarakat madani (civil society) dan memelopori lahirnya era baru Indonesia yang demokratis, menghargai hak asasi manusia dan berwawasan kemajemukan. 


\section{Abad Ke-21}

Muhammadiyah dalam pergantian abad dari kelahirannya akan memasuki abad baru (abad ke-2 dari perjalanannya) sehinga dari titik abad tersebut Muhammadiyah akan melintasi zaman dengan segala tantangan, masalah dan harapan baru ketika dunia berada dalam fase post-modern dan era globalisasi dengan seribusatu dinamikanya. Dalam menghadapi pergantian abad menuju fase baru itu Muhammadiyah dituntut merumuskan ulang orientasi dan aktualisasi dakwah dan tajdid yang menjadi fokus gerakannya, sehingga mampu melampaui dan melintasi zaman yang dilalui dan dihadapinya dengan penuh kesiapan untuk menghadirkan risalah Islam sebagai rahmatan lil-alamin.

Abad ke-21 ketika Muhammadiyah memasuki fase kedua sungguh merupakan dunia baru yang ditandai oleh perubahan-perubahan sosial yang luas dan spektakuler. Relasi antar manusia tidak lagi bersifat konvensional dalam hubungan sosial langsung, tetapi memasuki era relasi Cyber World atau Cyber-Connected dalam latar dunia maya didukung teknologi informasi yang luar biasa dan mempengaruhi pola hidup manusia sejagad. Perubahanperubahan sosial dalam berbagai aspek berkembang pesat serba melampaui yang tidak jarang manusia sendiri kehilangan kesempatan untuk beradaptasi sehingga 
melahirkan tekanan mental dan dis-orientasi (hilang arah) yang disebut Alvin Toffler sebagai Future shock atau kejutan masa depan.

Muhammadiyah pada abad kedua meneguhkan komitmen gerakannya sebagai pembawa misi Islam yang berkemajuan untuk berperan lebih proaktif dalam menyelesaikan masalah dan menjawab tantangan zaman, serta hadir di barisan depan untuk menjadi kekuatan perubahan yang bersifat transformatif menuju keterbangunannya peradaban umat manusia yang utama. Isu-isu strategis yang dibahas dan dihasilkan dalam Muktamar ke-46 terbilang maju dan progresif, yang menggambarkan keluasan pandangan dalam menghadapi masalah-masalah mutakhir.

Dalam "Pernyataan Pikiran Muhammadiyah Abad Kedua" hasil Muktamar Satu Abad tahun 2010 di Yogyakarta secara resmi disebutkan bahwa "Muhammadiyah pada abad kedua berkomitmen kuat untuk melakukan gerakan pencerahan" ${ }^{36}$. Muktamar Muhammadiyah ke-46 itu pun bahkan menginventarisasi masalah-masalah krusial yang akan dihadapi dan menjadi tantangan bagi Muhammadiyah untuk menyelesaikannya, yaitu sebagai berikut:

${ }^{36}$ Haedar Nashir, Muhammadiyah Sebagai Gerakan Pencerahan, (dalam Suara Muhammadiyah edisi no. 15 tahun ke-100), Yogyakarta: Suara Muhammadiyah, 2015, 23. 


\section{a. Krisis Kemanusiaan Modern}

Kehidupan masyarakat modern abad ke-21 menunjukkan kemajuan yang luar biasa terutama di bidang pemikiran, ilmu pengetahuan dan teknologi, dan aspek-aspek lainnya yang mengantarkan manusia di planet ini berada dalam peradaban yang tinggi. Namun bersamaan dengan itu terjadi kecenderungan hidup yang serba ekstrem yang melahirkan krisis kemanusiaan modern. Manusia modern mengalami lost of soul (kegersangan ruhani), disorientasi makna, anomali (penyimpangan moral dan sosial, kekerasan, dan future shock (kejutan masa depan). Masalah-masalah tersebut timbul sebagai akibat dari orientasi hidup yang serba nasionalinstrumental yang melahirkan manusia serba modular dan kehilangan makna-makna ruhaniah yang otentik. Bersamaan dengan itu kebudayaan modern memiliki sisi negatif berupa penghambaan yang berlebihan terhadap materi (materialisme), kesenangan inderawi (hedonisme), dan peniadaan nilai-nilai (nihilisme).

\section{b. Krisis Pangan dan Energi}

Saat ini dunia mengalami ancaman ketahanan pangan (food security) yang sangat serius karena terbatasnya ketersediaan sumber-sumber dan bahan makanan karena keterbatasan lahan, kekeringan dan ledakan jumlah penduduk. Kriss energi 
dan pangan yang berkelanjutan merupakan masalah yang sangat mengancam masa depan umat manusia dan kemanusiaan. Semakin menipisnya ketersediaan sumber daya energi alam yang tidak terbarukan, tertuama minyak bumi, batubara dan gas yang menimbulkan kompetisi terhadap akses energi yang tidak sehat sebagai salah satu penulut ketegangan, konflik, peperangan dan hegemoni negaranegara kaya atas kedaulatan ekonomi dan politik negaranegara miskin.

\section{c. Krisis Ekonomi Global}

Globalisasi ekonomi telah menyebabkan semakin tingginya tingkat keterkaitan ekonomi antar negara. Krisis keuangan tahun 2008-2009 yang berawal dari krisis kredit perumahan di Amerika Serikat telah menjalar ke hampir seluruh dunia. Pelajaran yang bisa dipetik dari kejadian ini adalah bahwa di antara negara-negara yang menganut sistem pasar bebas, kesuksesan ekonomi tidak mudah untuk menjalar ke negara lain, sementara kegagalan ekonomi sangat mudah bahkan tak tertahankan untuk menjalar ke negara lain. Disamping itu, kesuksesan sektor swasta tidak mudah untuk dirembetkan manfaatnya ke sektor negara tetapi kegagalan sektor swasta terutama besar, sangat mudah menjadi tanggungan negara. 


\section{d. Krisis Lingkungan dan Perubahan Iklim}

Kerusakan lingkungan dan perubahan iklim berakibat pada menurunnya jumlah dan kualitas produksi hasil pertanian dan kelautan yang berdampak sistemik terhadap menurunnya pendapatan petani, nelayan dan masyarakat yang bekerja pada dua sektor tersebut. Jumlah penganggur dan orang miskin bertambah. Kerusakan alam telah berdampak pada menurunnya daya tahan tubuh tingkat kesehatan dan penyebaran penyakit endemi dan pandemi. Meskipun kerusakan alam dan dampak kerusakan yang ditimbulkannya sudah terlihat jelas pemahaman dan kesadaran masyarakat masih sangat rendah karena kurangnya sosialisasi oleh pemerintah dan para pemangku kepentingan. Masalah lingkungan hidup dan pemanasan global tidak hanya terbatas di kalangan elit, bahkan telah menjadi ladang bisnis dikalangan elit dan negara.

\section{e. Islamofobia}

Pasca peristiwa bom "11 September 2001", kaum muslim diberbagai penjuru dunia menghadapi gelombang baru "Islamofobia" yang terus berkembang secara masif dan sistemik. Islamofobia adalah sebuah wawasan dan pandangan dunia yang disebabkan oleh ketakutan dan kebencian tidak berdasar terhadap Islam. yang muncul melalui praktik-praktik 
pengasingan dan diskriminasi terhadap kaum muslimin dalam berbagai bidang kehidupan. Secara ideologis, Islamofobia muncul dalam bentuk penilaian serta penggambaran negatif terhadap Islam yang dipersepsikan sebagai agama yang tidak rasional, primitif, dan anti kemajuan hingga mengobarkan kekerasan dan mendukung atau apresiatif terhadap terorisme. Islamofobia dimanifestasikan dalam bentuk miskonsepsi atau penyamaan makna jihad dengan terorisme, penggambaran negatif tentang ajaran Islam dan intoleransi umat Islam di media massa, pelecehan terhadap Nabi dan Kitab Suci, kebijakan yang diskriminatif terhadap imigran muslim, hingga semangat dan sikap rasisme anti umat Islam sebagai golongan minoritas yang berbeda dengan kelompok mayoritas.

\section{f. Migrasi Global}

Migrasi global merupakan fenomena sosial yang diakibatkan oleh industrialisasi, kemajuan teknologi transportasi, keamanandan kekerasan. Masyarakat bermigrasi dari suatu negara ke negara lainnya untuk meningkatkan kesejahteraan hidup, mendapatkan rasa aman dan mencari pengalaman. Secara alamiah, migrasi global melahirkan percampuran etnis akumulasi dan akulturasibudaya. Tetapi, lambat laun, migrasi global menimbulkan perubahan komposisi penduduk yang 
langsung atau tidak langsung menimbulkan masalah persatuan bangsa seperti sentimen antara pendatang dengan penduduk asli,identitas kebudayaan, kewargaan dan masalah sosial politik lainnya.

\section{g. Konflik Antarperadaban}

Tidak dapat dipungkiri, kekerasan bernuansa agama yang terjadi di berbagai kawasan dunia telah menimbulkan sentimen dan rasa tidak suka diantara penduduk agama, khususnya pemeluk agama besar dunia: Islam, Kristen, Yahudi, Hindu dan Budha. Globalisasi yang ditandai oleh kemajuan teknologi informasi yang menghilangkan batas-batas geografis antar negara membuat "benturan" antar budaya dan peradaban tidak terhindarkan. Fundamentalisme agama dan kebudayaan berkemabang di hampir semua agama dan kebudayaan. Pada sisi lainnya dialog dan kerjasama antar iman (interfaith) dan antar peradaban (intercivilization) berkembang dengan baik sebagai jawaban dan usaha positif memecahkan berbagai masalah keagamaan dan kebudayaan. Muhammadiyah sangat mendukung dan berperan serta dalam prakarsa dan kegiatan dialog yang terbuka, tulus dan bersahabat. Muhammadiyah menghimbau agar dialog yang sudah diselenggarakan oleh negara dan masyarakat dapat ditingkatkan ke arah kerjasama kemanusiaan yang konkrit 
untuk menciptakan perdamaian, keadilan dan kesejahteraan bersama (common good) tidak terbatas pada elit pemimpin agama tetapi juga masyarakat akar rumput.

\section{h. Hegemoni dan Paradoks Politik Global}

Perkembangan politik global ditandai oleh semakin kuat dan meluasnya demokratisasi, penegakkan hak asasi manusia, dan berbagai dialog antarperadaban. tetapi diakui terjadi paradoks dimana negara-negara maju khususnya Amerika Serikat semakin menunjukkan standar ganda, disatu piha menjadi polisi dunia untuk dan atas nama demokrasi mengawasi bahkan menindak negara-negara sedang berkembang yang tidak menjalankan poitik demokrasi, penegakkan hak asasi manusia, dan menjalankan pemerintahan yang demokratik. Namun pada saat yang sama bertindak sewenang-wenang dalam menjalankan politik luar negerinya seperti menginvasi Irak, mendukung dan membiarkan Israel sewenang-wenang dalam menindas bangsa Palestina, mengintimidasi Iran, terlibat jauh dalam campurtangan menentukan nasib bangsa Afghanistan, dan kebijakan-kebijakan politik luar negeri lainnya yang hegemoni. Perkembangan lain ditunjukkan oleh hampir kebanyakan negara-negara Barat, disatu pihak begitu peduli tentang demokrasi dan HAM, tetapi tidak memberi ruang gerak yang leluasa bagi muslim di negara-negara 
tersebut untuk menjalankan agamanya termasuk dalam memakai jilbab.

\section{i. Kemiskinan Dunia}

Di dunia ini masih terdapat jumlah kaum miskin sekitar 200 juta yang tersebar di negara-negara sedang berkembang, termasuk 32,5 juta di Indonesia yang berada di bawah garis kemiskinan. Padahal kebijakan politik dan ekonomi dunia selalu mengumandangkan pentingnya kesejahteraan/kemakmuran hidup bangsa-bangsa. Terjadi paradoks bahwa ekonomi dunia semakin dikuasai oleh sistem ekonomi kapialis dalam mazhab kapitalisme dan neoliberalisme global, yang dalam prektiknya menimbulkan kesenjangan yang tinggi antara kelompok yang kaya untuk semakin kaya dan kaum miskin kian miskin. Praktik ekonomi kapitalis dan neoliberal cenderung memarjinalkan kaum miskin, dhu'afa, dan mustadh'afin. Inilah paradoks politik dan ekonomi global yang melahirkan proses pemiskinan.

Dengan demikian dalam memasuki abad kedua perjalanannya, Muhammadiyah penting untuk menyadari sejumlah tantangan yang menghadang di depan. Dalam menghadapi tantangan baru yang kompleks dan berat itu Muhammadiyah sebagaimana perjuangan Islam dan lainnya 
dimuka bumi itu dituntut interopeksi dan senantiasa mengembangkan kemampuan untuk menghadapinya.

\section{c. Agenda Abad Kedua}

Muhammadiyah dari segi pemikiran maupun strategi telah menetapkan langkah yang tepat untuk memasuki abad kedua sebagai era baru. Sejalan dengan karakter dirinya sebagai gerakan dakwah dan tajdid yang mencerahkan, maka Muhammadiyah mendeklarasikan diri untuk memasuki abad kedua dengan mencanangkan Gerakan Pencerahan. Seluruh gerakan Muhammadiyah dalam berbagai bidang yang dipilih dan dilakukannya harus berbasis, berkarakter, berorientasi pada pencerahan atau tanwir yang mengandung tiga elemen aspek dan proses yaitu pembebasan, pemberdayaan, dan pemajuan kehidupan. Inilah model dan strategi perubahan yang bersifat transformasi, sebagai kelanjutan dari strategi revitalisasi yang dilakukan sebelumnya. Namun gerakan yang bersifat transformasi itu, sebagai bentuk dan strategi perubahan yang lebih progresif, tidaklah sekedar perubahan progresif tetapi harus mengandung nilai-nilai pencerahan yang berbasis pada ajaran Islam yang berkemajuan sebagaimana yang menjadi pandangan Muhammadiyah. Maka, lahirlah pilihan strategi transformasi dengan tema Gerakan Pencerahan. 
Gerakan pencerahan dimaknai sebagai gerakan praksis Islam yang berkemajuan untuk membebaskan, memberdayakan, dan memajukan kehidupan. Bagi Muhammadiyah, sekedar toleransi, sopan, dan ramah saja tidak cukup. Namun Islam harus hadir dan menyediakan jawaban atas berbagai persoalan dan tantangan zaman, terutama persoalan yang menyangkut kemiskinan, kebodohan, ketertinggalan, ketertindasan, dan ketimpangan sosial yang lain.

\section{G. RANGKUMAN}

1. Istilah tajdid berasal dari bahasa Arab yaitu jaddada, yang berarti memperbaharui atau menjadikan baru. Kata ini pula bentukan dari kata jadda, yajiddu, jiddan/jiddatan, artinya sesuatu yang ternama, yang besar, nasib baik dan baru. Dalam kamus Bahasa Indonesia tajdid berarti pembaruan, modernisasi atau restorasi. Orang yang melakukan pembaruan disebut mujaddid.

2. Secara istilah, tajdid memiliki dua arti, yaitu (a) pemurnian, dan (b) peningkatan, pengembangan, modernisasi, dan yang semakna dengannya. Tajdid dengan arti pemurnian dimaksudkan sebagai pemeliharaan matan ajaran Islam yang berdasarkan dan bersumber pada al-Qur'an dan as-Sunnah as-Shahihah. 
Sedangkan tajdid dengan arti peningkatan, pengembangan, modernisasi, dan yang semakna dengannya, dimaksudkan sebagai penafsiran, pengamalan, dan perwujudan ajaran Islam dengan tetap berpegang teguh pada al-Qur'an dan as-Sunnah asShahihah.

3. Istilah tajrid berasal dari bahasa Arab berarti pengosongan, pengungsian, pengupasan, pelepasan atau pengambil alihan. Sedangkan tajrid dalam bahasa Indonesia berarti pemurnian, yakni memurnikan hal-hal yang bersifat khusus.

4. Tajdid Muhammadiyah muncul dalam berbagai ragam gerakan pembaharuan dalam upaya mengimplementasikan nilai ajaran Islam. Gerakan tajdid adalah sebagai jawaban terhadap tantangan kemunduran yang dialami dan, atau jawaban terhadap tantangan kemajuan yang dicapai oleh kaum Muslimin.

5. Gerakan tajrid Muhammadiyah didasarkan pada ketidakmurnian ajaran Islam yang berkembang dan dipraktekkan umat Islam. Gerakan Tajrid dilaksanakan melalui strategi dakwah yang multidimensional dengan semangat kembali pada Al-Quran dan Sunnah as-Shahihah (al-ruju' ila al Qur'an wal al-Sunnah) 
6. Gerakan dakwah dan tajdid yang telah dilakukan Muhammadiyah dalam kurun satu abad adalahmemperbarui paham Islam, memperbarui alam pikiran kearah kemajuan atau kemodernan, membangun sistem pendidikan Islam modern,gerakan Al-Ma'un dan Penolong Kesengsaraan Umum, membentengi umat Islam dari berbagai ancaman luar,memelopori kemajuan perempuan Islam ke ruang publik.

7. Gerakan tajdid Muhammadiyah pada 100 tahun pertama dan 100 tahun kedua adalah berbeda didasarkan pada perbedaan tantangan yang dihadapi pada kedua masa tersebut. Tantangan pada 100 tahun pertama adalah kemiskinan, kebodohan, penjajahan, dan kristenisasi. Tantangan pada 100 tahun kedua meliputi krisis multidimensi, islamofobia, migrasi global, konflik antarperadaban, hegemoni dan paradoks politik global, kemiskinan dunia

8. Agenda Muhammadiyah memasuki abad kedua adalah mencanangkan Gerakan Pencerahan sebagai gerakan praksis Islam yang berkemajuan untuk membebaskan, memberdayakan, dan memajukan kehidupan sebagai jawaban atas berbagai persoalan dan tantangan zaman 


\section{H. LATIHAN SOAL}

1. Jelaskan pengertian tajrid dan Tajdid

2. Bagaimana model tajrid dan tajdid yang dilakukan Muhammadiyah

3. Jelaskan model gerakan keagamaan Muhammadiyah pada abad pertama usianya

4. Jelaskan perbedaan tantangan yang dihadapi Muhammadiyah pada 100 tahun pertama dan 100 tahun kedua

5. Rancangan apa yang disusun Muhammadiyah untuk melanjutkan geraknya pada abad kedua?

\section{REFERENSI}

Jainuri, Achmad. Ideologi Kaum Reformis Melacak Pandangan Keagamaan Muhammadiyah Periode Awal. Surabaya: Lembaga Pengkajian Agama dan Masyarakat. 2002

Nashir, Haedar. Muhammadiyah Sebagai Gerakan Pencerahan (dalam Suara Muhammadiyah edisi no. 15 tahun ke-100), Yogyakarta: Suara Muhammadiyah. 2015

Nashir, Haedar. Muhammadiyah Abad Kedua. Yogyakarta: Suara Muhammadiyah. 2011

Sholeh,Rosyad.Manajemen Dakwah Muhammadiyah. Yogyakarta: Suara Muhammadiyah. 2010 


\section{BAB. VII \\ MUHAMMADIYAH SEBAGAI GERAKAN SOSIAL}

Mata Kuliah

: Al-Islam dan Kemuhammadiyahan 3

Capaian Pembelajaran : Mahasiswa Mampu menganalisis ajaran sosial Kemanusiaan Muhammadiyah, memahami bentuk dan gerakan Muhammadiyah, mengetahui revitalisasi gerakan sosial Muhammadiyah.

Alokasi Waktu

: $2 \times 50$ menit

Pertemuan ke

$: 8$

Indikator

1. Teologi Al-Ma'un (ajaran s kemanusiaan Muhammadiyah)

2. Bentuk dan gerakan kemanusiaan Muhammadiyah

3. Revitalisasi Gerakan Sosial Muhammadiyah

\section{A. PENDAHULUAN}

pada bab ini akan dibahas mengenai teologi Al-Ma'un (ajaran Sosial Kemanusiaan Muhammadiyah), bentuk dan gerakan sosial Kemanusiaan yang dilakukan Muhammadiyah. serta Revitalisasi gerakan sosial Muhammadiyah. diharapkan mahasiswa mampu menganalisis teologi al-ma'un yang dikembangkan Muhammadiyah dalam gerakan sosial kemanusiaan, mengetahui bentuk gerakan sosial kemanusiaan Muhammadiyah serta, memahami revitalisasi gerakan kemanusiaan Muhammadiyah. 


\section{B. TEOLOGI AL-MA'UN (AJARAN SOSIAL KEMANUSIAAN MUHAMMADIYAH)}

Pemahaman teologi Al-Ma'un berawal dari setiap pengajian rutin Subuh yang dilakukan KH. Ahamd Dahlan. Kiai Dahlan mengajarkan Tafsir Surat Al-Ma'un secara berulangulang selama berhari-hari tanpa menggantinya dengan surat lain. sampai membuat murid-muridnya bingung mengapa Kiai tidak mengajari kita surat yang lain, salah satu murid beliau bernama Sudjak bertanya, "mengapa bahan pengajian kita tidak bertambah dan hanya mengulang-ulang surat AlMa'un?" (Munir Mulkan: 2007)

Mendengar pertanyaan tersebut Kiai Dahlan balik bertanya kepada Muridnya, “Apakah mereka sudah benar benar mengerti akan maksud Surat Al-Ma'un". Serentak murid - murid menjawab mereka bukan hanya mengerti tapi sudah hafal. Kiai lalu bertanya lagi "Apakah sudah hafal itu juga sudah mengamalkannya?", Para murid bingung dan menjawab "apanya yang diamalkan, bukannya surat AlMa'un yang Kiai ajarkan sudah seringkali dibaca saat shalat. Kiai menjawab" bukan itu yang dimaksud diamalkan, tapi apa yang sudah dipahami seharusnya dipraktikkan dan dikerjakan." karena itu Kiai Dahlan memerintahkan para muridnya mencari orang miskin disekitar tempat tinggalnya masing-masing, jika mereka menemukan orang miskin dan 
anak yatim agar dibawah pulang ke rumah masing-masing dan dimandikan dengan sabun dan sikat gigi, diberi pakaian yang baik, diberi makan dan minum, serta tempat tidur yang layak. maka pegajian ditutup beliau dan para murid disarankan segera melaksanakan anjuran beliau.

Dalam setiap ceramah dan pengajian, Kiai Ahmad Dahlan terus-menerus menyerukan agar setiap orang yang mampu bersedia memenuhi hak -hak dan berlaku adil kepada orang miskin dan para fakir, anak yatim, orang terlantar dan menderita. Gerakan menyeru untuk pemenuhan hak-hak bagi yang fakir dan terlantar inilah akhirnya memunculkan gerakan mengelolah zakat mal dan zakat fitrah. Dan dari sini pula lahirlah rumh sakit, panti asuhan yatim piatu, dan rumah orang-orang terlantar.

Mari kita lihat arti surat al-Ma'un yang membumi bagi warga Muhammadiyah:

1) Tahukah kamu orang yang mendustakan agama?, 2) itulah orang yang menghardik anak yatim, 3) dan tidak menganjurkan memberi makan orang miskin, 4) maka kecelakaanlah bagi orang-orang yang lalai dari shalatnya, 6) orang - orang yang berbuat riya', dan enggan (menolong dengan) barang berguna. 
Surat Al-Ma'un tersebut bisa disimpulkan secara umum bahwa mengandung perintah, pengabdian kepada yatim, pengabdian kepada yang miskin, tidak melalaikan shalat, tidak riya' dan tidak menolak kerjasama. Sedangkan ruh surat Al-Ma'un dalam Persyarikatan Muhammadiyah merupakan kongretisasi paham Islam Muhammadiyah, dan implementasi serta aktualisasi nialainilai Islam dalam Kehidupan.

Hasil Tanwir Muhammadiyah sebagai tentang gerakan Pencerahan, pertama Muhammadiyah sebagai gerakan Praksis berkemajuan untuk: membebaskan, memberdayakan, dan memajukan kehidupan. kedua, memberikan jawaban atas problem-problem kemanusiaan: kemiskinan, kebodohan, ketertinggalan, dan persoalan-persoalan lain yang bersifat struktural dan kultural. ketiga, menjawab masalah: kekeringan ruhani, krisis moral, kekerasan, terorisme, konflik, korupsi, kerusakan ekologis, dan bentuk-bentuk kejahatan kemanusiaan. keempat, berkomitmen untuk: mengembangkan relasi sosial yang berkeadilan tanpa dikriminasi, memuliakan martabat manusia, menjunjung tinggi nialai toleransi dan kemajemukan, membangun tatanan sosial yang utama. 


\section{Bentuk dan Model Gerakan Kemanusiaan Muhammadiyah}

Seperti yang telah dijelaskan pada sub bab di atas bahwa, Muhammadiyah sebagai gerakan sosial yang dijiwai oleh ruh Al-Ma'un dalam perjuangannya. Maka Muhammadiyah dalam gerakan pecerahan yaitu, memberi jawaban atas problem-problem kemanusiaan, seperti kemiskinan, kebodohan, ketertinggalan, dan persoalanpersoalan yang bercorak struktural dan kultural, maka model gerakan kemanusiaannya mengacu pada hal tersebut.

Menjawab masalah kemiskinan Muhammadiyah dengan Majelis Ekonominya membuat amal usaha kemitraan untuk memberikan modal bagi warga tidak mampu untuk berwirausaha dan juga pembinaan-pembinaan. Dalam hal Kebodohan Muhammadiyah menjawabnya dengan mendirikan sekolah-sekolah yang memberikan bantuan bagi masyarakat tidak mampu dengan biaya dari Lazismu (Lembaga Zakat Infaq dan Shodaqoh Muhammadiyah), sekolah yang canangkan tidak hanya mengajarkan ilmu umum tetapi juga ilmu-ilmu agama di dalamnya, sehingga manusia yang dihasilkan dari pendidikan Muhammadiyah ilmuwan diharapkan beriman dan bertaqwa (menguasai ilmu umum dan agama). Data dari Pimpinan Pusat Muhammadiyah jumlah sekolah dari tingkat PAUD 
(Pendidikan Anak Usia Dini) 4623, SD/MI 2604, SMP 1772, SMA 1143, dan Perguruan Tinggi 172. (data diambil dari https://id.wikipedia.org/wiki/Muhammadiyah).

Masalah ketertinggalan Muhammadiyah menjawabnya dengan menggagas penyaluran informasi melalui tulisan ataupun elektronik. Muhammadiyah juga melakukan kerjasama degn pihak-pihak yang memperjuangkan kemanusiaan, seperti program pemerintah tentang kesehatan, seperti penanggulangan penyakit tertentu yang menyebar di Masyarakat, Muhammadiyah tampil sebagai mitra (dengan dinas Kesehatan). Begitu pula masalah-masalah traficking (perdagangan anak dan Perempuan) serta masalah-maslah kemanusiaan Muhammadiyah dengan Aisyiyah (Perempuan Muhammadiyah) berusaha memberikan bantuan-bantuan Advokasi kepada mereka karena korban kebayakan dari masyarakat miskin.

\section{REVITALISASI GERAKAN SOSIAL MUHAMMADIYAH}

Revitalisasi menurut Haedar Nashir, memperkokoh kembali akan idealisme, misi, usaha, cita-cita, khittah, dan kepentingan gerakan Muhammadiyah. Pada peningkatan kualitas usaha melalui amal usaha, program,dan kegiatan alternatif yang bersifat unggulan di berbagai bidangnya yang 
menjadi ciri khas gerakan Muhammadiyah, seperti pemberdayaan petani, revitalisasi pendidikan, intensifikasi lembaga-lembaga kesehatan, dan sebagainya.

Maka revitalisasi gerakan sosial lebih menitik beratkan pada amal usaha Muhammadiyah pada bidang Sosial, diantaranya: Pendidikan, Kesehatan, Ekonomi dengan mengembangkan Lembaga Amil Zakat Infaq dan Sodaqoh, gerakan Kurban bersama, dll.

\section{E. RANGKUMAN}

1. Surat Al-Ma'un tersebut bisa disimpulkan secara umum bahwa mengandung perintah, pengabdian kepada yatim, pengabdian kepada yang miskin, tidak melalaikan shalat, tidak riya' dan tidak menolak kerjasama.

2. Muhammadiyah dalam gerakan pecerahan yaitu, memberi jawaban atas problem-problem kemanusiaan, seperti kemiskinan, kebodohan, ketertinggalan, dan persoalan-persoalan yang bercorak struktural dan kultural, maka model gerakan kemanusiaannya mengacu pada teologi al-ma'un.

3. Revitalisasi gerakan sosial lebih menitik beratkan pada amal usaha Muhammadiyah pada bidang Sosial, diantaranya: Pendidikan, Kesehatan, Ekonomi dengan 
mengembangkan Lembaga Amil Zakat Infaq dan Sodaqoh, gerakan Kurban bersama, dll.

\section{F. SOAL LATIHAN}

1. Surat apakah yang diajarkan oleh KH.Ahmad Dahlan? coba tulis surat tersebut beserta artinya?

2. Coba jelaskan apakah kandungan surat Al-Ma'un!

3. Mengapa Kiyai Dahlan selalu mengulang-ulang mengajarkan Surat Al-Ma'un? jelaskan!

4. apakah bentuk penerjemahan al-Ma'un yang dilakukan oleh Organisasi Muhammadiyah? jelaskan!

\section{G. DAFTAR PUSTAKA}

Munir Mulkhan, SU. Pesan dan Kisah Kai Ahmad Dahlan dalam Hikmah Muhammadiyah. Yogyakarta: Suara Muahammadiyah, 2007.

Mustthafa Kamal Pasha, Ahmad Adaby Darban. Muhammadiyah Sebagai Gerakan Islam. Yogyakarta: Citra Karsa Mandiri, 2005.

HRH. Hadjid, Pelajaran KHA Dahlan 7 Falsafah Ajaran \& 17 Kelompok Ayat Al-Qur'an. Malang: LPI PPM, 2005 
BAB. VIII

MUHAMMADIYAH SEBAGAI GERAKAN PENDIDIKAN

Nama Mata Kuliah : AIK 3 (KE-MUHAMMADIYAH-AN)

Semester : : III

SKS

: 2 sks

Pertemuan ke- $\quad: 8$

Lama Jam pertemuan $\quad: 2 \times 50$ menit

Kemampuan akhir yang diharapkan:

1. Memahami faktor yang melatarbelakangi gerakan Muhammadiyah di bidang pendidikan

2. Memahami cita pendidikan Muhammadiyah

3. Memahami bentuk dan model pendidikan Muhammadiyah

4. Memahami filsafat dan praktis gerakan pendidikan Muhammadiyah

5. Memahami tantangan dan revitalisasi gerakan pendidikan Muhammadiyah

\section{A. PENDAHULUAN}

Pada bab ini akan dipaparkan tentang faktor yang melatarbelakangi gerakan Muhammadiyah di bidang pendidikan, cita, bentuk dan model pendidikan Muhammadiyah, filsafat dan praktis gerakan pendidikan 
Muhammadiyah, serta tantangan dan revitalisasi gerakan pendidikan Muhammadiyah.

\section{B. FAKTOR YANG MELATARBELAKANGI GERAKAN MUHAMMADIYAH DI BIDANG PENDIDIKAN}

Sebagai tokoh pembaharu, Ahmad Dahlan sangat gelisah melihat sistem pendidikan yang dijalankan oleh pesantren-pesantren tradisional di Indonesia yang hanya mengutamakan hafalan. Banyak sekali pondok pesantren di Indonesia yang hanya menggunakan sistem pendidikan klasik dalam mendidik para santrinya sehingga para santri tidak mempunyai daya kritis, kurang peka terhadap realitas sosial serta tidak mampu mengantisipasi perubahan zaman yang sangat dinamis. Sebagai salah satu lembaga pendidikan, pesantren memang telah mengabdi kepada masyarakat, tetapi sistem yang dipakai kadang terlalu monolitik sehingga tidak mampu mengantisipasi perubahan zaman dan dinamika peradaban manusia.

Ahmad Dahlan merasa bahwa pesantren pada masanya belum mampu memproduksi mujtahid handal, karena hanya mempelajari ilmu-ilmu agama yang bersifat ukhrawiyah oriented seperti ilmu fiqhuddin yang meliputi ilmu bahasa arab, tafsir, hadis, tasawuf, akhlak, akidah, ilmu mantiq dan 
ilmu falak, sedangkan ilmu yang terkait dengan ilmu-ilmu keduniawian yang sering disebut dengan ilmu pengetahuan umum jarang atau bahkan mungkin tidak pernah diajarkan oleh pesantren tradisional. Padahal menurut pemahaman Ahmad Dahlan, hanya dengan menguasai ilmu-ilmu pengetahuan umum, maka manusia akan mampu mengemban misinya sebagai Khalifatullah fi al-ardli.

\section{CITA-CITA PENDIDIKAN MUHAMMADIYAH}

Menurut KH. Ahmad Dahlan, pendidikan Islam hendaknya diarahkan pada usaha membentuk manusia muslim yang berbudi pekerti luhur, alim dalam agama, luas pandangan dan paham masalah ilmu keduniaan, serta bersedia berjuang untuk kemajuan masyarakatnya. Tujuan pendidikan tersebut merupakan pembaharuan dari tujuan pendidikan yang saling bertentangan pada saat itu yaitu pendidikan pesantren dan pendidikan sekolah model Belanda. Di satu sisi pendidikan pesantren hanya bertujuan utnuk menciptakan individu yang salih dan mengalami ilmu agama. Sebaliknya, pendidikan sekolah model Belanda merupakan pendidikan sekuler yang didalamnya tidak diajarkan agma sama sekali. Akibat dualisme pendidikan tersebut lahirlah dua kutub intelegensia: lulusan pesantren yang menguasai agama tetapi tidak menguasai ilmu umum 
dan sekolah Belanda yang menguasai ilmu umum tetapi tidak menguasai ilmu agama.

Melihat ketimpangan tersebut $\mathrm{KH}$. Ahmad Dahlan berpendapat bahwa tujuan pendidikan yang sempurna adalah melahirkan individu yang utuh menguasai ilmu agama dan ilmu umum, material dan spritual serta dunia dan akhirat. Bagi KH. Ahmad Dahlan kedua hal tersebut (agamaumum, material-spritual dan dunia-akhirat) merupakan hal yang tidak bisa dipisahkan satu sama lain. Inilah yang menjadi alasan mengapa KH. Ahmad Dahlan mengajarkan pelajaran agama dan ilmu umum sekaligus di Madrasah Muhammadiyah.

Bagi Muhammadiyah, pendidikan memiliki tiga makna penting yang harus selalu dijadikan landasan dalam penyelenggaraan pendidikan Muhammadiyah. Tiga makna tersebut adalah pertama, pendidikan adalah lembaga yang merupakan perwujudan ideologi atau world view Muhammadiyah tentang ilmu, manusia ideal, dan masyarakat Islam. Muhammadiyah berpandangan bahwa ilmu adalah sesuatu yang suci karena bersumber dari Allah. Ilmu pengetahuan adalah produk pemikiran, pengamatan dan penalaran manusia atas ayat-ayat Allah yang termaktub dalam al-Qur'an dan terbentang di alam semesta. Sementara dikotomi ilmu agama dan 'kafir' adalah warisan politik yang 
tidak memiliki pijakan epistemologis, membelenggu dan memecah belah umat. ${ }^{37}$

Kedua, pendidikan adalah sarana untuk melakukan mobilitas sosial dan melakukan perubahan. Melalui pendidikan, Muhammadiyah berusaha melakukan perubahan masyarakat dengan membangun pola pikir (mindset) dan perilaku yang berdasarkan al-Qur'an. Di bidang pendidikan inilah Muhammadiyah hadir sebagai gerakan pembaharuan Islam yang terpenting dan sangat berpengaruh di awal abad keduapuluh.

Ketiga, pendidikan adalah sarana untuk membangun dan menciptakan kader-kader bagi persyarikatan, umat, dan bangsa. Pesan K.H. Ahmad Dahlan "dadiyo Kyai sing kemajuan lan ojo kesel anggonmu nyambut gawe kanggo Muhammadiyah" (Jadilah Kyai yang berkemajuan, jangan pernah letih berjuang di Muhammadiyah), menunjukkan secara tegas bahwa pendidikan adalah sarana perkaderan, karena kader adalah agent pembaharuan dan calon pemimpin.

${ }^{37}$ Abdul Mu'ti, Kurikulum Qur'ani -dalam Muhammadiyah untuk Kemanusiaan dan Peradaban, (Surabaya: Hikmah Press, 2012), 86-87 


\section{BENTUK DAN MODEL PENDIDIKAN MUHAMMADIYAH}

Berangkat dari tujuan pendidikan tersebut $\mathrm{KH}$. Ahmad Dahlan berpendapat bahwa kurikulum atau materi pendidikan hendaknya meliputi: 1) Pendidikan moral, akhlaq yaitu sebagai usaha menanamkan karakter manusia yang baik berdasarkan Al-Qur'an dan As-Sunnah. 2) Pendidikan individu, yaitu sebagai usaha untuk menumbuhkan kesadaran individu yang utuh yang berkesinambungan antara perkembangan mental dan gagasan, antara keyakinan dan intelek serta antara dunia dengan akhirat. 3) Pendidikan kemasyarakatan yaitu sebagai usaha untuk menumbuhkan kesediaan dan keinginan hidup bermasyarakat.

Di dalam menyampaikan pelajaran agama KH. Ahmad Dahlan tidak menggunakan pendekatan yang tekstual tetapi kontekstual. Karena pelajaran agama tidak cukup hanya dihafalkan atau dipahami secara kognitif, tetapi harus diamalkan sesuai situasi dan kondisi. Pertama, Cara belajarmengajar di pesantren menggunakan sistem Weton dan Sorogan, madrasah Muhammadiyah menggunakan sistem klasikal seperti sekolah Belanda.

Kedua, Bahan pelajaran di pesantren mengambil kitab-kitab agama. Sedangkan di madrasah Muhammadiyah bahan pelajarannya diambil dari buku-buku umum. Ketiga, Hubungan guru-murid. Di pesantren hubungan guru-murid 
biasanya terkesan otoriter karena para kiai memiliki otoritas ilmu yang dianggap sakral. Sedangkan madrasah Muhammadiyah mulai mengembangkan hubungan gurumurid yang akrab.

\section{E. FILSAFAT DAN PRAKTIS GERAKAN PENDIDIKAN}

\section{MUHAMMADIYAH}

\section{D.1. Landasan Filosofis Pendidikan Muhammadiyah}

\section{D.1.1. Secara ontologis}

Manusia memiliki fitrah yang senantiasa mengadakan hubungan vertikal dengan sang Khaliq (Pencipta) sebagai manifestasi dari sikap teosentris manusia yang mengakui ketuhanan Yang Maha Esa. Manusia yang diciptakan adalah manusia yang mampu mengemban tugas-tugasnya di muka bumi (hubungan horizontal), baik sebagai hamba Allah s.w.t. maupun khalifah-Nya. Untuk dapat mewujudkan fungsi kekhalifahannya, maka seseorang harus: Memiliki ilmu pengetahuan dan keterampilan, bisa melaksanakan tugas/ pekerjaan sesuai dengan ilmu dan keterampilan yang dimiliki, bisa menemukan jati dirinya sebagai apa atau siapa dirinya itu, dan Bisa bekerja sama dan berbuat sesuatu yang bermanfaat bagi orang lain.

Di sisi lain, seorang khalifah tentunya memiliki pandangan hidup yang setidak-tidaknya dapat diketahui dari jawaban- 
jawaban terhadap pertanyaan-pertanyaan berikut apa yang harus diperbuat untuk dirinya; apa yang harus diperbuat untuk alam sekitarnya; apa arti lingkungan sosial bagi dirinya dan apa yang diperbuat untuk lingkungan sosial serta apa yang harus diperbuat terhadap keturunan atau generasi penerusnya. Maka penyusunan kurikulum pendidikan Muhammadiyah adalah untuk:

1) Mengembangkan potensi peserta didik secara optimal serta interaksinya dengan tuntutan dan kebutuhan lingkungannya, tanpa mengabaikan nilai-nilai dan tradisi yang sudah mengakar di masyarakat dan masih relevan untuk dilestarikan.

2) Menumbuh-kembangkan nilai-nilai moral (akhlaq) dalam konteks perkembangan iptek dan perubahan sosial yang ada

3) Menumbuhkembangkan kreatifitas peserta didik

4) Memperkaya khazanah budaya manusia, dan Menyiapkan peserta didik untuk memiliki kecakapan hidup serta mampu dan berani menghadapi tantangan hidup sesuai dengan zamannya yang dijiwai oleh spirit Islam.

\section{D.1.2. Secara epistemologis}

Pengembangan Pendidikan Muhammadiyah harus memiliki dasar rasional tertentu, yaitu Apa kompetensi hasil 
didik? Sebagai apa? Siapa yang membutuhkan hasil didik? dan Bagaimana proses pembelajarannya agar tujuan yang diinginkan terwujud?

Agar pendidikan lebih bermakna bagi peserta didik dapat dilakukan dengan menjawab beberapa pertanyaan sebagai berikut:

1) Lulusan yang kompeten dalam hal apa yang akan dibentuk melalui program pendidikan?

2) Kemampuan dasar apa dan bagaimana yang harus ditempuh lulusan lembaga pendidikan?

3) Apa indikator-indikator atau bukti-bukti yang menunjukkan bahwa peserta didik sukses dalam mencapai kemampuan dasar dan hasil belajar yang telah ditetapkan?

4) Agar peserta didik dapat mencapai indikator-indikator tersebut di atas, maka hal-hal, masalah-masalah, latihanlatihan dan kegiatan-kegiatan apa saja yang harus dikerjakan oleh mereka dalam proses belajar dan membelajarkan?

5) Apa saja sarana dan sumber belajar, tenaga kependidikan yang seperti apa dan bagaimana, berapa biaya yang diperlukan, dan apa peran dan tanggung jawab pimpinan, unit-unit dan lain-lain untuk mencapai hasil belajar yang diinginkan? 
6) Berapa jam/ sks yang diperlukan untuk dapat mencapai hasil belajar atau mewujudkan indikator-indikator hasil belajar tersebut?

\section{D.1.3 Secara aksiologis}

Pendidikan Muhammadiyah mengarahkan peserta didik pada pengembangan kemampuan menjalankan tugas-tugas atau pekerjaan tertentu. Tugas/ pekerjaan itu bisa berbasis pada: Kebutuhan pemerintah / kebutuhan user / para pengguna jasa hasil didik, Kebutuhan pengembangan akademik atau keilmuan, Kebutuhan lembaga pendidikan itu sendiri, dan Kebutuhan peserta didik itu sendiri.

\section{F. TANTANGAN DAN REVITALISASI GERAKAN PENDIDIKAN MUHAMMADIYAH}

Pada satu abad pertama, pendidikan Muhammadiyah berhasil memposisikan dirinya sebagai kekuatan pembaharu yang mampu membaca tanda-tanda zaman sehingga mampu menghadapi gelombang kehidupan, melintasi zaman dengan rasa percaya diri dan bahkan mampu melakukan ekspansi. Memasuki abad kedua, tantangan yang dihadapi pendidikan Muhammadiyah tidak semakin ringan meskipun telah memiliki pengalaman selama satu abad. 
Seperti yang kita ketahui lembaga pendidikan yang di bawah naungan organisasi Muhammadiyah sangat lah banyak mengalami penurunan baik pada pendidik ataupun peserta didiknya. Realitas pendidikan Muhammadiyah saat ini dapat digambarkan berbentuk piramida. Di mana secara kuantitas sangat mengagumkan akan tetapi secara kualitas sebagian besar masih memprihatinkan. Yang menjadi persoalan adalah, kenapa hal ini terjadi? Apakah "ruh" purifikasi, modernisasi, dan transformasi semakin luntur di kalangan pengelola pendidikan Muhammadiyah sehingga pendidikan Muhammadiyah kurang dapat berkompetisi dengan dinamika tuntutan masyarakat dan kompetitor lainnya? Adakah yang salah dalam sistem pendidikan Muhammadiyah?

Sebagai sub sistem dari pendidikan Nasional, pendidikan Muhammadiyah menghadapi berbagai persoalan sebagaimana persoalan pendidikan nasional pada umumnya, yaitu persoalan kualitas dan relevansi. Problem pendidikan nasional saat ini yang sering dikritik dan mendapat sorotan tajam dari msyarakat adalah kecenderungan pembelajaran yang hanya menekankan pada aspek pengetahuan dan pengembangan kecerdasan intelektual peserta didik. Aspek pembentukan sikap dalam bentuk akhlak mulia dan aspek pengembangan ketrampilan yan dibutuhkan peserta didik dalam kehidupan nyata kurang atau tidak mendapat perhatian 
yang cukup. Hal ini berakibat pada pembentukan akhlak generasi muda yang memprihatinkan. ${ }^{38}$

Kondisi pendidikan dan kondisi akhlak bangsa yang demikian perlu mendapat perhatian semua pihak, terutama persyarikatan Muhammadiyah sebagai ormas Islam yang misi utamanya adalah amar ma'ruf nahi munkar. Pendidikan Muhammadiyah ditantang untuk ikut serta secara aktif mencari solusi agar pendidikan yang kita bangun membentuk perilaku generasi bangsa yang berakhlak mulia sebagaimana yang diharapkan dalam tujuan pendidikan nasional.

Selain tantangan tersebut, di Muhammadiyah khususnya, problem pendidikan yang dihadapi adalah: ${ }^{39}$

1. Problem filosofis

Kekuatan pendidikan Muhammadiyah pada hakikatnya bukan semata terletak pada kondisi yang terlihat seperti fisik, fasilitas, dan dukungan finansialnya, melainkan pada yang tidak terlihat, seperti core belief, core values, visi dan misinya. Nilai-nilai inilah yang berfungsi sebagai kekuatan moral, motivasional, dan memberi arah dan etos pengembangan.

\footnotetext{
${ }^{38}$ Maskuri, Pendidikan Muhammadiyah yang Mencerahkan Antara Cita Fakta dan Tantangan, dalam Suara Muhammadiyah Edisi no. 15, (Yogyakarta: Suara Muhammadiyah, 2015), 68.

${ }^{39}$ Tobroni, Tantangan dan Peluang Pendidikan Muhammadiyah Abad Kedua -dalam Muhammadiyah Untuk Kemanusiaan dan Peradaban (Surabaya: Hikmah Press, 2012), 105
} 
Kelemahan terbesar pendidikan Muhammadiyah terletak pada kelemahan visi dan misinya. Kelemahan visi dan misi menyebabkan tidak adanya fokus pengembangan, arah yang jelas, kekuatan dari dalam yang menggerakkan, dan nilai-nilai yang menjadi pedoman bersama.

2. Problem manajemen dan kepemimpinan

Berbagai penelitian menunjukkan, sekolah yang berkualitas biasanya dikelola dengan manajemen dan kepemimpinan yang baik. Kondisi pendidikan Muhammadiyah yang beragam mengindikasikan keragaman pola manajemen dan kepemimpinan yang beragam pula. Dalam konteks otonomi daerah dan era keterbukaan seperti sekarang ini, pendidikan Muhammadiyah perlu merespon secara cepat dan cerdas dengan menerapkan otonomi di tingkat sekolah yang berbasis manajemen (school based management) berdasarkan pada pendidikan yang berbasis pada potensi masyarakat (school based society). Manajemen dan kepemimpinan yang serba tertutup, terbatas (lingkaran orang yang itu-itu saja), enggan melakukan regenerasi, alergi terhadap orang-orang baru yang potensial, dan sikap cepat puas harus segera diakhiri.

Berdasarkan uraian sebagaimana terdapat pada pembahasan diatas bahwa berbagai inovasi dalam 
pendidikan Muhammadiyah bukanlah sesuatu hal yag mustahil tetapi harus terus dikembangkan dan diberikan apresiasi yang setingi-tingginya, selama inovasi tersebut tidak melanggar undang-undang dan peraturan-peraturan yang berlaku serta dalam rangka memperbaiki modelmodel pendidikan yang ada. Dalam pengembangannya, implementasi dari berbagai inovasi dibutuhkan kajian yang serius dan mendalam agar siapapun yang terlibat dalam pendidikan maupun masyarakat Indonesia akan memperoleh keuntungan dari inovasi tersebut.

Tanfidz Keputusan Muktamar Satu Abad (ke-47) di Yogyakarta mengamanatkan untuk mengembangkan Sistem Pendidikan Muhammadiyah yang Holistik atau menyeluruh. Majelis Pendidikan Dasar dan Menengah telah menyusun konsep Pendidikan Holistik Muhammadiyah yakni penyelenggaraan pendidikan yang mengembangkan potensi akal, hati, dan ketrampilan peserta didik yang seimbang sehingga menjadi manusia yang utuh yang memiliki keunggulan dan daya saing.

\section{RANGKUMAN}

1. Latar belakang gerakan Muhammadiyah di bidang pendidikan adalah kegelisahan Ahmad Dahlan melihat dualism praktek pendidikan antara pendidikan pesantren 
yang hanya mengajarakan ilmu agama dan pendidikan model Belanda yang hanya mengajarkan ilmu umum

2. Tujuan pendidikan Islam adalah membentuk manusia muslim yang berbudi pekerti luhur, alim dalam agama, luas pandangan dan paham masalah ilmu keduniaan, serta bersedia berjuang untuk kemajuan masyarakatnya.

3. Tiga makna pendidikan bagi Muhammadiyah adalah: pendidikan merupakan perwujudan ideologi atau world view Muhammadiyah, pendidikan adalah sarana untuk melakukan mobilitas sosial dan melakukan perubahan, dan pendidikan adalah sarana untuk membangun dan menciptakan kader-kader bagi persyarikatan, umat, dan bangsa.

4. Materi pendidikan meliputi pendidikan moral, pendidikan individu, dan pendidikan kemasyarakatan dengan menggunakan pendekatan kontekstual.

5. Model pendidikan Muhammadiyah menggunakan sistem klasikal seperti sekolah Belanda dengan menggabungkan pelajaran agama dan pelajaran umum

6. Problem yang dihadapi pendidikan Muhammadiyah adalah mencakup problem filosofis dan problem manajemen dan kepemimpinan

7. Tanfidz Keputusan Muktamar Satu Abad (ke-47) di Yogyakarta mengamanatkan untuk mengembangkan 
Sistem Pendidikan Muhammadiyah yang Holistik atau menyeluruh. yakni penyelenggaraan pendidikan yang mengembangkan potensi akal, hati, dan ketrampilan peserta didik yang seimbang sehingga menjadi manusia yang utuh yang memiliki keunggulan dan daya saing

\section{E. LATIHAN SOAL}

1. Jelaskan latar belakang gerakan Muhammadiyah di bidang pendidikan

2. Output pendidikan seperti apa yang dicita-citakan Muhammadiyah?

3. Apa makna pendidikan bagi Muhammadiyah?

4. Jelaskan model pendidikan Muhammadiyah yang membedakannya dengan dua sistem pendidikan yang ada di awal abad ke-20

5. Jelaskan tantangan yang dihadapi oleh lembaga pendidikan Muhammadiyah dan bagaimana upaya revitalisasi yang harus dilakukan? 


\section{F. REFERENSI}

Maskuri. Pendidikan Muhammadiyah yang Mencerahkan Antara Cita Fakta dan Tantangan, dalam Suara Muhammadiyah Edisi no. 15. Yogyakarta: Suara Muhammadiyah. 2015

Mu'ti, Abdul. Kurikulum Qur'ani -dalam Muhammadiyah untuk Kemanusiaan dan Peradaban, Surabaya: Hikmah Press. 2012

Tobroni, Tantangan dan Peluang Pendidikan Muhammadiyah Abad Kedua -dalam Muhammadiyah Untuk Kemanusiaan dan Peradaban. Surabaya: Hikmah Press. 2012

Najib Hamid (ed.). 2009. Satu Abad $\begin{array}{lll}\text { Muhammadiyah } \quad(1330-1430 & H) & \text { Memberi dan }\end{array}$ Mencerahkan. Surabaya: Hikmah Press

Edy Sukardi dan Suyatno (ed.). 2005. Refleksi Satu Abad Pendidikan Muhammadiyah. Jakarta: UHAMKA Press 


\section{BAB.IX}

\section{MUHAMMADIYAH DAN PEMBERDAYAAN PEREMPUAN}

Nama Mata Kuliah

Semester

SKS

Pertemuan ke-

Lama Jam pertemuan
: AIK 3 (KE-MUHAMMADIYAH-AN)

: III

: 2 sks

$: 9$

: $2 \times 50$ menit

Kemampuan akhir yang diharapkan:

1. Memahami Cara K.H. Ahmad Dahlan memberdayakan perempuan

2. Memahami Kesetaraan gender dalam Muhammadiyah

3. Memahami Peran perempuan Muhammadiyah dalam kehidupan berbangsa dan bernegara

\section{A. PENDAHULUAN}

Bab ini akan memaparkan tentang model pemikiran K.H. Ahmad Dahlan memberdayakan perempuan, kesetaraan gender dan peran perempuan Muhammadiyah dalam kehidupan Berbangsa dan bernegara. 


\section{B. CARA K.H. AHMAD DAHLAN MEMBERDAYAKAN PEREMPUAN}

Tidak dapat dipungkiri, kolonialisme Belanda yang berlangsung selama beberapa abad membawa dampak negatif yang besar pada masyarakat Indonesia, seperti munculnya rasisme dan diskriminasi. Perbedaan jenis kelamin, status sosial-ekonomi, dan etnisitas seringkali menjadi alasan diskrimasi dalam kehidupan masyarakat kolonial. Diskriminasi yang didasarkan atas perbedaan jenis kelamin, tampak melalui perbedaan kesempatan yang diberikan kepada lakilaki dan perempuan. Terutama bagi kaum perempuan, diskriminasi tidak hanya dirasakan ketika mereka masuk dalam arena publik, tetapi juga dirasakan ketika mereka diharuskan untuk berada di arena domestik. Oleh karena itulah, beberapa pejuang perempuan muncul untuk menghapuskan diskriminasi tersebut.

Namun, perjuangan perempuan yang terjadi pada abad ke sembilan belas hanya dilakukan perseorangan, bukan melalui gerakan yang terorganisir. Ini terjadi akibat belum terbentuknya jaringan pemikiran di antara para pejuang perempuan, serta masih kurang terbukanya ruang bagi perempuan untuk berinteraksi dengan masyarakat di luar lingkungan. Pejuang perempuan yang muncul pada periode itu diantaranya adalah Cut Nyak Dien, Raden Ajeng Kartini, 
Dewi Sartika, Roehana Koeddoes, dan beberapa pejuang lain. ${ }^{40}$ dari beberapa perjuangan yang dilakukan secara individu pada awalnya berupa perjuangan bersenjata atau paling tidak sebuah perjuangan pengaturan strategi. Namun, seiring perkembangan waktu, para perempuan di berbagai wilayah menyadari bahwa perjuangan yang harus mereka lakukan bukanlah perjuangan bersenjata, melainkan perjuangan melalui pendidikan.

Pada akhir abad ke sembilan belas, masyarakat Indonesia mulai berubah secara drastis, yaitu ketika kaum terpelajar dari kalangan pribumi mulai bersentuhan dengan ide nasionalisme sehingga mulailah didirikan berbagai organisasi nasionalis sebagai usaha melawan kolonialisme. ${ }^{41}$ Demikian halnya dengan organisasi perempuan yang juga mulai tumbuh untuk memberikan akses pendidikan bagi kaum perempuan.

Melihat diskriminasi yang membelenggu kaum perempuan, Ahmad Dahlan pun merasa tergerak untuk melakukan usaha-usaha mengangkat harkat dan martabat perempuan. Salah satunya adalah dengan membentuk perkumpulan perempuan yang bernama Sopo Trisno. Perkumpulan ini bergerak dalam berbagai kegiatan

${ }^{40}$ A. Adaby Darban (et. al.) (ed.), Aisyiyah dan Sejarah Pergerakan Perempuan Indonesia: Sebuah Tinjauan Awal, (Yogyakarta: Jurusan Sejarah FIB UGM, 2010), 20

${ }^{41}$ Ibid., 41 
pendidikan bagi perempuan dan kegiatan bidang sosial seperti menyantuni anak yatim piatu. Pada 22 April 1917, atas usulan KH Muchtar, maka perkumpulan Sopo Trisno ini kemudian diubah namanya menjadi Aisyiyah dan menjadi bagian dari Muhammadiyah. ${ }^{42}$

Berdirinya Aisyiyah, juga didasari tujuan kaderisasi yang hendak dilakukan Ahmad Dahlan demi menjamin keberlangsungan gerak langkah Muhammadiyah. Usahanya untuk mencari bibit-bibit baru yang dapat mewarisi ideidenya, dan mengembangkan organisasi yang telah ia dirikan ditempuh melalui pendidikan dan pengajian-pengajian. Sebelum muhammadiyah resmi didirikan, Ahmad Dahlan lebih dahulu mendirikan sekolah rakyat yang murid-muridnya terdiri dari laki-laki dan perempuan. Setelah Muhammadiyah berdiri, ia mendirikan juga Standard School di Suronatan, sedang sekolah rakyat di Kauman dikhususkan untuk perempuan, sampai sekarang terkenal dengan Pawiyatan Wanita Muhammadiyah Kauman. Di antara murid-murid perempuan yang termasuk kelompok para kader yang dibina

Slamet Abdullah dan M. Muslich KS, Seabad Muhammadiyah dalam Pergumulan Budaya Nusantara, (Yogyakarta: Global Pustaka Utama, 2010), 173 
Ahmad Dahlan adalah Aisyah Hilal, Busro Isom, Zahroh Muchsin, Wadiah Nuh, Dalalah Hisyam, dan Badilah Zuber. ${ }^{43}$

\section{KESETARAAN GENDER DALAM MUHAMMADIYAH}

Ketika kaum perempuan di Indonesia diposisikan secara marjinal dan diskriminatif, sebagaimana lama didengungkan oleh R.A. Kartini, Rasuna Said, Cut Nyak Dien, dan pejuang perempuan Indonesia lainnya, Muhammadiyah bangun dan menerobos kebekuan tersebut dengan memelopori berdirinya gerakan perempuan muslim, yakni Aisyiyah. Perempuan didorong untuk mengecap pendidikan, melakukan mobilitas sosial secara leluasa, menjadi da'iyah atau muballighat, menjadi pendidik, menjalani profesi, dan memenuhi hak-hak dasarnya sebagaimana yang dimiliki laki-laki.

Kelahiran Aisyiyah menjadi sangat penting dan berarti dalam pergerakan Islam modern di Indonesia. Kehadiran Aisyiyah merupakan inspirasi terpenting dari pesan Islam sebagai agama yang memuliakan harkat dan martabat perempuan tanpa diskriminasi. ${ }^{44}$ Tanpa harus merujuk pada gerakan emansipasi Barat, Muhammadiyah telah membuka jalan baru

${ }^{43}$ Achmad Jainuri, Muhammadiyah Gerakan Reformasi Islam di Jawa Pada Awal Abad XX, (Sidoarjo, Umsida Press, 2011), 43

${ }^{44}$ Haedar Nashir, Muhammadiyah Abad Kedua, (Yogyakarta: Suara Muhammadiyah, 2011), 58 
gerakan kemajuan kaum perempuan ketika golongan Islam lain belum masuk ke area baru tersebut.

Sejak awal berdirinya, Muhammadiyah telah memberi ruang yang cukup "maju" bagiperempuan untuk berkiprah di ruang publik. KH. Ahmad Dahlan nampaknya sadar betul akanpentingnya memajukan kaum perempuan, sebelum akhirnya mendirikan Aisyiyah. Sebagaiawal langkahnya beliau merekrut enam "Siti" sebagai kader inti yang akan dijadikan pimpinan Aisyiyah kelak. Keenam perempuan tersebut adalah Siti Barijah, Siti Dawimah, SitiDalalah, Siti Busjro, Siti Wadingah dan Siti Badilah. Dalam perjalanannya, keenam "Siti"inilah menjadi pimpinan inti Aisyiyah yang pertama dengan Siti Barijah dan Siti Badilahsebagai ketua dan sekretaris. (Alfian, 1989 : 172).

Pemberian kesempatan bagi perempuan untuk berkiprah di ruang publik tidak hanya dilakukan oleh KH Ahmad Dahlan saja. Setelah era kemerdekaan, bukti dukungan Muhammadiyah untuk gerakan kesetaraan gender pun juga semakin besar. Keluarnya buku hasil kerjasama dengan komnas perempuan berjudul "Memecah Kebisuan: Agama Mendengar Suara Perempuan Korban Kekerasan Demi Keadilan (Respon Muhammadiyah)" adalah menjadi salah satu 
bukti kontribusi Muhammadiyah dalam mewujudkan keadilan gender. $^{45}$

Dalam perkembangannya, Muhammadiyah juga memberi ruang yang membahas persoalan perempuan sebagai landasan normatif dan teologisnya sebagaimana terdapat dalam: Himpunan Putusan Tarjih (HPT), Adabul Mar'ah fil Islam, Anggaran Dasar dan Anggaran Rumah Tangga (AD/ART) Muhammadiyah dan dalam Pernyataan Pikiran Muhammadiyah Abad Kedua. Teks-teks hadits yang dilematis dan misoginis seperti larangan bepergian tanpa didampingi mahrom, larangan menjadi hakim dan hadits-hadits misoginis yang lain telah dikontekstualisasikan dengan situasi zaman yang ada sehingga kaum perempuan tak ada hambatan lagi untuk berakivitas lebih luas baik secara sosial maupun kultural. $^{46}$

\section{PERAN PEREMPUAN MUHAMMADIYAH DALAM KEHIDUPAN BERBANGSA DAN BERNEGARA}

Muhammadiyah melalui gerakan Aisyiyah sejak tahun 1917 telah berkiprah dalam pemberdayaan perempuan sekaligus melakukan pembaruan Islam dengan menjadikan perempuan sebagaimana halnya laki-laki memiliki martabat dan peran

${ }^{45}$ A. Adaby Darban (et. al.) (ed.), op. cit., 239

${ }^{46}$ Tafsir, Pandangan Muhammadiyah Tentang Perempuan, http://tarjih.muhammadiyah.or.id, 7 Oktober 2017 
yang sama-sama mulianya dalam kehidupan. Aisyiyah sebagai organisasi otonom Muhammadiyah dan gerakan perempuan Indonesia tertua, memiliki peran sentral dalam Kongres Wanita I tahun 1928 yang sangat bersejarah. Sebelas tahun sebelum itu, Aisyiyah bahkan telah melakukan kepeloporan dan peran historis yang monumental dalam memprakarsai kebangunan perempuan Islam pada khususnya dan perempuan Indonesia pada umumnya. Aisyiyah bersama Muhammadiyah dengan misi dakwah Islam yang diyakininya, melakukan gerakan melawan kolonialisme, diskriminasi pendidikan, membebaskan rakyat dari kebodohan dan kejumudan, serta membangun kehidupan baru yang makmur dan bermartabat. ${ }^{47}$

Selama satu abad usianya, Aisyiyah telah menyumbangkan perannya yang tidak dapat disepelekan pada bangsa Indonesia. Dalam bidang agama, Aisyiyah melakukan dakwah tidak saja untuk kalangan santri, namun juga untuk kalangan abangan dengan materi yang disesuaikan baik melalui pengajian maupun tulisan sejak diterbitkannya Suara Aisyiyah pada tahun 1922. Sesudah kemerdekaan, dakwah juga dilakukan melalui media elektronik. Aisyiyah juga mempelopori berdirinya Mushalla untuk perempuan, yang

${ }^{47}$ Haedar Nashir, Muhammadiyah Abad Kedua, (Yogyakarta: Suara Muhammadiyah, 2011), 95 
pertama kali berdiri di Kauman Yogyakarta pada tahun 1922, kemudian diikuti oleh beberapa cabang Aisyiyah. Usaha ini merupakan suatu kemajuan karena perempuan mempunyai tempat ibadah sendiri yang berfungsi pula sebagai tempat pengajian atau membicarakan masalah agama dan kemajuan perempuan. Sampai tahun 1971, jumlah mushalla Aisyiyah tercatat sebanyak 152 di seluruh Indonesia. ${ }^{48}$

Sementara itu kegiatan Aisyiyah dalam bidang sosial telah dilakukan sebelum Aisyiyah resmi didirikan pada 1917 yaitu dalam bentuk penyantunan anak yatim. Hingga tahun 1974, terdapat 27 panti asuhan yatim piatu Aisyiyah yang tersebar di seluruh Indonesia. Selain itu, Aisyiyah juga melahirkan program Asuhan Keluarga yang menggunakan keluarga dan rumah tangga sebagai tempat penampungan anak asuh. Sistem asuhan keluarga seperti ini lebih memungkinkan dibentuknya keluarga tiruan sehingga anak akan memperoleh asuhan yang lebih baik serta merasakan perhatian dari keluarga yang mengasuhnya.

Masalah kesehatan menjadi perhatian yang penting dari Aisyiyah terutama kesehatan ibu dan anak. Untuk itu Aisyiyah mendirikan Balai Kesejahteraan Ibu dan Anak serta Rumah Bersalin. Besarnya perhatian Aisyiyah terhadap kesehatan

${ }^{48}$ A. Adaby Darban (et. al.) (ed.), Aisyiyah dan Sejarah Pergerakan Perempuan Indonesia: Sebuah Tinjauan Awal, (Yogyakarta: Jurusan Sejarah FIB UGM, 2010), 140 
secara umum juga disampaikan melalui tulisan-tulisan di majalah Suara Aisyiyah. Peranan Aisyiyah dalam bidang kesehatan cukup maju karena didukung oleh sumber daya manusia di bidang kesehatan seperti dokter dan paramedis yang dimiliki Aisyiyah.

Dalam bidang pendidikan, pemberantasan buta huruf, khususnya bagi perempuan, merupakan kegiatan yang diprioritaskan. Pemberantasan buta huruf menjadi salah satu keputusan kongres KOWANI pada tahun 1949 selain penyelenggaraan kursus tentang pengetahuan umum, kenegaraan, dan kemasyarakatan. Namun di lingkungan Aisyiyah, program-program tersebut telah dilaksanakan dalam bentuk kursus-kursus sejak tahun 1923. Pemberantasan buta huruf tidak hanya dilakukan di selurh pulau Jawa saja, tetapi juga di luar pulau Jawa. Usaha ini sampai tahun 1960-an pernah menjadi gerakan yang diselenggarakan secara nasional oleh Aisyiyah. Selain pemberantasan buta huruf, Aisyiyah juga menangani pendidikan anak usia dini yang embrionya sudah ada sejak tahun 1919 yang didirikan oleh remaja putri yang kemudian tergabung dalam Nasyiatul Aisyiyah, kemudian diserahkan kepada Aisyiyah pada tahun 1926. Selain itu, Aisyiyah juga mendirikan Sekolah Kesejahteraan Keluarga Pertama, Sekolah Kesejahteraan Keluarga Atas, Sekolah Pendidikan Guru, dan Sekolah Bidan. 
Peranan Aisyiyah dalam bidang pendidikan memberi dampak positif pada kemajuan pendidikan perempuan. Kesadaran akan pentingnya pendidikan modern sejak awal berdirinya telah melahirkan intelektual muslim perempuan yang berkualitas. Tampilnya intelektual perempuan ini memegang peranan strategis dalam dua sisi, yaitu bagi kepentingan pengembangan internal Aisyiyah, dan bagi perkembangan pendidikan perempuan Indonesia.

Selain peran-peran Aisyiyah dalam beberapa bidang yang telah dibahas sebelumnya, Aisyiyah juga memiliki peran yang penting dalam bidang ekonomi. Pada Muktamar Muhammadiyah tahun 1982, salah satu keputusannya adalah mewujudkan cita-cita membentuk Keluarga Sakinah. Di antara strategi yang ditempuh Aisyiyah adalah meningkatkan ekonomi keluarga melalui peningkatan ketrampilan wirausaha, dan koperasi. ${ }^{49}$

Dalam Program Kerja Majelis Ekonomi dan Ketenagakerjaan juga disebutkan bahwa Aiyiyah mengarahkan gerakannya untuk membangun kesadaran dan perilaku ekonomi untuk meningkatkan taraf hidup dan kesejahteraan warga, umat, dan masyarakat, antara lain dengan optimalisasi pendampingan dan pembinaan ekonomi melalui program Bina Usaha Ekonomi Keluarga (BUEKA) di komunitas,

${ }^{49}$ Ibid., 173 
mengembangkan usaha-usaha dalam meningkatkan ketrampilan kelompok masyarakat khususnya kelompok miskin, dan menguatkan posisi serta kondisi usaha mikro kecil yang dikelola perempuan dalam hal akses dan kontrol terhadap sumber daya ekonomi. ${ }^{50}$

\section{E. RANGKUMAN}

1. Melihat diskriminasi yang membelenggu kaum perempuan, Ahmad Dahlan merasa tergerak untuk melakukan usahausaha mengangkat harkat dan martabat perempuan dengan membentuk perkumpulan perempuan yang bernama Sopo Trisno. Perkumpulan ini bergerak dalam berbagai kegiatan pendidikan bagi perempuan dan kegiatan bidang sosial seperti menyantuni anak yatim piatu. Pada 22 April 1917, atas usulan KH Muchtar, maka perkumpulan Sopo Trisno ini kemudian diubah namanya menjadi Aisyiyah dan menjadi bagian dari Muhammadiyah.

2. Dengan didirikannya Aisyiyah menunjukkan bahwa Muhammadiyah telah membuka jalan baru gerakan kemajuan bagi kaum perempuan ketika golongan Islam lain belum melakukannya. Menurut Muhammadiyah, Islam yang berkemajuan adalah Islam yang menyemaikan benih-benih

\footnotetext{
${ }^{50}$ http://www.aisyiyah.or.id/id/page/majelis-ekonomi-danketenagakerjaan.html 9 Oktober 2017
} 
kebenaran, kebaikan, kedamaian, keadilan, kemaslahatan, kemakmuran dan keutamaan hidup secara dinamis bagi seluruh umat manusia serta menjunjung tinggi kemuliaan manusia baik laki-laki maupun perempuan tanpa diskriminasi

3. Selama satu abad usianya, Aisyiyah telah banyak berperan bagi kemajuan dan kesejahteraan bangsa Indonesia melalui kerja nyatanya di berbagai bidang dakwah, pendidikan, kesejahteraan sosial, politik, dan ekonomi.

F. LATIHAN SOAL

1. Bagaimana cara KH Ahmad Dahlan memberdayakan perempuan? Jelaskan latar belakang beliau melakukan hal tersebut

2. Jelaskan bagaimana dukungan Muhammadiyah terhadap kesetaraan gender

3. Bagaimana peran Aisyiyah terhadap kemajuan dan kesejahteraan bangsa dan negara Indonesia.

G. REFERENSI

Darban, A. Adaby (et. al.) (ed.). Aisyiyah dan Sejarah Pergerakan Perempuan Indonesia: Sebuah Tinjauan Awal. Yogyakarta: Jurusan Sejarah FIB UGM. 2010 
Abdullah, Slamet dan M. Muslich KS. Seabad Muhammadiyah dalam Pergumulan Budaya Nusantara. Yogyakarta: Global Pustaka Utama. 2010

Jainuri, Achmad. Muhammadiyah Gerakan Reformasi Islam di Jawa Pada Awal Abad XX. Sidoarjo: Umsida Press. 2011

Nashir, Haedar. Muhammadiyah Abad Kedua.

Yogyakarta: Suara Muhammadiyah. 2011

Tafsir. Pandangan Muhammadiyah Tentang

Perempuan. http://tariih.muhammadiyah.or.id, 7 Oktober 2017

Program Majelis Ekonomi dan Ketenagakerjaan. http://www.aisyivah.or.id, 9 Oktober 2017 
BAB. $X$

MUHAMMADIYAH SEBAGAI GERAKAN EKONOMI

Nama Mata Kuliah

: AIK 3 (KE-MUHAMMADIYAH-AN)

Semester

: III

SKS

: 2 sks

Pertemuan ke-

$: 10$

Lama Jam pertemuan

: $2 \times 50$ menit

Kemampuan akhir yang diharapkan:

1. Memahami prinsip ekonomi Muhammadiyah

2. Memahami pasang surut gerakan ekonomi Muhammadiyah

3. Memahami bentuk dan model gerakan ekonomi Muhammadiyah

\section{A. PENDAHULUAN}

Pada bab ini akan dipaparkan prinsip ekonomi Muhammadiyah, pasang surut gerakan ekonomi dan bentuk serta model gerakan ekonomi Muhammadiyah.

\section{B. PRINSIP EKONOMI MUHAMMADIYAH}

Muhammadiyah adalah gerakan yang berlandaskan Islam, sehingga dalam setiap aktivitasnya selalu menempatkan nilainilai Islam sebagai nilai utama yang dijunjung tinggi. Tidak 
terkecuali dalam melaksanakan gerakan ekonominya, Muhammadiyah berpegang pada prinsip ekonomi Islam. Prinsip-prinsip tersebut adalah: ${ }^{51}$

a. Tugas manusia di muka bumi adalah memakmurkan bumi, maka seluruh upaya yang dilakukan manusia harus memperhatikan kemakmuran seluruh penduduk bumi. ${ }^{52}$

b. Bekerja mencari nafkah merupakan bagian dari ibadah kepada Allah SWT. ${ }^{53}$

c. Melakukan aktivitas perekonomian secara halal dan menghindari cara yang haram dan bathil serta syubhat. ${ }^{54}$ Oleh sebab itu, setiap muslim diharamkan mencari nafkah dengan cara mencuri, korupsi, suap menyuap, curang, dan sebagainya.

d. Memperhatikan prinsip keseimbangan, antara bekerja dan beribadah, $^{55}$ antara keuntungan pribadi dan kemaslahatan masyarakat dan lingkungan. Hal ini sesuai dengan Pedoman Hidup Islami warga Muhammadiyah yang menyebutkan bahwa dalam kegiatan bisnis ekonomi

${ }^{51}$ Majelis Ekonomi PP Muhammadiyah, Program Pemberdayaan Ekonomi Rakyat, (Jakarta: Majelis Ekonomi PP Muhammadiyah, 2003), 24-32

${ }^{52}$ Q.S. Hud,11: 61

${ }^{53}$ Q.S. Al-Jumu'ah, 62: 10; Q.S. Al-Mulk, 67: 15

${ }^{54}$ Q.S. an-Nisa', 4: 29; Q.S. al-Baqarah, 2: 188

${ }^{55}$ Q.S. al-Qashash, 28: 77 
pada dasarnya semua bentuk kerja diperbolehkan sepanjang tidak merugikan kemaslahatan manusia. ${ }^{56}$

e. Segala harta dan hasil yang diperoleh hanyalah titipan Allah, oleh karenanya harus dibelanjakan di jalan Allah. Setiap muslim harus percaya bahwa dirinya adalah makhluk Allah dan bekerja dengan kekuatan dari Allah dan melalui sarana dari Allah sehingga harta yang diperoleh adalah harta Allah yang dititipkan padanya.

f. Meninggalkan riba dalam segala bentuk, sebaliknya dibolehkan jual beli dengan tingkat keuntungan yang wajar $^{57}$

g. Menjaga profesionalitas dalam bekerja ${ }^{58}$

\section{PASANG SURUT GERAKAN EKONOMI MUHAMMADIYAH}

Muhammadiyah lahir dari gagasan tokoh berlatar belakang saudagar. Oleh karena itu pada awal sejarahnya, Muhammadiyah tidak bisa dipisahkan dari gerakan ekonomi. Muhammadiyah dan bisnis pada periode awal merupakan dua kalimat yang diucapkan dalam satu nafas. Perkembangan organisasi di berbagai kota di luar Yogyakarta tidak terlepas

\footnotetext{
${ }^{56}$ Asymuni Abdurrahman, dkk., Pedoman Hidup Islami Warga Muhammadiyah, (Yogyakarta: Suara Muhammadiyah, 2009), 80 ${ }^{57}$ Q.S. al-Baqarah, 2: 275

${ }^{58}$ H.R. Baihaqi yang artinya "Sesungguhnya Allah menyukai seseorang dari kamu yang bila bekerja, ia menekuni pekerjaannya."
} 
dari peran para tokoh pada zamannya yang memadukan dua kepentingan sekaligus, yaitu bisnis dan dakwah. Muhammadiyah dapat menembus Jawa Timur pada dekade kedua, tidak lain karena aktivitas bisnis Ahmad Dahlan yang menggunakan jaringan pedagang batik. Muhammadiyah lebih dikenal sebagai organisasi perkotaan karena penyebarannya melalui pusat-pusat perdagangan.

Dalam perkembangan di kemudian hari ternyata dunia bisnis cenderung ditinggalkan, untuk lebih fokus pada gerakan dakwah. Dakwah dan bisnis tidak lagi menjadi aktivitas yang melekat secara personal. Gerakan, program, dan institusi ekonomi lalu digerakkan di luar gerakan dakwah. Para penggerak organisasi pun kemudian mengalami perubahan peran. Semula pelaku bisnis, lalu berubah menjadi pengurus kegiatan ekonomi yang dimiliki Muhammadiyah. Dalam perkembangan berikutnya ketika dunia bisnis menghadapi situasi sulit, maka banyak yang kemudian memilih jadi pegawai. Pada saat inilah Muhammadiyah perlahan namun pasti mulai keluar dari fitrahnya.

Kalaupun ada sektor ekonomi yang dikelola, perkembangannya tidak terlalu menggembirakan. Bahkan kasus Bank Persyarikatan Indonesia (BPI) yang menjadi salah satu ikon enterpreuner Muhammadiyah dalam sektor ekonomi mengalami gagal total yang pada akhirnya tutup 
total dan menggandeng pihak professional lain untuk mengelolanya. Bahkan hampir seluruh energy Muhammadiyah dalam masa kepemimpinan Ahmad Syafi'i Maarif terkuras untuk menyelesaikan persoalan-persoalan yang berkaitan dengan amal usaha Muhammadiyah yang satu ini.

Demikian halnya dengan lembaga ekonomi Muhammadiyah pada level mikro, seperti Koperasi Muhammadiyah, BMT Muhammadiyah yang dinilai masih berjalan di tempat bahkan sebagiannya ada yang tutup. Wajar kemudian jika Presiden Susilo Bambang Yudhoyono dalam pembukaan sidang Tanwir Muhammadiyah di Yogyakarta mengkritik gerakan ekonomi Muhammadiyah yang dinilai belum mampu berbuat banyak dan memberikan output yang menggembirakan. Presiden menilai bahwa Muhammadiyah masih sangat lemah dalam aspek gerakan ekonomi. ${ }^{59}$

\section{BENTUK DAN MODEL GERAKAN EKONOMI}

\section{MUHAMMADIYAH}

Salah satu tantangan sekaligus peluang dakwah Muhammadiyah memasuki seratus tahun kedua adalah restrukturisasi ideologi ekonomi, terutama dalam

\footnotetext{
${ }^{59}$ Deni al Asy'ari, Selamatkan Muhammadiyah, (Yogyakarta: Kibar
} Press, 2009), 121-122 
mensistemasikan kembali etika profetik dalam bermuamalah. Hal ini menjadi sangat penting di tengah kegalauan masyarakat dunia terhadap dominasi kapitalisme yang telah melahirkan ketimpangan sosial dan dekadensi hampir di semua bidang. Oleh karena itu Muhammadiyah harus ambil bagian dalam mengubah hukum-hukum pasar yag ada dengan menekankan nilai etika yang lebih tinggi, seperti disiplin diri, kejujuran, keadilan, moderasi, spirit publik, dan penghormatan kepada martabat manusia, sebelum bersaing di pasar. ${ }^{60}$

Berdasarkan Keputusan Muktamar Muhammadiyah ke-44 tahun 2000 di Jakarta ditetapkan program kerja di bidang ekonomi sebagai berikut :

1. Mewujudkan sistem Jam'iah (Jaringan Ekonomi Muhammadiyah) sebagai revitalisasi gerakan dakwah secara menyeluruh.

2. Mengembangkan pemikiran-pemikiran dan konsepkonsep pengembangan ekonomi yang beroreantasi kerakyatan dan keislaman, seperti etos kerja, etos kewiraswastaan, etika bisnis, etika manajemen, masalahmasalah monopoli-eligopoli-kartel, keuangan dan permodalan, teori ekonomi islam, etika profesi, dan lain-

\footnotetext{
${ }^{60}$ Fakhrurazi Reno Sutan, Muhammadiyah Dan Bisnis, http://www.umj.ac.id/main/artikel/index.php?detail=20090301205320 5 september 2017, 3:29 pm
} 
lain sesuai dengan kebutuhan dan perkembangan aktual yang terjadi dalam dunia ekonomi.

3. Melancarkan program pemberdayaan ekonomi rakyat meliputi pengembangan sumber daya manusia dalam aspek ekonomi, pembentukan dan pengembangan lembaga keungan masyarakat, pengembangan Bank Syariah, pengembangan kewiraswastaan dan usaha kecil, pengembangan koperasi dan pengembangan badan usaha milik Muhammadiyah (BUMM) yang benar-benar kongrit dan produktif.

4. Intensifikasi pusat data ekonomi dan pengusaha Muhammadiyah yang dapat mendukung pengembangan program-program ekonomi.

5. Menggalang kerjasama dengan berbagai pihak untuk mengembangkan program-program ekonomi dan kewiraswastaan di lingkungan Muhammadiyah.

6. Mengembangkan pelatihan-pelatihan dan pilot proyek pengembangan ekonomi kecil dan menengah baik secara sendiri maupun kerjasama dengan lembaga-lembaga luar sesuai dengan perencanaan program ekonomi dan kewiraswastaan Muhammadiyah.

7. Mengkoordinasikan seluruh kegiatan ekonomi bisnis dan kewiraswastaan di bawah Majelis Ekonomi dan 
memberlakukan Majelis Ekonomi sebagai satu-satunya yang memutuskan kebijakan di bidang ekonomi

Untuk melaksanakan program tersebut, Muhammadiyah mencanangkan beberapa program aksi seperti menumbuhkan Jamaah Swadaya Muhammadiyah, membentuk Baitut Tamwil Muhammadiyah, serta menumbuhkan usaha-usaha unggulan jamaah.

Peran ekonomi Muhammadiyah sangat luas, baik dalam memajukan ekonomi termasuk di dalamnya kualitas teknologi dan kualitas produksi maupun dalam hal pemerataan, dan pembebasan dari kelaparan dan kemiskinan. Di samping itu, pengendalian pengendalian pertumbuhan dan kemajuan industry, perilaku SDM dalam mengejar kinerja tetap harus dibimbing dengan mengajarkan keimanan, kesalihan, serta silaturrahim. Dengan demikian tujuan yang lebih mulia dari ekonomi yaitu keberadaban manusia, fungsi sosial dan kemanusiaan merupakan misi tertinggi. Hal inilah yang membedakan ekonomi Muhammadiyah dengan ekonomi konvensional yang hanya mengejar kemakmuran. 
E. RANGKUMAN

1. Dalam melaksanakan gerakan ekonominya, Muhammadiyah berpegang pada prinsip ekonomi Islam

2. Pada awal sejarahnya, Muhammadiyah tidak bisa dipisahkan dari gerakan ekonomi. Perkembangan organisasi di berbagai kota di luar Yogyakarta tidak terlepas dari peran para tokoh pada zamannya yang memadukan dua kepentingan sekaligus, yaitu bisnis dan dakwah. Muhammadiyah lebih dikenal sebagai organisasi perkotaan karena penyebarannya melalui pusat-pusat perdagangan.

3. Dalam perkembangannya, gerakan ekonomi Muhammadiyah dinilai belum mampu berbuat banyak dan memberikan output yang menggembirakan.

4. Salah satu tantangan sekaligus peluang dakwah Muhammadiyah memasuki seratus tahun kedua adalah restrukturisasi ideologi ekonomi untuk melawan dominasi kapitalisme.

F. LATIHAN SOAL

1. Prinsip-prinsip apa saja yang dipegang Muhammadiyah dalam bidang ekonomi?

2. Jelaskan mengenai kondisi pasang surut gerakan ekonomi Muhammadiyah 
3. Mengapa Muhammadiyah dikenal sebagai organisasi 'perkotaan'?

G. REFERENSI

Abdurrahman,Asymuni dkk. Pedoman Hidup Islami Warga Muhammadiyah. Yogyakarta: Suara Muhammadiyah. 2009

Majelis Ekonomi PP Muhammadiyah, Program Pemberdayaan Ekonomi Rakyat. Jakarta: Majelis Ekonomi PP Muhammadiyah. 2003

al Asy'ari, Deni.Selamatkan Muhammadiyah. Yogyakarta: Kibar Press, 2009.

Sutan,Fakhrurazi Reno.Muhammadiyah Dan Bisnis.

http://www.umj.ac.id/main/artikel/index.php?detail=200 $\underline{90301205320} 5$ september 2017, 3:29 pm 


\section{BAB XI}

\section{PERAN KEBANGSAAN MUHAMMADIYAH DI INDONESIA}

Nama Mata Kuliah

Semester

SKS

Pertemuan ke-

Lama Jam pertemuan
: AIK 3 (KE-MUHAMMADIYAH-AN)

: III

: 2 sks

: 1 (satu)

: $2 \times 50$ menit

Kemampuan akhir yang diharapkan:

1. Memahami khittah Muhammadiyah dalam kehidupan berbangsa dan bernegara

2. Memahami Muhammadiyah sebagai pendiri NKRI

3. Memahami tanggungjawab Muhammadiyah terhadap NKRI

4. Memahami bentuk dan model peran kebangsaan Muhammadiyah

\section{A. PENDAHULUAN}

pada bab ini akan dipaparkan tentang Khittah Muhammadiyah dalam kehidupan berbangsa dan bernegara, keterlibatan Muhammadiyah terhadap pendirian Muhammadiyah, serta peran kebangsaan Muhammadiyah. 


\section{B. KHITTAH MUHAMMADIYAH DALAM KEHIDUPAN BERBANGSA DAN BERNEGARA (KHITTAH DENPASAR TAHUN 2002)}

Muhammadiyah adalah Gerakan Islam yang melaksanakan da'wah amar ma'ruf nahi munkar dengan maksud dan tujuan menegakkan dan menjunjung tinggi Agama Islam sehingga terwujud masyarakat Islam yang sebenarbenarnya. Muhammadiyah berpandangan bahwa Agama Islam menyangkut seluruh aspek kehidupan meliputi aqidah, ibadah, akhlaq, dan mu'amalat dunyawiyah yang merupakan satu kesatuan yang utuh dan harus dilaksanakan dalam kehidupan perseorangan maupun kolektif. Dengan mengemban misi gerakan tersebut Muhammadiyah dapat mewujudkan atau mengaktualisasikan Agama Islam menjadi rahmatan lil-'alamin dalam kehidupan di muka bumi ini.

Muhammadiyah berpandangan bahwa berkiprah dalam kehidupan bangsa dan negara merupakan salah satu perwujudan dari misi dan fungsi melaksanakan da'wah amar ma'ruf nahi munkar sebagaimana telah menjadi panggilan sejarahnya sejak zaman pergerakan hingga masa awal dan setelah kemerdekaan Indonesia. Peran dalam kehidupan bangsa dan negara tersebut diwujudkan dalam langkahlangkah strategis dan taktis sesuai kepribadian, keyakinan dan cita-cita hidup, serta khittah perjuangannya sebagai acuan 
gerakan sebagai wujud komitmen dan tanggungjawab dalam mewujudkan "Baldatun Thoyyibatun Wa Rabbun Ghafur".

Bahwa peran dalam kehidupan berbangsa dan bernegara dapat dilakukan melalui dua strategi dan lapangan perjuangan. Pertama, melalui kegiatan-kegiatan politik yang berorientasi pada perjuangan kekuasaan/kenegaraan (real politics, politik praktis) sebagaimana dilakukan oleh partaipartai politik atau kekuatan-kekuatan politik formal di tingkat kelembagaan negara. Kedua, melalui kegiatan-kegiatan kemasyarakatan yang bersifat pembinaan atau pemberdayaan masyarakat maupun kegiatan-kegiatan politik tidak langsung (high politics) yang bersifat mempengaruhi kebijakan negara dengan perjuangan moral (moral force) untuk mewujudkan kehidupan yang lebih baik di tingkat masyarakat dan negara sebagaimana dilakukan oleh kelompok-kelompok kepentingan (interest groups).

Muhammadiyah secara khusus mengambil peran dalam lapangan kemasyarakatan dengan pandangan bahwa aspek kemasyarakatan yang mengarah kepada pemberdayaan masyarakat tidak kalah penting dan strategis daripada aspek perjuangan politik kekuasaan. Perjuangan di lapangan kemasyarakatan diarahkan untuk terbentuknya masyarakat utama atau masyarakat madani (civil society) sebagai pilar utama terbentuknya negara yang berkedaulatan rakyat. Peran 
kemasyarakatan tersebut dilakukan oleh organisasi-organisasi kemasyarakatan seperti halnya Muhammadiyah. Sedangkan perjuangan untuk meraih kekuasaaan (power struggle) ditujukan untuk membentuk pemerintahan dalam mewujudkan tujuan negara, yang peranannya secara formal dan langsung dilakukan oleh partai politik dan institusi-institusi politik negara melalui sistem politik yang berlaku. Kedua peranan tersebut dapat dijalankan secara objektif dan saling terkait melalui bekerjanya sistem politik yang sehat oleh seluruh kekuatan nasional menuju terwujudnya tujuan negara.

Muhammadiyah sebagai organisasi sosial-keagamaan (organisasi kemasyarakatan) yang mengemban misi da'wah amar ma'ruf nahi munkar senantiasa bersikap aktif dan konstruktif dalam usaha-usaha pembangunan dan reformasi nasional sesuai dengan khittah (garis) perjuangannya serta tidak akan tinggal diam dalam menghadapi kondisi-kondisi kritis yang dialami oleh bangsa dan negara. Karena itu, Muhammadiyah senantiasa terpanggil untuk berkiprah dalam kehidupan berbangsa dan bernegara dengan berdasarkan pada khittah perjuangan sebagai berikut:

Muhammadiyah meyakini bahwa politik dalam kehidupan bangsa dan negara merupakan salah satu aspek dari ajaran Islam dalam urusan keduniawian (al-umur addunyawiyat) yang harus selalu dimotivasi, dijiwai, dan dibingkai 
oleh nilai-nilai luhur agama dan moral yang utama. Karena itu diperlukan sikap dan moral yang positif dari seluruh warga Muhammadiyah dalam menjalani kehidupan politik untuk tegaknya kehidupan berbangsa dan bernegara.

Muhammadiyah meyakini bahwa negara dan usahausaha membangun kehidupan berbangsa dan bernegara, baik melalui perjuangan politik maupun melalui pengembangan masyarakat, pada dasarnya merupakan wahana yang mutlak diperlukan untuk membangun kehidupan di mana nilai-nilai Ilahiah melandasi dan tumbuh subur bersamaan dengan tegaknya nilai-nilai kemanusiaan, keadilan, perdamaian, ketertiban, kebersamaan, dan keadaban untuk terwujudnya "Baldatun Thayyibatun Wa Rabbun Ghafur".

Muhammadiyah memilih perjuangan dalam kehidupan berbangsa dan bernegara melalui usaha-usaha pembinaan atau pemberdayaan masyarakat guna terwujudnya masyarakat madani (civil society) yang kuat sebagaimana tujuan Muhammadiyah untuk mewujudkan masyarakat Islam yang sebenar-benarnya. Sedangkan hal-hal yang berkaitan dengan kebijakan-kebijakan kenegaraan sebagai proses dan hasil dari fungsi politik pemerintahan akan ditempuh melalui pendekatan-pendekatan secara tepat dan bijaksana sesuai prinsip-prinsip perjuangan kelompok kepentingan yang efektif dalam kehidupan negara yang demokratis. 
Muhammadiyah mendorong secara kritis atas perjuangan politik yang bersifat praktis atau berorientasi pada kekuasaan (real politics) untuk dijalankan oleh partai-partai politik dan lembaga-lembaga formal kenegaraan dengan sebaik-baiknya menuju terciptanya sistem politik yang demokratis dan berkeadaban sesuai dengan cita-cita luhur bangsa dan negara. Dalam hal ini perjuangan politik yang dilakukan oleh kekuatan-kekuatan politik hendaknya benarbenar mengedepankan kepentingan rakyat dan tegaknya nilainilai utama sebagaimana yang menjadi semangat dasar dan tujuan didirikannya negara Republik Indonesia yang diproklamasikan tahun 1945.

Muhammadiyah senantiasa memainkan peranan politiknya sebagai wujud dari dakwah amar ma'ruf nahi munkar dengan jalan mempengaruhi proses dan kebijakan negara agar tetap berjalan sesuai dengan konstitusi dan cita-cita luhur bangsa. Muhammadiyah secara aktif menjadi kekuatan perekat bangsa dan berfungsi sebagai wahana pendidikan politik yang sehat menuju kehidupan nasional yang damai dan berkeadaban.

Muhammadiyah tidak berafiliasi dan tidak mempunyai hubungan organisatoris dengan kekuatan-kekuatan politik atau organisasi manapun. Muhammadiyah senantiasa mengembangkan sikap positif dalam memandang perjuangan 
politik dan menjalankan fungsi kritik sesuai dengan prinsip amar ma'ruf nahi munkar demi tegaknya sistem politik kenegaraan yang demokratis dan berkeadaban.

Muhammadiyah memberikan kebebasan kepada setiap anggota Persyarikatan untuk menggunakan hak pilihnya dalam kehidupan politik sesuai hati nurani masing-masing. Penggunaan hak pilih tersebut harus merupakan tanggungjawab sebagai warga negara yang dilaksanakan secara rasional dan kritis, sejalan dengan misi dan kepentingan Muhammadiyah, demi kemaslahatan bangsa dan negara.

Muhammadiyah meminta kepada segenap anggotanya yang aktif dalam politik untuk benar-benar melaksanakan tugas dan kegiatan politik secara sungguh-sungguh dengan mengedepankan tanggung jawab (amanah), akhlak mulia (akhlaq al-karimah), keteladanan (uswah hasanah), dan perdamaian (ishlah). Aktifitas politik tersebut harus sejalan dengan upaya memperjuangkan misi Persyarikatan dalam melaksanakan da'wah amar ma'ruf nahi munkar.

Muhammadiyah senantiasa bekerjasama dengan pihak atau golongan mana pun berdasarkan prinsip kebajikan dan kemaslahatan, menjauhi kemudharatan, dan bertujuan untuk 
membangun kehidupan berbangsa dan bernegara ke arah yang lebih baik, maju, demokratis dan berkeadaban. ${ }^{61}$

\section{MUHAMMADIYAH SEBAGAI PENDIRI NKRI}

Muhammadiyah lahir tidak dalam situasi kosong. Ketika organisasi ini didirikan pada 1912, Indonesia masih merupakan daerah jajahan. Belanda masih menguasai Nusantara meski pada tahapan sejarah yang menuju akhir. Di awal abad kedua puluh itu kesadaran nasional mulai bangkit secara lebih sistematis, bahwa kolonialisme harus segera diusir. Hal ini ditunjukkan dengan munculnya berbagai organisasi sosialpolitik-keagamaan yang menginginkan lepas dari belenggu kolonialisme. Boedi Oetomo (1908) dan Sarekat Islam (1911) adalah pioneer dari gerakan ini yang kemudian menginspirasi munculnya organisasi sosial politik dan tokoh-tokoh pergerakan sejak dasawarsa 1920-an hingga 1940-an. ${ }^{62}$ Kemudian disusul dengan didirikannya organisasi Islam yang bergerak dalam bidang pembinaan kehidupan masyarakat melalui gerakan amar ma'ruf nahi munkar, seperti al-Irsyad, Persatuan Islam, dan Muhammadiyah. Organisasi-organisasi

\footnotetext{
${ }^{61}$ Anonymous, Manhaj Gerakan Muhammadiyah, Ideologi, Khittah, dan Langkah, dalam Khittah Muhammadiyah dalam Kehidupan Berbangsa dan Bernegara Tahun 2002 (Khittah Denpasar), (Yogyakarta, Suara Muhammadiyah, 2009), 383-388

${ }^{62}$ Bahtiar Effendy, Muhammadiyah untuk Kemanusiaan dan Peradaban, (Surabaya: Penerbit Hikmah Press, 2012), 6
} 
yang muncul di awal abad ke-20 ini menyumbangkan pengaruh yang besar bagi kemerdekaan Negara Kesatuan Republik Indonesia.

Peran Muhammadiyah dalam menegakkan NKRI sangat jelas terlihat terutama pada masa kepemimpinan Ki Bagus Hadikusumo (1942-1953) di mana kondisi sosial politik pada masa beliau berada dalam suasana transisi dari penjajah Belanda, usaha-usaha Pemerintah Kolonial Belanda unruk menjajah Indonesia kembali, dan revolusi kemerdekaan. Pada masa itu, para pemimpin Muhammadiyah banyak terlibat dalam perjuangan, sementara di tingkat bawah hampir seluruh angkatan muda Muhammadiyah terjun dalam kancah revolusi dalam berbagai laskar kerakyatan. ${ }^{63}$

Muhammadiyah melalui para pemimpinnya terlibat aktif dalam usaha-usaha kemerdekaan. Kyai Haji Mas Mansur menjadi anggota empat serangkai bersama Ir. Sukarno, Mohammad Hatta dan Ki Hajar Dewantara yang merintis prakarsa persiapan kemerdekaan Indonesia terutama dengan pemerintahan Negara Jepang. Tokoh penting Muhammadiyah lainnya Ki Bagus Hadikusumo, Prof. Kahar Mudzakir, dan Mr. Kasman Singodimedjo bersama para tokoh bangsa lainnya mengambil peran aktif dalam merumuskan prinsip dan bangunan dasar Negara Indonesia sebagaimana

${ }^{63}$ Mustafa Kamal Pasha, op. cit, 126 
keterlibatannya di Badan Persiapan Usaha Kemerdekaan Indonesia (BPUPKI) dan Panitia Persiapan Kemerdekaan Indonesia (PPKI). Ketiga tokoh itu pula bersama tokoh Islam yang lain menjadi perumus dan penandatangan lahirnya Piagam Jakarta yang menjiwai Pembukaan UUD 1945.

Panglima Besar Jenderal Soedirman selaku kader dan pimpinan Muhammadiyah membuktikan peran strategisnya dalam perjuangan kemerdekaan dan mempertahankan keabsahan Indonesia merdeka. Soedirman menjadi tokoh utama perang gerilya dan kemudian menjadi Panglima Tentara Nasional Indonesia. Insiyur Juanda adalah tokoh Muhammadiyah yang menjadi pencetus Deklarasi Juanda tahun 1957, yang menjadi tonggak eksistensi Negara Kesatuan Republik Indonesia, yang menyatukan laut ke dalam kepulauan Indonesia, sehingga Indonesia menjadi Negara yang utuh.

\section{TANGGUNGJAWAB MUHAMMADIYAH TERHADAP NKRI}

Dalam kehidupan kebangsaan, Muhammadiyah telah berkiprah melewati berbagai fase zaman yang sarat dinamika yang dihadapi dengan penuh keikhlasan dan perjuangan tanpa kenal lelah. Di era kolonial, Muhammadiyah berperan dalam pergerakan kebangkitan bangsa menuju kemerdekaan Indonesia. Menjelang dan pada awal kemerdekaan, Muhmmadiyah berperan aktif dalam meletakkan fondasi 
negara-bangsa yang berlandaskan Pacasila dan UUD 1945. Pada masa Orde Lama, Muhammadiyah istiqamah dalam memnegakkan Negara Kesatuan Republik Indonesia agar tetap berada dalam koridor konstitusi dan cita-cita kemerdekaan, disertai usaha-usaha modernisasi sosial untuk mencerdaskan kehidupan bangsa. Di era Orde Baru, Muhammadiyah terus berkiprah dengan kerja-kerja kemasyarakatan untuk memajukan kehidupan bangsa, disertai sikap hikmah dalam menghadapi situasi politik nasional. Pada era Reformasi, Muhammadiyah menjadi pilar penting masyarakat madani (civil society) dan memelopori era baru Indonesia yang demokratis, menghargai hak asasi manusia, berwawasan kemajemukan, serta bersikap responsif dan kritis kepada pemerintah sesuai dengan kepribadian Muhammadiyah. ${ }^{64}$

Dalam kiprah kebangsaan yang penuh dinamika itulah, Muhammadiyah beserta elemen umat Islam lainnya telah ikut meletakkan dasar konstitusi dan orientasi politik islam yang berbasis moral dan berwawasan kebangsaan, di samping karya nyata Muhammadiyah lainnya di bidang pemikiran, pendidikan, dan kepedulian sosial.

Kini Muhammadiyah dihadapkan pada kehidupan keumatan, kebangsaan, dan kemanusiaan universal yang

\footnotetext{
${ }^{64}$ Haedar Nashir, Memahami Ideologi Muhammadiyah, (Yogyakarta:
} Suara Muhammadiyah, 2016), 227 
berada dalam pertaruhan yang krusial karena dilanda berbagai persoalan yang dilematik. Bahwa umat islam Indonesia sebagai penduduk terbesar masih menghadapi masalah rendahnya kualitas sumber daya manusia, kemiskinan, ketertinggalan, dan keterbelakangan dalam banyak aspek kehidupan, baik di bidang politik, ekonomi, sosial budaya, kemanusiaan, serta terorisme. Di tengah masalah bangsa yang sangat kompleks tersebut, Muhammadiyah berkomitmen kuat untuk menjadi bagian dari penyelesai masalah (problem solver) dengan mengambil prakarsa, partisipasi, dan langkah yang proaktif dan strategis melalui gerakan pencerahan bagi kehidupan umat, bangsa, dan kemanusiaan universal.

E. BENTUK DAN MODEL PERAN KEBANGSAAN MUHAMMADIYAH

Muhammadiyah berpandangan bahwa berkiprah dalam kehidupan bangsa dan negara merupakan salah satu perwujudan dari misi dan fungsi melaksanakan da'wah amar ma'ruf nahi munkar sebagaimana telah menjadi panggilan sejarahnya sejak zaman pergerakan hingga masa awal dan setelah kemerdekaan Indonesia. Peran dalam kehidupan bangsa dan negara tersebut diwujudkan dalam langkahlangkah strategis dan taktis sesuai kepribadian, keyakinan dan cita-cita hidup, serta khittah perjuangannya sebagai acuan 
gerakan sebagai wujud komitmen dan tanggungjawab dalam mewujudkan "Baldatun Thoyyibatun Wa Rabbun Ghafur".

Peran dalam kehidupan berbangsa dan bernegara dapat dilakukan melalui dua strategi dan lapangan perjuangan. Pertama, melalui kegiatan-kegiatan politik yang berorientasi pada perjuangan kekuasaan/kenegaraan (real politics, politik praktis) sebagaimana dilakukan oleh partai-partai politik atau kekuatan-kekuatan politik formal di tingkat kelembagaan negara. Kedua, melalui kegiatan-kegiatan kemasyarakatan yang bersifat pembinaan atau pemberdayaan masyarakat maupun kegiatan-kegiatan politik tidak langsung (high politics) yang bersifat mempengaruhi kebijakan negara dengan perjuangan moral (moral force) untuk mewujudkan kehidupan yang lebih baik di tingkat masyarakat dan negara sebagaimana dilakukan oleh kelompok-kelompok kepentingan (interest groups).

Adapun Muhammadiyah secara khusus menempatkan peran kebangsaannya pada beberapa hal:

1. Mengambil peran dalam lapangan kemasyarakatan yang mengarah kepada pemberdayaan masyarakat. Hal ini dinilai Muhammadiyah tidak kalah penting dan strategis daripada aspek perjuangan politik kekuasaan. Perjuangan di lapangan kemasyarakatan diarahkan untuk terbentuknya masyarakat utama atau masyarakat madani 
(civil society) sebagai pilar utama terbentuknya negara yang berkedaulatan rakyat.

2. Muhammadiyah sebagai organisasi sosial-keagamaan (organisasi kemasyarakatan) yang mengemban misi da'wah amar ma'ruf nahi munkar senantiasa bersikap aktif dan konstruktif dalam usaha-usaha pembangunan dan reformasi nasional sesuai dengan khittah (garis) perjuangannya serta tidak akan tinggal diam dalam menghadapi kondisi-kondisi kritis yang dialami oleh bangsa dan negara. Karena itu, Muhammadiyah senantiasa terpanggil untuk berkiprah dalam kehidupan berbangsa dan bernegara dengan berdasarkan pada khittah perjuangan

3. Menyerukan kepada warga Muhammadiyah untuk mengambil bagian dan tidak boleh apatis (masa bodoh) dalam kehidupan politik, melalui berbagai saluran secara positif,seperti berpartisipasi aktif dalam Pemilihan Umum, sebagai wujud bermuamalah dengan tetap mengedepankan prinsip etika/akhlak Islam dengan tujuan membangun masyarakat Islam yang sebenar-benarnya.

4. Meminta para politisi Muhammadiyah untuk menunjukkan keteladanan diri yang benar, jujur, dan adil serta menjauhkan diri dari perilaku politik yang kotor, membawa kerusakan, dan hanya mementingkan diri 
sendiri. Berpolitik dengan keshalihan, sikap positif dan memiliki cita-cita bagi terwujudnya masyarakat Islam yang sebenar-benarnya, dengan fungsi amar ma'ruf nahi munkar

5. Menggalang silaturrahim dan ukhuwah dengan berbagai elemen bangsa ${ }^{65}$ guna memobilisasi seluruh potensi yang dimiliki dan memerankan fungsi-fungsi keormasan secara optimal baik dalam penguatan masyarakat madaniyah maupun dalam mempercepat kemajuan bangsa secara keseluruhan

Dan orang-orang yang berjihad untuk (mencari keridhaan) Kami, benar- benar akan Kami tunjukkan kepada mereka jalanjalan Kami. Dan sesungguhnya Allah benar-benar beserta orang-orang yang berbuat baik (QS Al-Ankabut [29]: 69)

${ }^{65}$ Asymuni Abdurrahman, dkk., Pedoman Hidup Islami Warga Muhammadiyah, (Yogyakarta: Suara Muhammadiyah, 2009), 87-89 


\section{F. RANGKUMAN}

1. Muhammadiyah dalam menjalankan perannya kepada negara mengacu pada Khittah Denpasar tahun 2002 yaitu Khittah dalam Kehidupan Berbangsa dan Bernegara dengan tujuan untuk terwujudnya "Baldatun Thayyibatun Wa Rabbun Ghafur".

2. Muhammadiyah memilih perjuangan dalam kehidupan berbangsa dan bernegara melalui usahausaha pembinaan atau pemberdayaan masyarakat tidak melalui politik praktis.

3. Muhammadiyah menegaskan bahwa dirinya tidak berafiliasi dan tidak mempunyai hubungan organisatoris dengan kekuatan-kekuatan politik atau organisasi manapun. Namun Muhammadiyah tetap memberikan kebebasan kepada setiap anggota Persyarikatan untuk menggunakan hak pilihnya dan berperan aktif dalam politik sesuai hati nurani masingmasing.

4. Peran Muhammadiyah dalam menegakkan NKRI sangat jelas terlihat terutama pada masa kepemimpinan Ki Bagus Hadikusumo (1942-1953), baik peran para pemimpin Muhammadiyah yang banyak terlibat dalam perjuangan, maupun pemikiran 
dan gerakan yang mendorong upaya-upaya kemerdekaan.

5. Mulai era kolonial ketika Muhammadiyah didirikan sampai era reformasi, Muhammadiyah selalu mengambil peran dalam meningkatkan kehidupan bangsa dan negara sebagai wujud tanggung jawab kepada NKRI.

6. Peran dalam kehidupan berbangsa dan bernegara dilakukan melalui kegiatan-kegiatan kemasyarakatan yang bersifat pembinaan atau pemberdayaan masyarakat maupun kegiatan-kegiatan politik tidak langsung (high politics) yang bersifat mempengaruhi kebijakan negara dengan perjuangan moral (moral force) untuk mewujudkan kehidupan yang lebih baik di tingkat masyarakat dan negara.

\section{G. LATIHAN SOAL}

1. Jelaskan khittah Muhammadiyah dalam kehidupan berbangsa dan bernegara

2. Bagaimanakah peran Muhammadiyah dalam mendirikan NKRI?

3. Jelaskan sikap dan peran Muhammadiyah dalam bidang politik negara 
4. Mengapa Muhammadiyah memilih untuk tidak masuk dalam dunia politik praktis?

5. Jelaskan tanggung jawab Muhammadiyah dalam pembangunan bangsa dan negara.

\section{H. REFERENSI}

Anonymous. Manhaj Gerakan Muhammadiyah, Ideologi, Khittah, dan Langkah, dalam Khittah Muhammadiyah dalam Kehidupan Berbangsa dan Bernegara Tahun 2002 (Khittah Denpasar. Yogyakarta: Suara Muhammadiyah, 2009

Effendy, Bahtiar. Muhammadiyah untuk Kemanusiaan dan Peradaban. Surabaya: Penerbit Hikmah Press. 2012

Nashir, Haedar. Memahami Ideologi Muhammadiyah. Yogyakarta: Suara Muhammadiyah, 2016

Abdurrahman, Asymuni dkk.. Pedoman Hidup Islami Warga Muhammadiyah. Yogyakarta: Suara Muhammadiyah, 2009

Pasha, Musthafa Kamal \& Ahmad Adaby Darban. Muhammadiyah Sebagai Gerakan Islam. Yogyakarta: Pustaka SM. 2009 


\section{BIODATA PENULIS}

Puspita Handayani, lahir di Sidoarjo, Jawa

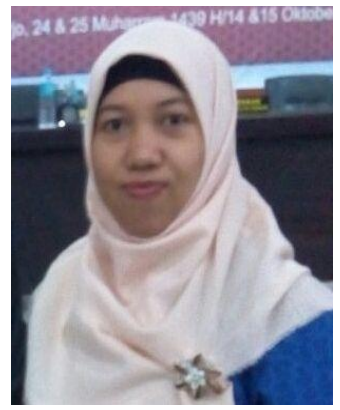

Timur pada tanggal 20 Juli 1079. Merupakan dosen Al-Islam dan Kemuhammadiyahan (AIK) di Fakultas Ekonomi dan Bisnis UMSIDA. Gelar S.Ag diperoleh dari fakultas Ushuluddin IAIN Sunan Ampel Surabaya (UINSA sekaranga) lulus tahun 2001, dilanjutkan Magister Pendidikan Agama Islam di almamater yang sama lulus pada tahun 2010. Pada tahun 2016 menulis buku ajar AIK4 bidang Ekonomi, serta melakukan penelitian tentang Aisyiyah dan Ekonomi Kreatif Upaya Pemberdayaan Perempuan Melalui Bina Ekonomi Keluarga di Kecamatan Tanggulangin yang dipublikasikan pada Prosiding dan Semnas Fakultas Ekonomi dan Bisnis UMSIDA. Pada tahun yang sama memlakukan penelitian tentang Pengaruh Pendidikan Karakter Mahasiswa Universitas Muhammadiyah Sidoarjo (PKMU) Terhadap Perilaku Mahasiswa Fakultas Ekonomi dan Bisnis.

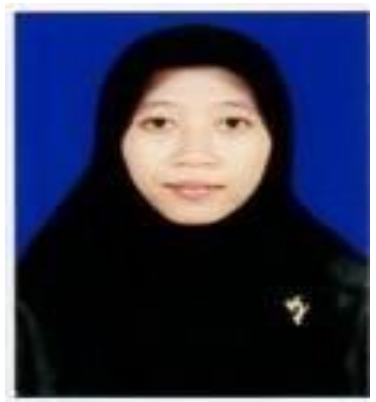

Ima Faizah, , lahir di Sidoarjo, Jawa Timur pada tanggal 19 Agustus 1980 Merupakan dosen Al-Islam dan Kemuhammadiyahan (AIK) di Fakultas Ekonomi dan Bisnis UMSIDA. Mendapat gelar Magister Pendidikan Islam (M.Pd.I). penulis juga sebagai pembimbing Mahasiswa UMSIDA pada Pengabdian Masyarakat $(\mathrm{KKN})$ di Desa Gang gang Panjang Kecamatan Tanggulangin. 
